JULIANO VENTURA PINTO

\title{
AVALIAÇÃO DA PRESENÇA DE FATOR XI DE COAGULAÇÃO EM PREPARAÇÕES DE IMUNOGLOBULINA G PARA USO INTRAVENOSO
}

Dissertação apresentada ao Programa de PósGraduação Interunidades em Biotecnologia USP/Instituto Butantan/IPT, para obtenção do Título de Mestre em Biotecnologia.

São Paulo

2014 


\section{AVALIAÇÃO DA PRESENÇA DE FATOR XI DE COAGULAÇÃO EM PREPARAÇÕES DE IMUNOGLOBULINA G PARA USO INTRAVENOSO}

Dissertação apresentada ao Programa de PósGraduação Interunidades em Biotecnologia USP/Instituto Butantan/IPT, para obtenção do Título de Mestre em Biotecnologia.

Área de concentração: Biotecnologia

Orientadora:

Prof. Dra. Elizabeth Angelica Leme Martins

Versão original 
DADOS DE CATALOGAÇÃO NA PUBLICAÇÃO (CIP)

Serviço de Biblioteca e Informação Biomédica do

Instituto de Ciências Biomédicas da Universidade de São Paulo

(c) reprodução total

Pinto, Juliano Ventura.

Avaliação da presença de Fator XI de coagulação em preparações de imunoglobulina G para uso intravenoso / Juliano Ventura Pinto. -São Paulo, 2014.

Orientador: Profa. Dra. Elizabeth Angélica Leme Martins.

Dissertação (Mestrado) - Universidade de São Paulo. Instituto de Ciências Biomédicas. Programa de Pós-Graduação Interunidades em Biotecnologia USP/IPT/Instituto Butantan. Área de concentração: Biotecnologia. Linha de pesquisa: Purificação de hemoderivados.

Versão do título para o inglês: Evaluation of the presence of coagulation Factor $\mathrm{XI}$ in intravenous immunoglobulin $\mathrm{G}$ preparasitons.

1. Hemoderivados 2. IgG 3. FXI 4. Efeitos Tromboembólicos 5. aTTP 6. Cromogênico I. Martins, Profa. Dra. Elizabeth Angélica Leme II. Universidade de São Paulo. Instituto de Ciências Biomédicas. Programa de Pós-Graduação Interunidades em Biotecnologia USP/IPT/Instituto Butantan III. Título. 
UNIVERSIDADE DE SÃO PAULO

Programa de Pós-Graduação Interunidades em Biotecnologia

Universidade de São Paulo, Instituto Butantan, Instituto de Pesquisas Tecnológicas

Candidato(a): $\quad$ Juliano Ventura Pinto.

Título da Dissertação: $\quad$ Avaliação da presença de Fator XI de coagulação em preparações de imunoglobulina $G$ para uso intravenoso.

Orientador(a): $\quad$ Profa. Dra. Elizabeth Angélica Leme Martins.

A Comissão Julgadora dos trabalhos de Defesa da Dissertação de Mestrado, em sessão pública realizada a . considerou
( ) Aprovado(a)
( ) Reprovado(a)

Examinador(a): Assinatura:

Nome:

Instituição:

Examinador(a): Assinatura:

Nome:

Instituição:

Presidente: Assinatura:

Nome:

Instituição: 


\section{COMISSÃO DE ÉTICA NO USO DE ANIMAIS \\ INSTITUTO BUTANTAN}

Av. Dr. Vital Brasil, 1500, CEP 05503-900, São Paulo, SP, Brasil

Telefone: (55) (011) 2627-9585 - Fax: (55) (011) 2627-9505

ceuaib@butantan.gov.br

São Paulo, 12 de dezembro de 2013

\section{CERTIFICADO}

Certificamos que o projeto "Avaliação da presença de fator XI de coagulação em preparações de imunoglobulina", protocolo $\mathrm{n}^{\circ}$. I-1176/13, sob a responsabilidade de Elizabeth Angélica Leme Martins e Juliano Ventura Pinto, não envolve a criação e/ou utilização de animais pertencentes ao filo Chordata, subfilo Vertebrata, para fins de pesquisa científica.

This is to certify that the proposal "Evaluation of the presence of coagulation factor XI in immune globulin G preparations for intravenous use", protocol $n^{\circ} \mathrm{I}-1176 / 13$, under the responsibility of Elizabeth Angelica Leme Martins and Juliano Ventura Pinto, has been reviewed by the Institute Butantan Animal Care and Use Committee, and that it does not involve breeding and/or use of animals belonging to phylum Chordata, subphylum Vertebrata, in scientific research.

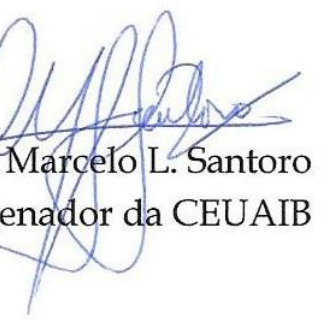


Dedico este trabalho aos meus pais,

Paulo e Beth pelo apoio incondicional. 


\section{AGRADECIMENTOS}

À Dra. Elizabeth Angélica Leme Martins, pelo crédito concedido, pela ajuda em incontáveis momentos, por ser amiga e exemplo. Beth, você é admirada por muitas pessoas, posso dizer firmemente que sou uma delas.

À Dra. Elizabeth Cheng pelos diversos conselhos e ajudas no laboratório.

Ao Dr. Alexandre Yague Lopes por discutir e aconselhar.

Ao Dr. Benedito Carlos Prezoto, pela grande ajuda nesse trabalho.

À Dra. Mickie Takagi e Dra. Giovana Cappio Barazzone pelos conselhos, correções e dicas.

À Dra. Erika Nakajima por me ajudar tanto e sempre fazer isso com amor, além de ser minha grande amiga por longa data.

À doutoranda Cláudia Iwashita Verinaud, além da amizade, esta sempre disposta a ajudar, conversar e aconselhar.

À Sueli, Sr. Jô e Ronaldo pelo apoio no laboratório, amizade e risadas.

Ao pessoal do laboratório Gabriel, luri, Marina e Flávia pela amizade e ajuda.

À Daniela Jinzengi pela ajuda e por sempre estar por perto.

Ao pessoal da secretaria de biotecnologia Marcos e Fábia pela ajuda.

À Tereza e Renata da biblioteca do ICB pela ajuda e simpatia.

À minha namorada Fernanda pelo apoio, ajuda, paciência e grande entendimento. Obrigado Fefa.

À Mônica, que apesar de não estar mais presente, apoiou minhas decisões e sempre foi uma grande amiga.

À minha família por nunca desistir e sempre realizar justiça em seus atos, o que se tornou meu objetivo de vida. 
Não se mede o valor de um homem pelas suas roupas ou pelos bens que possui,

o verdadeiro valor do homem é o seu caráter, suas ideias e a nobreza dos seus ideais.

\section{Charles Chaplin}

A alegria está na luta, na tentativa, no sofrimento envolvido e não na vitória propriamente dita.

Mahatma Gandhi 


\section{RESUMO}

PINTO, J. V. Avaliação da presença de Fator XI de coagulação em preparações de imunoglobulina G para uso intravenoso. 2014. 93 f. Dissertação (Mestrado em Biotecnologia) - Programa de Pós Graduação Interunidades em Biotecnologia, USP/Instituto Butantan/IPT, São Paulo, São Paulo, 2014.

A disponibilidade de biofármacos derivados de plasma sanguíneo é um parâmetro importante para medir a qualidade da saúde em um país. Dentre os produtos hemoderivados, concentrados de imunoglobulinas tem alto valor agregado, pois são prescritos para muitas doenças. Para que as preparações de imunoglobulinas sejam efetivas, é importante que as populações recebam o produto derivado de plasma de doadores da mesma região. Além disso, estão previstos novas aplicações, tornando o produto muito competitivo e tornando imprescindível a busca por autossuficiência. Os hemoderivados são produtos muito caros e a capacidade de fracionamento de plasma é uma marca de desenvolvimento do país. O Instituto Butantan, por sua vocação em saúde publica, tem por objetivo o estabelecimento de uma planta industrial para fracionamento de plasma. Nesse contexto foi desenhado um processo produtivo moderno, baseado principalmente em cromatografias, diferente dos processos comumente usados de fracionamento por precipitações a frio em presença de etanol. Nos últimos anos foram notificados eventos tromboembólicos em pacientes que receberam infusões de concentrados de imunoglobulinas por via intravenosa ( $\mathrm{lgIV}$ ). Esses efeitos colaterais foram relacionados com presença de Fator XI de coagulação (FXI) como contaminantes nas preparações de IgIVs. Na dissertação aqui apresentada, nosso objetivo era o de rastrear o FXI nas frações cromatográficas do processo de obtenção de IgIV desenhado para a planta industrial do Instituto Butantan. O processo cromatográfico de plasma foi testado em escala piloto e o FXI foi dosado nas frações iniciais e no produto final IgIV. Uma variante do processo cromatográfico, utilizando cromatografia direta de plasma em resina de troca iônica Q-Sepharose, também foi estudada. Foram estabelecidos os métodos de dosagem de atividade de FXI por tempo de coagulação (tempo de tromboplastina parcial ativada - aPTT), e ensaio amidolítico, usando substrato cromogênico. Além disso, foram utilizados ensaios de western blot para precisar o tamanho das proteínas detectadas. Concluímos que o FXI elui juntamente com lgG nas etapas iniciais dos processos cromatográficos 
utilizados. Verificamos que ocorre a presença de FXI nos produtos finais, porém os testes devem ser reproduzidos com maior precisão, sendo que as atividades estão no limite de detecção do ensaio. Este trabalho contribui para o desenvolvimento do conjunto de testes de controle de qualidade de biofármacos derivados de plasma humano.

Palavras-chave: Hemoderivados. IgG. FXI, efeitos tromboembólicos. aTTP. Cromogênico. 


\begin{abstract}
PINTO, J. V. Evaluation of the coagulation factor $\mathrm{XI}$ presence in intravenous immunoglobulin G preparations. 2014. 93 f. Dissertation (Master in Biotechnology) - Programa de Pós Graduação Interunidades em Biotecnologia, USP/Instituto Butantan/IPT, São Paulo, São Paulo, 2014.
\end{abstract}

The availability of biopharmaceuticals derivatives from blood plasma is an important parameter to measure a country's health quality. Among hemoderivatives products, immunoglobulin concentrates have high value, being described to many diseases. For the immunoglobulin preparations to be effective, it is important for the population to receive a plasma derivative product from donors from the same region. There are also previsions for new applications, the product is becoming too competitive and the pursuit for self-sufficiency is turning to be indispensable. Hemoderivatives are very expensive products and the plasma fractionation capacity is a development trade from a country. Instituto Butantan, for its vocation in public health, aims the establishment of an industrial plant for plasma fractionation. In this context, a modern productive process was drawn, based mainly in chromatographies, which differs itself from the commonly used processes, based fractioning by cold precipitations in the presence of ethanol. In the last years, thromboembolic events were notified in patients that received infusions of intravenous immunoglobulins concentrates (IVIg). These collateral effects have been related with the presence of coagulation Factor $\mathrm{XI}(\mathrm{FXI})$ as contaminant in the IVIG preparations. In the dissertation here presented, our objective was to track FXI in the chromatographic fractions of the process of obtainment of IVIG, drawn for the industrial plant of Instituto Butantan. The plasma chromatographic process was tested in pilot scale and the FXI was measured in the initial fractions and in the final product IVIg. One variant of the chromatographic process, using direct chromatography in Q-Sepharose ionic exchange resin was also studied. The methods of measurement of FXI activity thru coagulation time (activated partial thromboplastin time - aTTP) and amidolityc assay using chromogenic substrate were established. Also, western blot assays were used to precise the size of the detected proteins. We have concluded that FXI eluates together with $\lg G$ in the early stages of the chromatographic processes used. We have verified that FXI presence occurs in the final products, however the tests have to be reproduced with more precision, 
minding that the activities are in the limit of detection of the assay. This wor contributes to the development of the set of quality control tests of biopharmaceuticals derivatives from human plasma.

Keywords: Hemoderivatives. IgG. FXI. thromboembolic effects. aTTP. Chromogenic. 


\section{LISTA DE ILUSTRAÇÕES}

Figura 1 - Mercado de produtos de fracionamento de plasma em 2008 29

Figura 2 - Esquema geral do fracionamento de plasma na planta de

hemoderivados do Instituto Butantan proposto em 2010 .32

Figura 3 - Reações das proteases na cascata de coagulação do plasma....... 35

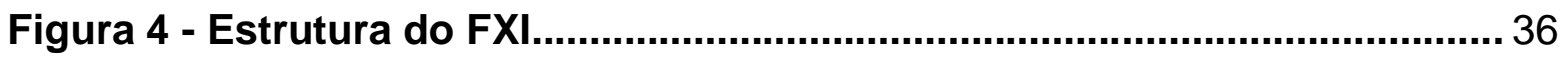

Figura 5 - Fluxograma dos processos cromatográficos do plasma em escala de bancada e cromatografia direta de plasma em coluna $Q$ Sepharose. 46

Figura 6 - Esquema do processo cromatográfico Integral e Parcial para purificação de IgG a partir de plasma humano.

Figura 7 - Cromatograma do processo de gel filtração de plasma em resina

Sepharose 4FF. 56

Figura 8 -Cromatograma do processo de troca iônica da fração F3-4FF em resina DEAE Sepharose

Figura 9 - Cromatograma da dessalinização da fração F1-DEAE concentrada, por gel filtração em resina Sephadex G25.

Figura 10 - Cromatograma do processo de troca iônica do sobrenadante recuperado da precipitação de euglobulina em resina DEAE Sepharose....... 58 Figura 11 - Cromatograma do processo de troca iônica de F1-DEAE2 em resina Q Sepharose 59

Figura 12 - Cromatograma do processo de troca catiônica da fração F1-Q em resina CM Sepharose, para remoção dos agentes de desinfecção viral. 60

Figura 13 - Perfil proteico de amostras das formulações finais de lgG.

Figura 14 - Cromatograma (UV $280 \mathrm{~nm}$ ) representativo da separação de proteínas de plasma humano em resina Sepharose 4FF.

Figura 15 - Cromatograma (UV $280 \mathrm{~nm}$ ) da separação de proteínas da fração F3-4FF em resina DEAE-Sepharose. 63

Figura 16 - Analise do perfil proteico das frações das cromatografias de plasma em Sepharose 4FF e de F3-4FF em coluna de DEAE-Sepharose, por SDS-PAGE.

Figura 17 - Análise da presença de FXI em frações de cromatografia por

Western blot.

Figura 18 - Dosagem de FXI por tempo de coagulação (aPTT) em amostras de 
plasma normal em diferentes diluições.

Figura 19 - Relação entre tempo de coagulação e concentração de plasma normal

Figura 20 - Atividade de FXI nas frações da cromatografia de plasma em resina Sepharose 4FF e DEAE Sepharose.

Figura 21 - Cromatogramas da separação de plasma em resina $Q$

Sepharose

Figura 22 - Atividade de FXI dosada por tempo de coagulação (aPTT) em amostras das frações cromatográficas de e plasma em resina Q.Sepharose.77 Figura 23 - Dosagem de FXI por método cromogênico .78

Figura 24 - Curva padrão estabelecida com os coefiencies angulares das curvas de cinetica $\Delta A b s / \Delta t$ em função da porcentagem de plasma.

Figura 25 - Dosagem de FXI por método cromogênico em frações da cromatografia de plasma em resina Q-Sepharose 79

Figura 26 - Dosagem de FXI por método cromogênico. 81

Figura 27 - Detecção de FXI em amostras de frações de cromatografia de plasma, por western blot. 


\section{LISTA DE TABELAS}

Tabela I - Volumes das frações das duas cromatografias: plasma em Sepharose 4FF e fração F3-FF em resina DEAE............................................ 64 Tabela II - Tempos de coagulação do plasma humano sem heparina, medidos em leitor de ELISA. ..70

Tabela III - Tempos de coagulação de amostras das frações cromatográficas das preparações de IgG (lotes piloto) medidos em leitor de ELISA................. 71 Tabela IV - Dosagem de FXI, lotes de preparação de IgG no Laboratório

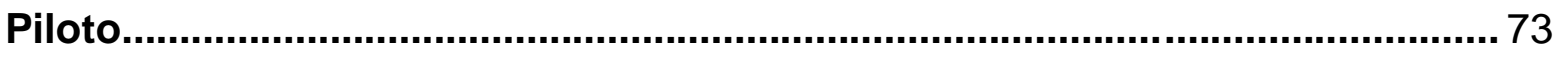

Tabela V - Atividade de FXI em frações cromatográficas de plasma em Q.Sepharose usando o plasma em pH 6 e pH 7 .............................................. 80 


\section{LISTA DE ABREVIATURAS E SIGLAS}

- A1PI - Alpha-1 indibidor de protease

- AAT - Alpha-1 antitripsina

- Abs - Absorbância

- AT-III - Antitrombina III

- aPTT - Activated partial thromboplastin time

- BMT - Transplante de medula óssea

- $\mathrm{C} 1-\mathrm{INH}$ - Inibidor $\mathrm{C} 1$ de esterase

- CAM - Cininogênio de alta massa molecular

- CIDP - Poli Neuropatia Crônica Inflamatória Desmielinizante

- CLL - Leucemia Crônica Linfocítica

- $\mathrm{cm} / \mathrm{h}$ - centímetros por hora

- Cond. - Condutividade

- COPD - Doença de obstrução crônica pulmonária

- CTI - Corn trypsin inhibitor, inibidor de tripsina de soja

- ${ }^{\circ} \mathrm{C}$ - Grau Celsius

- Da - Dalton

- DO - Densidade óptica

- ECL - Enhancer chemioluminescent

- EDTA - Ácido etileno diamino tetra-acético

- ELISA - Enzyme linked immunosorbent assay

- EUA - Estados Unidos da América

- fg. - Figura

- FII - Fator de coagulação II

- Flla - Fator de coagulação II ativado

- FV - Fator de coagulação V

- FVa - Fator de coagulação $V$ ativado

- FVII - Fator de coagulação VII

- FVIla - Fator de coagulação VII ativado

- FVIII - Fator de coagulação VIII

- FVIIla - Fator de coagulação VIII ativado 
- FIX - Fator de coagulação IX

- FIXa - Fator de coagulação IX ativado

- FX - Fator de coagulação X

- FXa - Fator de coagulação X ativado

- FXI - Fator de coagulação XI ou PTA

- FXla - Fator de coagulação XI ativado

- FXII - Fator de coagulação XII

- FXIla - Fator de coagulação XII ativado

- FXIII - Fator de coagulação XIII

- FXIIla - Fator de coagulação XIII ativado

- FDA - Administração de comidas e remédios (Órgão dos Estados Unidos da América)

- FT - Flow through - Fração de proteínas não adsorvidas na resina cromatográfica

- FvW - Fator de Von Willebrand

- g-Grama

- $\mathrm{h}$ - Hora

- HMWK - Cininogênio de alto peso molecular

- $\mathrm{HCl}$ - Ácido clorídrico

- IgM - Imonoglobunina M

- IgA - Imunoglobulina A

- IgG - Imunoglobulina G

- Igs - Imunoglobulinas

- IgIM - Imunoglobulina de uso intramuscular

- IgIV - Imunoglobulina de uso intravenoso

- IgSC - Imunoglobulina de uso subcutâneo

- ITP - Trombocitopenia Púrpura Idiopática

- KDa - Kilodalton

- L - Litros

- LFB - Laboratoire Français Du Fractionnement et des Biotechnologies

- L/h - Litro por hora

- $\mathrm{mA}$ - Milli Ampère 
- mAU - Unidade de Absorbância

- M - Molar

- mg - miligrama

- $\mathrm{mg} / \mathrm{mL}$ - miligrama por mililitro

- $\mathrm{mL}$ - Mililitros

- $\mu \mathrm{L}$ - Microlitros

- $\mathrm{mL} / \mathrm{min}$ - mililitros por minuto

- $\mu \mathrm{m}$ - micrômetro

- $\min$ - Minuto

- $\mathrm{mM}$ - Milimolar

- mm - milímetros

- MMN - Neuropatia Motora Multifocal

- $\mathrm{mS} / \mathrm{cm}$ - Millisiemens por centímetro

- $\mathrm{NaCl}$ - Cloreto de sódio

- $\mathrm{NaOH}$ - Hidróxido de sódio

- NAPTT - Tempo parcial de tromboplastina não ativada

- $\mathrm{nm}$ - Nanômetros

- NR - Nova Resina

- PBS - Salina tamponada com fosfato

- PTA - Antecedente de tromboplastina plasmática ou FXI

- PK - Pré-calicreína

- PVDF - Difluoreto de polivinilideno

- RPM - Rotações por minuto

- SDS - Doudecil sulfato de sódio

- SDS-PAGE - eletroforese em gel de poliacrilamida contendo SDS

- SID - Imunodeficiência secundária

- STI - Soy trypsin inhibitor, inibidor de tripsina de milho

- TA - Temperatura ambiente

- TBS - Solução basal - NaCl 150 mM, Tris Base 10 mM pH 7,4 e tween 0,05\%

- TEEs - Eventos tromboembólicos

- TEMED - N,N, $\mathrm{N}^{\prime}, \mathrm{N}^{\prime}$ - tetrametiletilenodiamina

- TNBP - Tributirilfosfato 
- Tris - (hidroximetil) amino-metano

- U.I - Unidade Internacional

- U.I/mL - Unidade Internacional por mililitro

- $\mu \mathrm{S} / \mathrm{cm}$ - Micro Siemens/Centímetro

- VC - volume de coluna

- Vo - V zero

- $v$ - Volts

- vWD - Doença de von Willebrand

- \% - por cento

- $\varnothing$ - Diâmetro

- - Aproximadamente 


\section{SUMÁRIO}

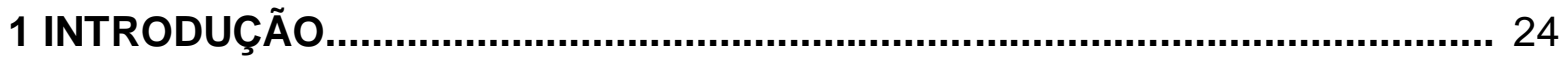

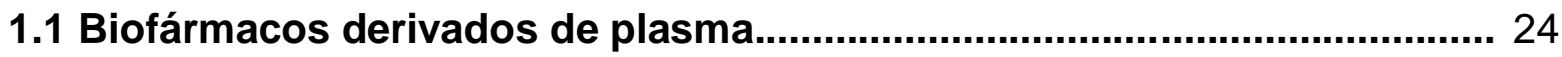

1.1.1 Fatores de coagulação............................................................................... 24

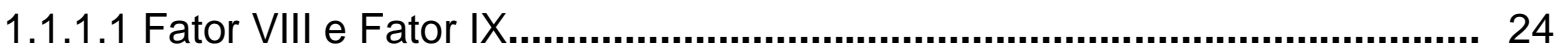

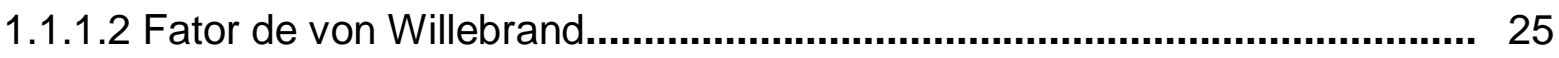

1.1.1.3 Outros fatores de coagulação............................................................. 25

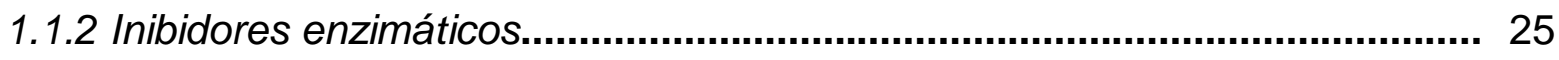

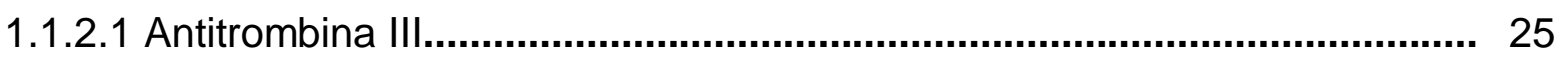

1.1.2.2 Alpha-1 antitripsina e Alpha-1 inibidor de Protease................................. 26

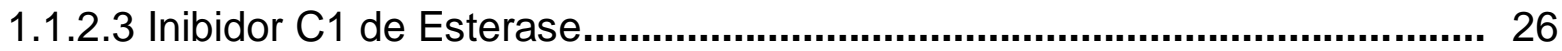

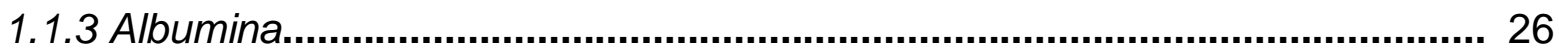

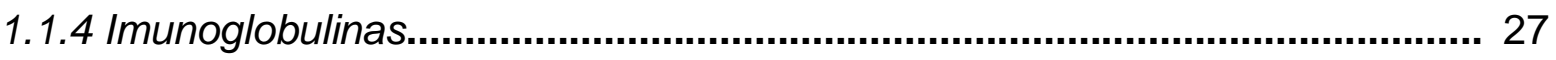

1.1.5 Produção de Imunoglobulinas polivalentes derivadas de plasma humano.... 28

1.2 Mercado de produtos derivados de plasma........................................... 28

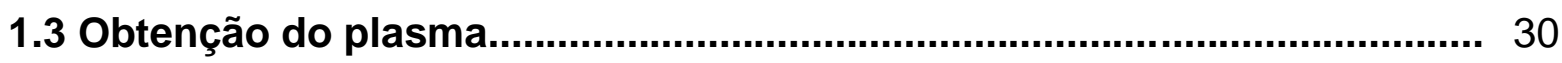

1.40 processamento do plasma............................................................... 30

1.5 A indústria de fracionamento de plasma no Brasil.................................... 31

1.5.1 Planta de fracionamento de plasma da HEMOBRÁS................................. 31

1.5.2 Planta de fracionamento de plasma do Instituto Butantan............................ 32

1.5.2.1 A planta piloto no Instituto Butantan....................................................... 33

1.6 Eventos adversos pós-infusão de IgIV - Associação com FXI

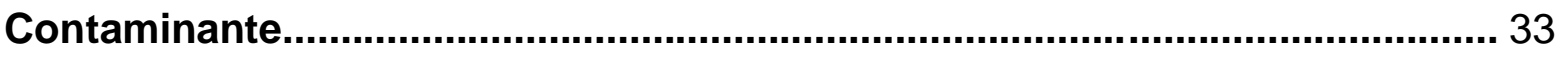

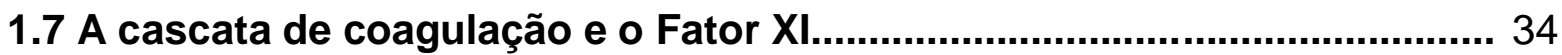

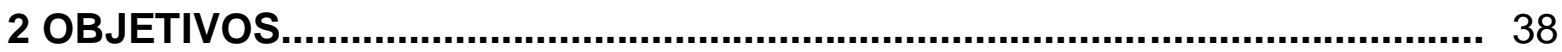

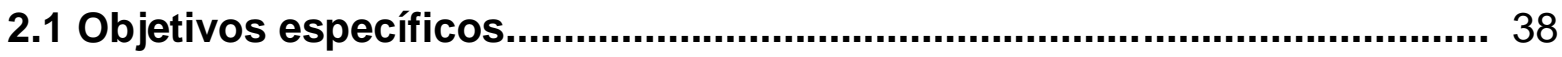

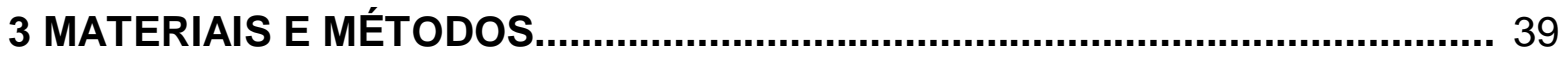

3.1 Processo cromatográfico do plasma em escala piloto............................. 39

3.1.1 Preparação do plasma humano............................................................... 39

3.1.2 Etapa 1 - Gel Filtração do plasma em resina Sepharose 4FF........................ 40

3.1.3 Etapa 2 - Cromatografia da fração F3-4FF por troca aniônica em resina DEAE Sepharose. 
3.1.4 Etapa 3 - Dessalinização da fração F1-DEAE (flow through) da cromatografia em DEAE por cromatografia em resina sephadex-G25 e ajuste de pH para precipitação de euglobulinas.

3.1.5 Etapa 4 - Separação do precipitado de euglobulinas por centrifugação contínua.

3.1.6 Etapa 5 - Cromatografia do sobrenadante da precipitação de euglobulina em resina de troca aniônica (DEAE2) para separação de albumina. 41

3.1.7 Etapa 6 - Troca aniônica da fração F1-DEAE2 em Q Sepharose. 41

3.1.8 Etapa 7 - Inativação viral da fração $F 1-Q$ e Cromatografia de troca catiônica em CM-Sepharose para eliminação dos agentes do tratamento de inativação.. 42

3.2 Processo cromatográfico do plasma em escala de bancada...................... 42

3.2.1 Preparação de plasma................................................................................... 42

3.2.2 Montagem e manutenção das colunas de cromatografia............................... 43

3.2.3 Etapa 1- Separação de proteínas de plasma por gel filtração em resina Sepharose 4FF. 43

3.2.3.1 Soluções................................................................................................ 43

3.2.3.2 Procedimento............................................................................................ 43

3.2.4 Etapa 2 - Separação por troca aniônica em resina DEAE Sepharose.......... 44

3.2.4.1 Soluções.............................................................................................. 44

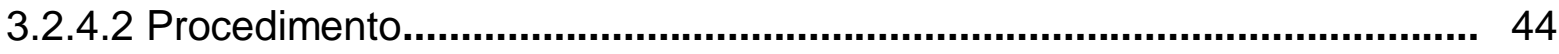

3.3 Cromatografia direta de plasma em coluna Q-Sepharose........................ 44

3.3.1 Preparo do plasma..................................................................................... 45

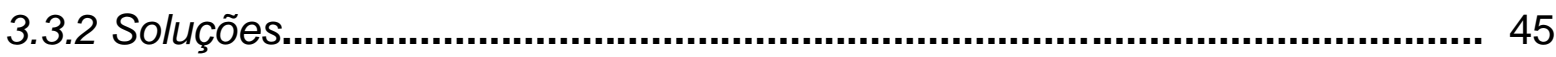

3.3.3 Procedimento............................................................................................ 45

3.4 Métodos analíticos............................................................................. 46

3.4.1 Eletroforese em gel de poliacrilamida - SDS-PAGE................................. 46

3.4.1.1 Materiais e soluções utilizadas.............................................................. 46

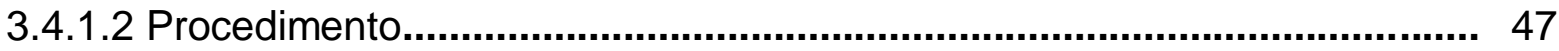

3.4.1.3 Coloração do gel com solução de Coomassie blue.................................... 47

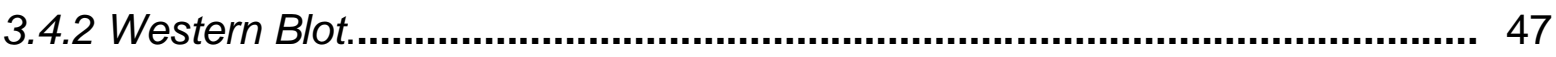

3.4.2.1 Materiais e soluções utilizadas.............................................................. 48

3.4.2.2 Procedimento........................................................................................ 48

3.4.3 Remoção de albumina de frações cromatográficas em resina Star Hypercell................................................................................................................ 49 
3.4.3.1 Preparo da coluna com resina Star Hypercell........................................ 49

3.4.3.2 Preparo do plasma.................................................................................... 49

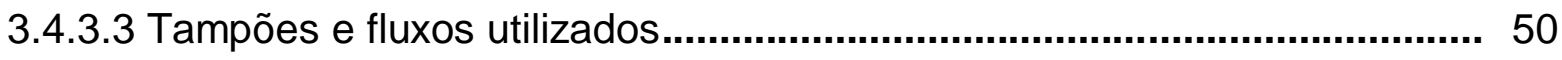

3.4.4 Dosagem de atividade FXI medindo cinética de formação do coagulo em leitor

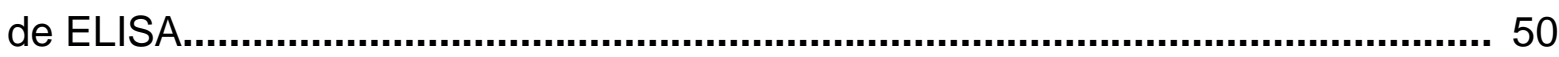

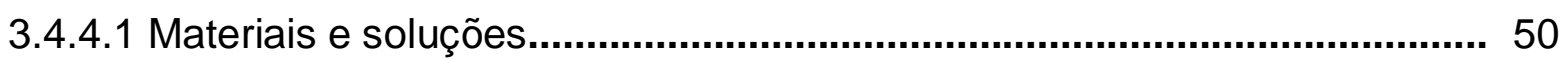

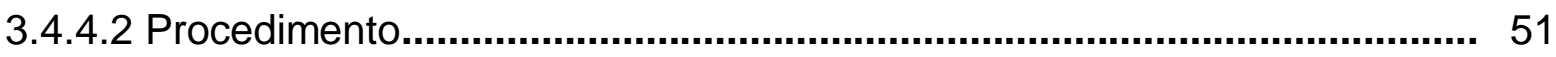

3.4.4.3 Cálculos de atividade de FXI por curva padrão com diluições de

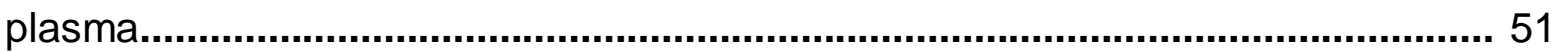

3.4.5 Dosagem de atividade de FXI por método amidolítico, com substrato

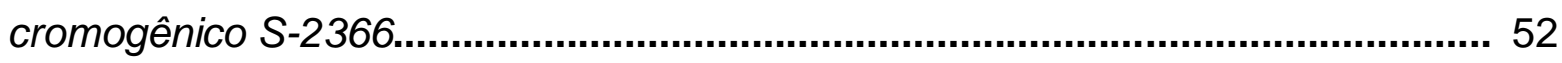

3.4.5.1 Materiais e Soluções........................................................................ 52

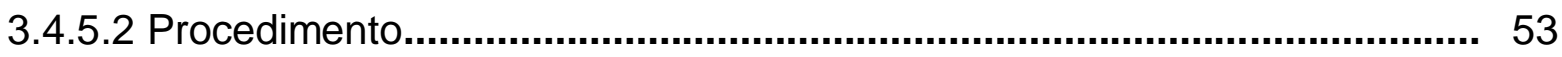

3.4.5.3 Calculo da atividade de FXI............................................................... 54

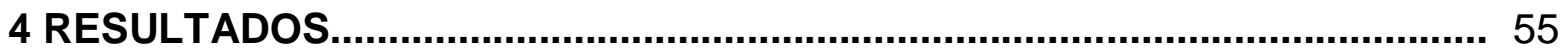

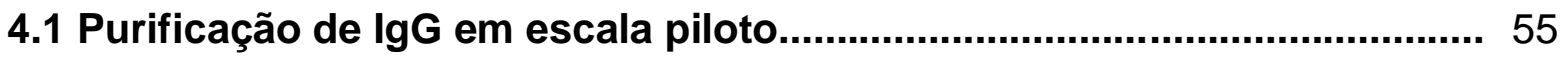

4.1.1 Etapa 1 - Cromatografia de gel filtração de plasma em resina Sepharose

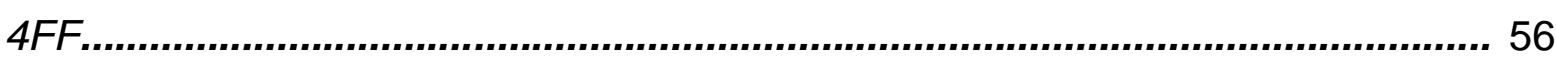

4.1.2 Etapa 2 - Cromatografia de troca aniônica............................................ 57

4.1.3 Etapa 3 - Concentração por ultrafiltração................................................. 57

4.1.4 Etapa 4 - Dessalinização por Gel Filtração, precipitação e separação de

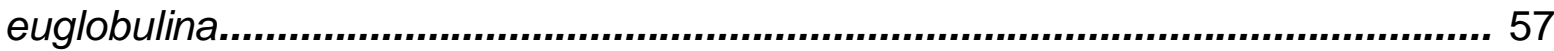

4.1.5 Etapa 5 - Cromatografia de troca aniônica para separação de albumina..... 58

4.1.6 Etapa 6 - Troca aniônica em Q Sepharose........................................... 59

4.1.7 Etapa 7 - Inativação viral e cromatografia de troca catiônica....................... 59

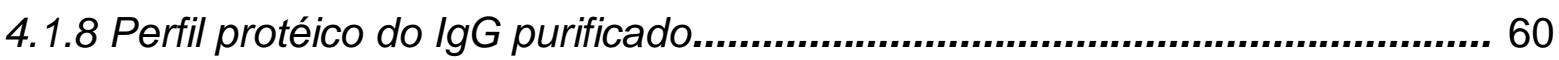

4.2 Reprodução do processo de purificação de imunoglobulinas de plasma humano em escala de bancada.................................................................... 61

4.2.1 Etapa 1 - Cromatografia de gel filtração................................................. 62

4.2.2 Segunda etapa de purificação - Cromatografia da F3-4FF em resina

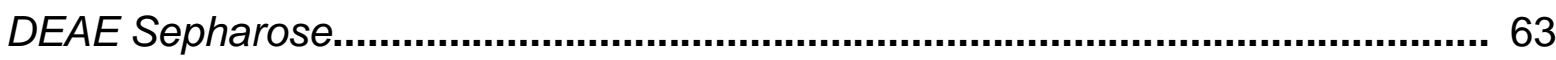

4.2.3 Análise das frações eluídas da cromatografia em resina DEAE Sepharose por

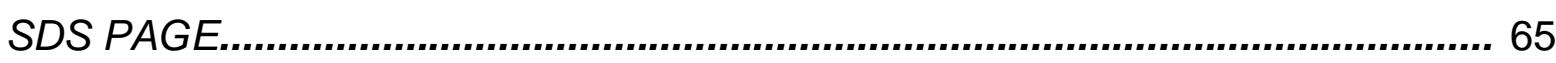


4.3 Análise da presença de FXI em amostras de IgG produzidas na planta piloto e nas frações das duas cromatografias realizadas em escala de bancada, por Western Blot. 65

4.4 Dosagem de atividade de FXI nas frações de cromatografia de plasma 68

4.5 Cromatografia Direta de plasma em Q. Sepharose. 74

4.5.1 Dosagem de atividade de FXI em amostras de Q. Sepharose por tempo de coagulação, em placas de ELISA........................................................................ 76

4.5.2 Dosagem de atividade de FXI por hidrólise de peptídeo cromogênico.......... 77 4.5.3 Avaliação da presença de FXI em frações da cromatografia de plasma em resina Q-Sepharose por western blot................................................................... 81

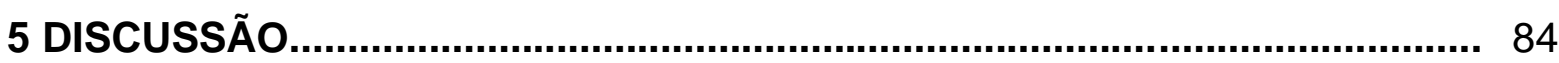

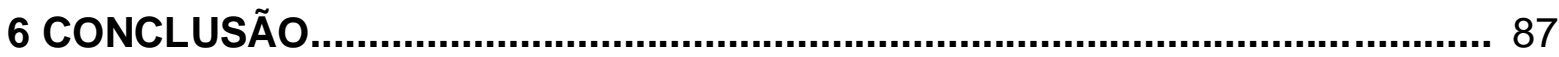

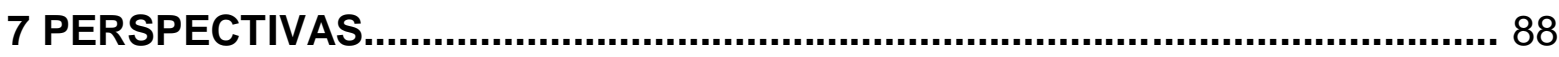

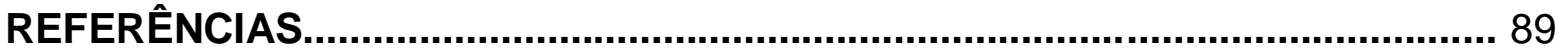




\section{INTRODUÇÃO}

\subsection{Biofármacos derivados de plasma}

O uso do plasma e suas frações têm uma história complexa, que inclui aspectos éticos, econômicos e políticos. Durante a Segunda Guerra Mundial, com a demanda de sangue para transfusão no campo de batalha, criou-se um esforço da população para doações. Tiveram início estudos mais específicos e início da produção em grande escala de proteínas do sangue, com foco em Albumina (BARANDUN et al., 1982).

Até anos atrás, a albumina era o produto hemoderivado fundamental, utilizado no tratamento do choque para recomposição do volume plasmático, para queimados e nefróticos. Hoje mais de 20 preparações terapêuticas com proteínas derivadas de plasma são comercializadas, sendo os principais produtos Imunoglobulinas, fatores de coagulação, albumina e inibidores enzimáticos (BORDIN; LANGHI JUNIOR; COVAS, 2007).

\subsubsection{Fatores de coagulação}

Os fatores de coagulação de maior importância dentre os hemoderivados comercializados são o Fator VIII (FVIII), Fator IX (FIX) e Fator de von Willebrand (FvW) e Complexo Protrombínico, dentre outros fatores e compostos utilizados em terapias para diferentes doenças de coagulação (NILSSON et al., 1994).

\subsubsection{Fator VIII e Fator IX}

Hemofilia é resultado da perda ou erro na função de proteínas da cascata de coagulação. Em conseqüência, ocorre incapacidade no controle de sangramentos a menos que se use terapia de reposição.

- Hemofilia A - Deficiência de FVIII causa Hemofilia A que pode ser branda, moderada ou severa. Pacientes moderados e severos precisam de terapia de reposição de FVIII em base regular (profilática) ou em episódios hemorrágicos ("on-demand"). 
- Hemofilia B - Deficiência de FIX causa Hemofilia B que também pode ser branda, moderada ou severa, embora não tão prevalente como a Hemofilia $A$. Essa deficiência requer reposição com concentrados de FIX (NILSSON et al., 1994).

\subsubsection{Fator de von Willebrand}

Doença de von Willebrand (DvW) é causada por falha ou disfunção de fator de von Willebrand (FvW), o qual, entre outras atividades, se liga e estabiliza o FVIII. Essa doença é mais freqüente que hemofilia, mas na maioria dos casos se manifesta de forma branda e o tratamento é leve e por um curto período de tempo. Pacientes da doença severa requerem o uso de produtos contendo FvW, o qual geralmente contem FVIII (NILSSON et al., 1994).

\subsubsection{Outros fatores de coagulação}

Existem deficiências em fatores de coagulação que podem ocorrer pontualmente, como durante cirurgias, levando a hemorragias. Nesse grupo estão Fatores II, V, VII, $\mathrm{X}, \mathrm{XI}, \mathrm{XIII}$ e fibrinogênio. Concentrados desses fatores são disponíveis para terapias.

\subsubsection{Inibidores enzimáticos}

\subsubsection{Antitrombina III}

Antitrombina III (AT-III) é um inibidor de trombina e pode ser usado em terapia de reposição em caso de deficiência da proteína. Deficiência em AT-III resulta em inabilidade para controlar adequadamente a coagulação, levando ao excesso de coagulação e risco de trombose. A deficiência congênita é rara, mas a forma adquirida pode ser desenvolvida em disfunções hepáticas, sepsis ou cirurgias maiores. AT-III pode ser usada em cirurgias como anticoagulante para pacientes que sofrem de baixos níveis de AT-III (SCHALLER et al., 2008). 


\subsubsection{Alpha-1 antitripsina e Alpha-1 inibidor de Protease}

Alpha-1 antitripsina (AAT) é um inibidor de tripsina, utilizado para reposição em caso de deficiência dessa proteína, uma desordem genética rara que resulta em uma variedade de problemas, incluindo enfisema, doença de obstrução crônica pulmonária (COPD), bronquite crônica, cirroses, hepatite neonatal e icterícia. Deficiência em AAT é encontrada principalmente entre pessoas do norte europeu e seus descendentes. Deficiência em Alpha-1 Inibidor de Protease (A1P1) tem sido reportada e resulta também em complicações pulmonares como enfisema prematuro (SCHALLER et al., 2008).

\subsubsection{Inibidor C1 de Esterase}

$\mathrm{O}$ inibidor $\mathrm{C} 1$ de Esterase (C1-INH) é usado em terapia de reposição em pacientes de Angioedema Hereditário (HAE), o qual resulta em edema da face, pescoço e extremidades das vias aéreas superiores. Se não diagnosticado, essa rara doença pode levar a inchamento da laringe e causar sufocamento. Terapias de reposição de C1-INH têm sido usadas somente nos EUA, embora seja disponibilizada comercialmente por décadas na Europa.

Vários desses biofármacos já são produzidos na forma recombinante, para complementar a demanda dos produtos plasmáticos (SCHALLER et al., 2008).

\subsubsection{Albumina}

Albumina tem sido usada desde os anos 40 como reposição de volume sanguíneo ou fluídos e manutenção da pressão oncótica em cirurgias ou em situações de trauma. Também é usada em casos de sepsis, choque séptico, terapia de troca de plasma, queimaduras, diálise renal entre outras aplicações. Em algumas dessas condições, albumina foi substituída por soluções de reposição não protéica, como solução Hetastarch, um colóide artificial derivado de amido ceroso, composto de amilopectina, solução de Ringer com lactate, solução de lactato de sódio ou salina (SCHALLER et al., 2008). 


\subsubsection{Imunoglobulinas}

Imunoglobulinas (Igs) são anticorpos produzidos no corpo por células B para identificar e ajudar a destruir agentes e moléculas estranhas, incluindo bactérias e vírus (ROITT; BROSTOFF; MALE, 2003).

As imunoglobulinas estão presentes em grande quantidade no plasma e compõem a principal função do sistema imunológico humoral no organismo. Preparações de Igs polivalentes são usadas extensivamente em terapias de reposição desde o início de sua comercialização nos anos cinqüenta. As Imunoglobulinas $G(\lg G)$ são as mais abundantes nas preparações, mas outras classes de imunoglobulinas também estão presentes, especialmente $\lg \mathrm{M}$ e $\lg \mathrm{A}$. Duas apresentações desse biofármaco são mais comercializadas: Imunoglobulinas de uso intravenoso (IgIV) e subcutâneo (IgSC) (ROITT; BROSTOFF; MALE, 2003).

Concentrados de Imunoglobulinas são prescritas na terapia de reposição para deficiência congênita de produção de anticorpos e outras condições de imunodeficiência. Recentemente, têm sido mostradas novas aplicações, por exemplo, no tratamento de condições neurológicas, doenças hematológicas e doenças infecciosas, chegando a mais de 200 indicações para uso de $\mathrm{IgIV} / \mathrm{IgSC}$. As indicações de imunoglobulinas aprovadas pelo FDA incluem: Imunodeficiência primária (PID) e secundária, Poli neuropatia Crônica Inflamatória Desmielinizante (CIDP), Trombocitopenia Púrpura Idiopática (ITP), Neuropatia Motora Multifocal (MMN), Doença de Kawasaki, Leucemia Crônica Linfocítica (CLL) e pós transplante de medula (Bone Marrow Transplant - BMT) (FARRUGIA et al., 2009).

Imunoglobulinas Hiperimunes - Preparações de imunoglobulinas hiperimunes são aquelas em que o nível de anticorpos contra um antígeno em particular está enriquecido, em oposição ao naturalmente diverso repertório de anticorpos presentes nas preparações convencionais de IgIV e IgSC. Preparações hiperimunes são obtidas a partir de plasmas de doadores vacinados com um antígeno específico ou naturalmente imunizados. Os mais comumente preparados são Anti-D (antiRhoD), anti-Citomegalovírus (CMV), anti-Hepatites A e B, anti-Raiva, anti-Tétano e anti-Varicela (FARRUGIA et al., 2009). 
Segundo dados apresentados por Burnouf (2007), novas aplicações utilizando albumina e de IgIV poderá dobrar essa necessidade, requerendo maior quantidade de plasma.

\subsubsection{Produção de Imunoglobulinas polivalentes derivadas de plasma humano}

Concentrados de IgGs usados como anticorpos terapêuticos (STIEHM; KELLER; VYAS, 2008) representam os principais produtos da indústria de fracionamento de plasma (FARRUGIA et al., 2009). Existem diversas formulações comerciais de imunoglobulinas disponíveis para uso clínico, referidas como lgs poli-específicas ou polivalentes, provenientes de diferentes fracionadores de plasma. São produzidas a partir de mistura de plasma separado do sangue de múltiplos doadores e contém milhões de moléculas de imunoglobulinas diferentes, que reflete a exposição cumulativa da população doadora ao ambiente. Portanto é importante que pacientes com imunodeficiências recebam imunoterapias com concentrados de plasma de doadores da mesma população.

Preparações de Imunoglobulina polivalente derivadas de plasma humano, quer seja para infusões intravenosas (IgIV), subcutâneas (IgSC) ou intramusculares (IgIM), são indicadas em diversas aplicações. Concentrado de Igs está na "Lista Modelo de Medicinas Essenciais da Organização Mundial de Saúde" (World Health Organization. WHO model list of essential medicines. 14th ed. Geneva: World Health Organization; 2011, http://whqlibdoc.who.int/hq/2011/a95053 eng.pdf), destacando sua importância na estratégia de cuidados em saúde prioritários para pacientes com imunodeficiência. Com atividades imuno-modulatórias, concentrado de Igs é uma terapia de primeira-linha para um número crescente de desordens inflamatórias, reumáticas e neurológicas imuno-mediadas.

\subsection{Mercado de produtos derivados de plasma}

Segundo o escritório de consultoria em indústria de fracionamento de plasma "The Marketing Reaseach Bureau, Inc" (http://marketingresearchbureau.com/), em 2010 o mercado de hemoderivados foi distribuído entre América do Norte $(36,6 \%)$, Europa (36,2\%), Ásia e regiões do Pacifico (15,3\%), América do Sul (5,3\%), Oceania $(2,6 \%)$, Oriente médio $(2,6 \%)$ e África $(0,9 \%)$. Pode se observar que os dois maiores 
consumidores, América do Norte e Europa somam quase $73 \%$ do consumo e contam com 5,0\% e 10,8\% da população mundial, respectivamente, registrando alto consumo per capta. Desta forma, a disponibilização de biofármacos derivados de plasma para saúde em diferentes países reflete o "status" de desenvolvimento desses países.

Dentre as proteínas separadas de plasma e comercializadas, algumas têm maior demanda e determinam o volume de plasma necessário para fracionamento. A Figura 1 ilustra a distribuição do valor de mercado das proteínas hemoderivadas.

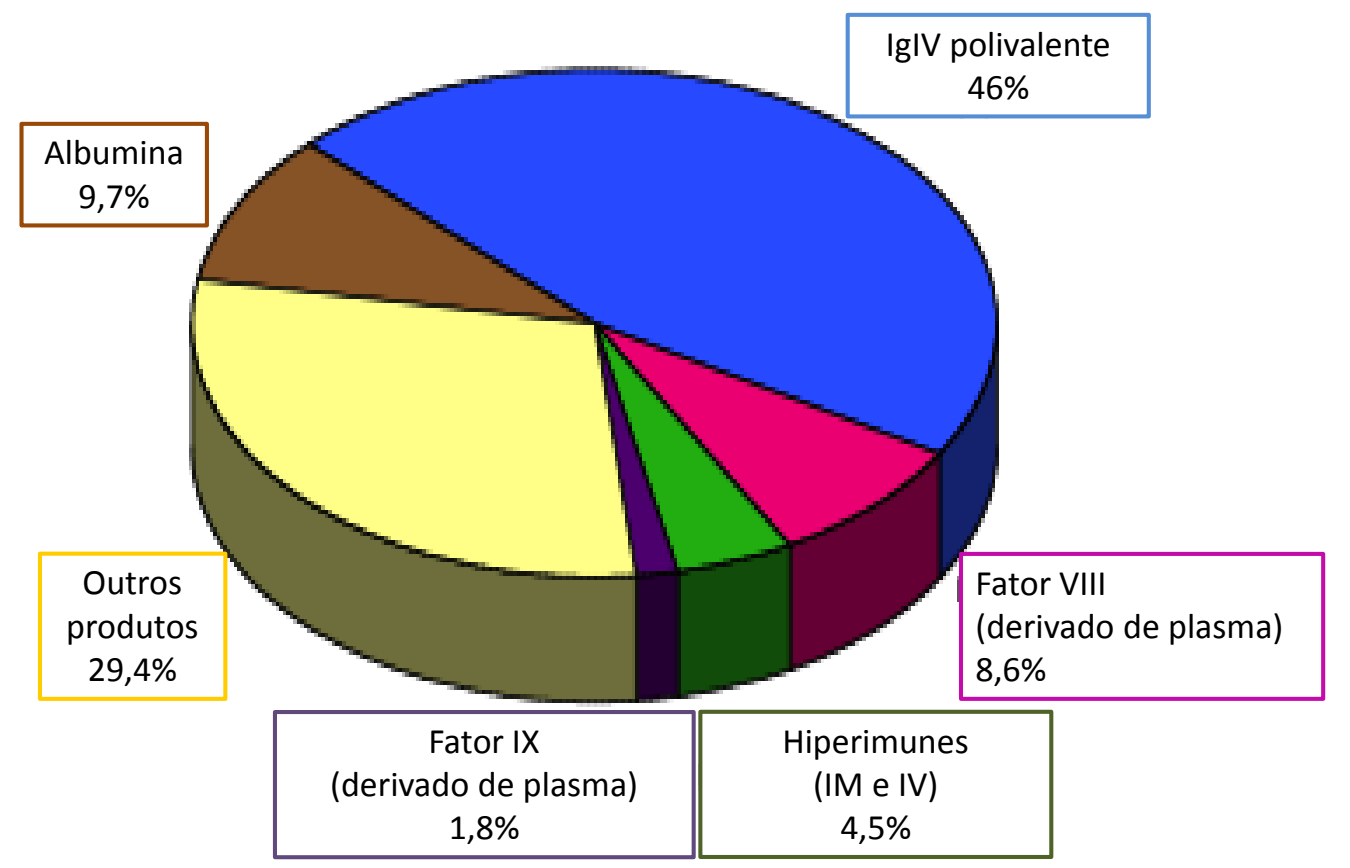

Figura 1 - Mercado de produtos de fracionamento de plasma em 2008 (sem produtos recombinantes). Valor total desse mercado foi de US\$11.778,8 milhões. Baseado em http://marketingresearchbureau.com/

Nos últimos 20 anos, preparações de IgIV têm mais alta demanda que qualquer outro dos produtos derivados de plasma e por isso esse produto determina o volume de plasma necessário em escala global. Pode-se dizer que Ig IV tem sido o motor do mercado de hemoderivados, em substituição a concentrados de fator VIII, o qual movia esse mercado até o inicio dos anos 90, quando o fator VIII recombinante começou a ser comercializado. Hoje IgIV representa 40-50\% do mercado de proteínas de plasma, variando significativamente entre as regiões do mundo (RADOSEVICH; BURNOUF, 2009). 
Por sua versátil aplicação e pela alta concentração no plasma, preparações de Igs tornaram-se os produtos mais importantes da indústria de fracionamento de plasma, enfatizando a necessidade de bons rendimentos no processo de purificação e condições de manufatura que permitam a eliminação robusta de contaminantes, incluindo vírus que possam proliferar no plasma, e as próprias proteínas do plasma, certas vezes indesejáveis no produto (RADOSEVICH; BURNOUF, 2009).

\subsection{Obtenção do plasma}

O plasma humano é obtido a partir de doações de sangue ou por plasma aférese, sistema em que, durante a doação, os componentes celulares do sangue são separados e retornam ao doador. Na doação de sangue total, os componentes celulares e o plasma são separados. Após os testes de qualidade as frações de hemácias e plaquetas tem utilização rápida devido a curta vida em armazenamento, 3 meses. A fração plasmática é congelada e pode ser utilizada em até dois anos, tanto em terapias como para o processamento industrial, para separação de proteínas e obtenção de biofármacos hemoderivados.

Os Estados Unidos da América foram pioneiros em coleta de plasma e fracionamento. Em 1978 eram coletados 5,6 milhões de litros de plasma e em 2010 o volume de coleta atingiu 18 milhões de litros, tanto por doações normais de sangue como por plasma aférese. Em 2010, cerca de 5,5 milhões de litros de plasma foram processados na Ásia e região do Pacifico e cerca de 17 milhões de litros foram processados na Europa (http://marketingresearchbureau.com/).

\subsection{0 processamento do plasma}

Para a purificação de proteínas de plasma em larga escala para fins comerciais, como os concentrados de imunoglobulina e albumina, as indústrias de fracionamento utilizam normalmente o processo de Cohn-Oncley (COHN et al., 1944; PILLEMER et al., 1941), com modificações que tornaram os produtos mais seguros e os processos mais econômicos. Modificações com passos opcionais de cromatografia foram introduzidos na manufatura para aprimorar a pureza e segurança contra vírus nos produtos ou ainda para isolar novos produtos plasmáticos (RADOSEVICH; BURNOUF, 2009). 
Novas metodologias de fracionamento têm sido propostas, como o fracionamento completo por cromatografias, dispensando as precipitações alcoólicas do método de Cohn.

\subsection{A indústria de fracionamento de plasma no Brasil}

A quantidade de bioprodutos derivados de plasma usada em um país é uma medida de desenvolvimento. A capacitação em realizar o fracionamento do plasma é uma medida de desenvolvimento tecnológico de um país (BARNA, 2001) por isso, o Instituto Butantan tem proposto a criação de uma fábrica.

No Brasil são coletados cerca de 800.000 litros de sangue por ano e separados cerca de 400.000 litros de plasma, sendo $25 \%$ armazenado como plasma fresco congelado, de onde as proteínas da coagulação podem ser fracionadas. Comparado a outros países esse volume é pequeno em relação ao número de habitantes.

Pequenas plantas de fracionamento de plasma foram montadas no Brasil, chegando a fracionar cerca de 45 mil litros de plasma por ano. No entanto, hoje o plasma de boa qualidade tem sido exportado para fracionamento pela empresa francesa LFB (Laboratoire Français du Fractionnement et des Biotechnologies) (SOARES, 2002).

Atualmente está em andamento no Brasil a construção de duas plantas de fracionamento de plasma, uma em Goiana, Pernambuco, de responsabilidade da Hemobrás (Empresa Brasileira de Hemoderivados), e outra, no Instituto Butantan, São Paulo - SP.

\subsubsection{Planta de fracionamento de plasma da HEMOBRÁS}

A planta de fracionamento de plasma da Hemobrás deverá fracionar 500 mil litros de plasma por ano, processando o plasma seguindo uma transferência de tecnologia da empresa LFB, cuja metodologia baseia-se no processo de Cohn (COHN et al., 1944) modificado, ou seja, fracionamento por precipitação das proteínas em presença de variadas concentrações de etanol e em diferentes temperaturas, processo semelhante ao da maioria das fábricas de hemoderivados no mundo. $O$ método de Cohn foi modificado por inclusão de etapas de cromatografias no processo de purificação (http://www.hemobras.gov.br/site/conteudo/index.asp). 


\subsubsection{Planta de fracionamento de plasma do Instituto Butantan}

A Planta de fracionamento de plasma do Instituto Butantan terá capacidade para fracionar 150 mil litros de plasma por ano. O processo de fracionamento é bastante diferente e baseia-se quase somente em cromatografias. $O$ esquema de purificação está apresentado na Figura 2. O processo foi baseado na literatura científica correlata e desenvolvido de forma integrada pelo grupo de pesquisa e desenvolvimento da GE-Healthcare.

A planta de fracionamento de plasma destina-se à produção de imunoglobulinas, albumina e dos fatores de coagulação FVIII e FIX.

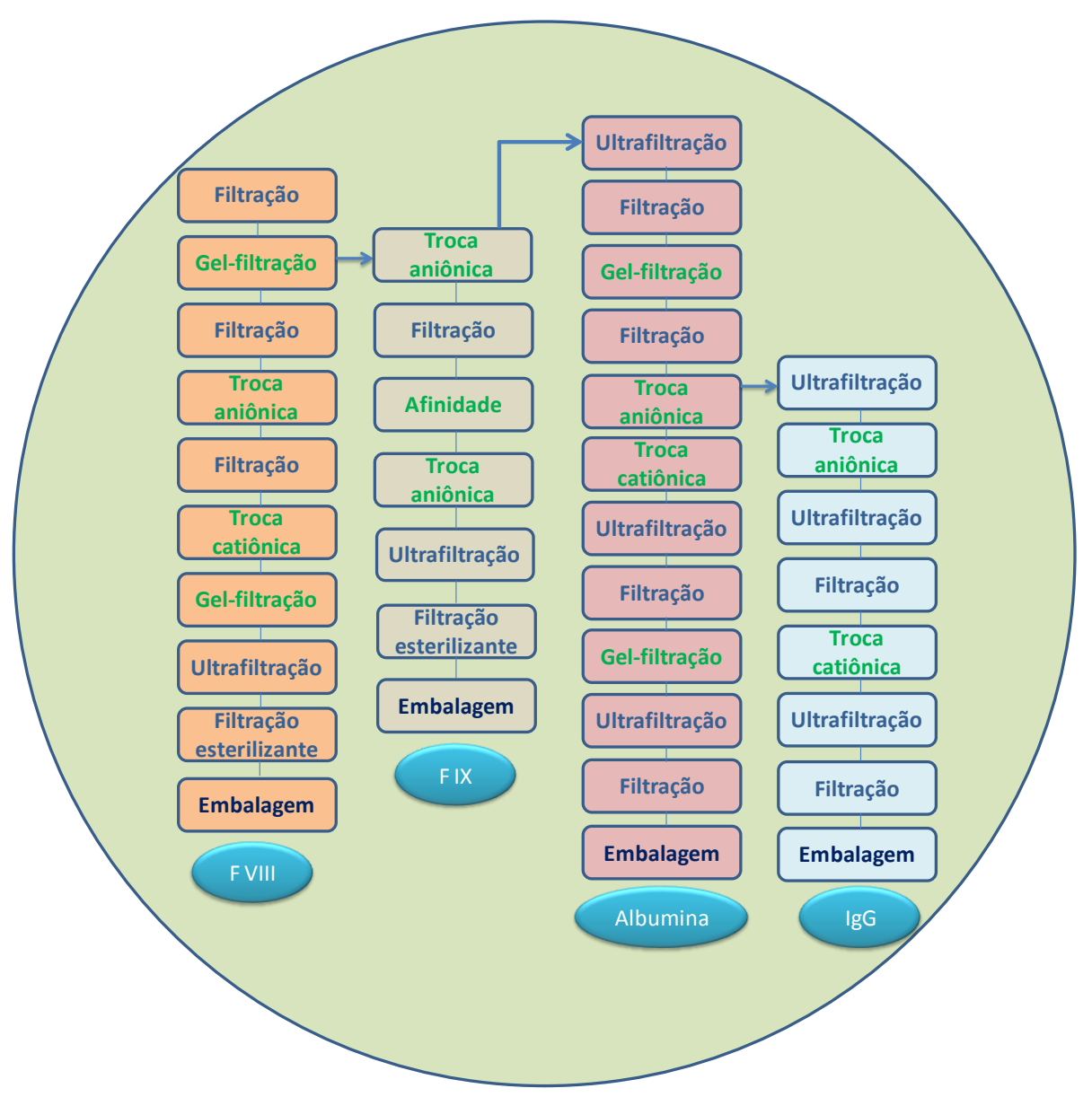

Figura 2 - Esquema geral do fracionamento de plasma na planta de hemoderivados do Instituto Butantan proposto em 2010. 


\subsubsection{A planta piloto no Instituto Butantan}

Paralelamente à construção da Planta Industrial de Hemoderivados, foi montada no Instituto Butantan uma Planta Piloto para a escala de 25 litros de plasma, reproduzindo a linha de fracionamento de Imunoglobulinas. Os primeiros processos ali realizados visavam o estabelecimento de parâmetros de filtração e centrifugação, além dos testes dos processos cromatográficos e testes de controle de qualidade dos produtos finais.

Outro processo estudado em nosso grupo de pesquisa é a aplicação direta do plasma em coluna de troca iônica para captura das proteínas dependentes de vitamina K e FVIII (CHENG et al., 2010) com o objetivo diminuir custos e tempo da primeira etapa do processo, uma cromatografia de gel filtração.

\subsection{Eventos adversos pós-infusão de IgIV - Associação com FXI contaminante}

As terapias que utilizam concentrados de imunoglobulinas são geralmente referidas como eficaz, com efeitos colaterais raros, suaves e passageiros. No entanto, eventos adversos sérios foram reportados incluindo: 1) anafilaxia devido a conteúdo residual de $\operatorname{lgA}$ em pacientes com deficiência de $\lg A$ e que possuem anticorpos anti-lgA; 2) Ativação de sistema complemento devido à presença de agregados de $\lg G$ ou outras proteínas de alto peso molecular; 3) Reações vasoativas devido a fatores do sistema de coagulação por contato, como ativador de pré-calicreína e calicreína, que mediam a geração de cininas; 4) Lesão pulmonar aguda presumivelmente relacionada à transfusão rápida de uma grande quantidade de anticorpos anti-granulócitos; 5) Eventos tromboembólicos (TEEs) devidos ao aumento de viscosidade do sangue. Esses eventos podem ocorrer devido à presença de proteínas plasmáticas consideradas contaminantes, influenciados pela condição do paciente, da doença que está sendo tratada ou do modo de administração, como a dose, fluxo de infusão e composição do produto (WU et al., 2014).

Os eventos TEEs ocorreram mais freqüentemente quando IgIV foi administrado em pacientes com níveis elevados de FXI. A correlação entre a concentração de FXI e eventos tromboembólicos já havia sido feita, uma vez que se evidenciou que 
pacientes com deficiência severa de $\mathrm{FXI}$ apresentam menor incidência de infarto isquêmico e trombose venosa (CROSBY et al., 2013).

Os TEEs foram relacionados à presença do $\mathrm{FXI}$ ou $\mathrm{FXI}$ ativado ( $\mathrm{FXla}$ ) (WU et al., 2014) nas preparações de $\mathrm{lg}$. Tais eventos podem resultar em enfarto do miocárdio, derrame cerebral, embolia pulmonar e trombose profunda nas veias.

De acordo com estudos de Etscheid et al. (ETSCHEID et al., 2012), calicreína e FXla são possíveis contaminantes em preparações de IgIV. Sendo que FXla é altamente pró-coagulante, sua presença nas preparações de IgIV foi correlacionada com a ocorrência TEEs.

Um relato recente demonstrou a presença de atividade pró-coagulante do FXI no biofármaco imunoglobulina humana normal, Octagam $\AA 5 \%$, da empresa Octapharma (Suíça), produto que está no mercado a mais de 17 anos, e com taxa de eventos adversos menor que $0,35 \%$ em 10 anos. No ano de 2010 um aumento em eventos tromboembólicos foi observado em pacientes após a administração de diferentes lotes de Octagam® $5 \%$. Todos os lotes do produto foram retirados de circulação e o produto suspenso até que as causas das complicações fossem esclarecidas e resolvidas por implementação de medidas de segurança. A presença de FXla foi confirmada por ensaios analíticos já estabelecidos, teste de "tempo parcial de tromboplastina não ativada" (NAPTT), e também por ensaios com configurações adaptadas, altamente específicos, utilizando diferentes substratos cromogênicos ou fluorescentes. O FXla foi confirmado como causa bioquímica nos TEEs associados com infusões de Octagam (ROEMISCH et al., 2012).

\subsection{A cascata de coagulação e o Fator XI}

A cascata de coagulação é didaticamente dividida em dois ramos, a via extrínseca, dependente de fator tissular, e a via intrínseca, que se inicia por ativação por contato (Figura 3).

O FXI circula no plasma complexado a cininogênio de alto peso molecular (HMWK) e junto com precalicreína e FXII são referidos como componentes da ativação da cascata de coagulação por contato (PONCZEK; GAILANI; DOOLITTLE, 2008).

O FXII é ativado in vitro por interações com superfícies carregadas negativamente, como Kaolin, ácido elágico, sulfato de dextrano ou sulfatídeos 
(SCOTT; SCHAPIRA; COLMAN, 1982a). O FXI é o zimogênio da protease de coagulação sanguínea, Fator Xla (FXla), que contribui para a hemóstase através da ativação de Fator IX, o que leva à via central da cascata de coagulação.

O FXIla ativa o FXI a FXla, porém o FXI também sofre auto-ativação e ativação por trombina em diferentes cinéticas (SCOTT et al., 1982b).

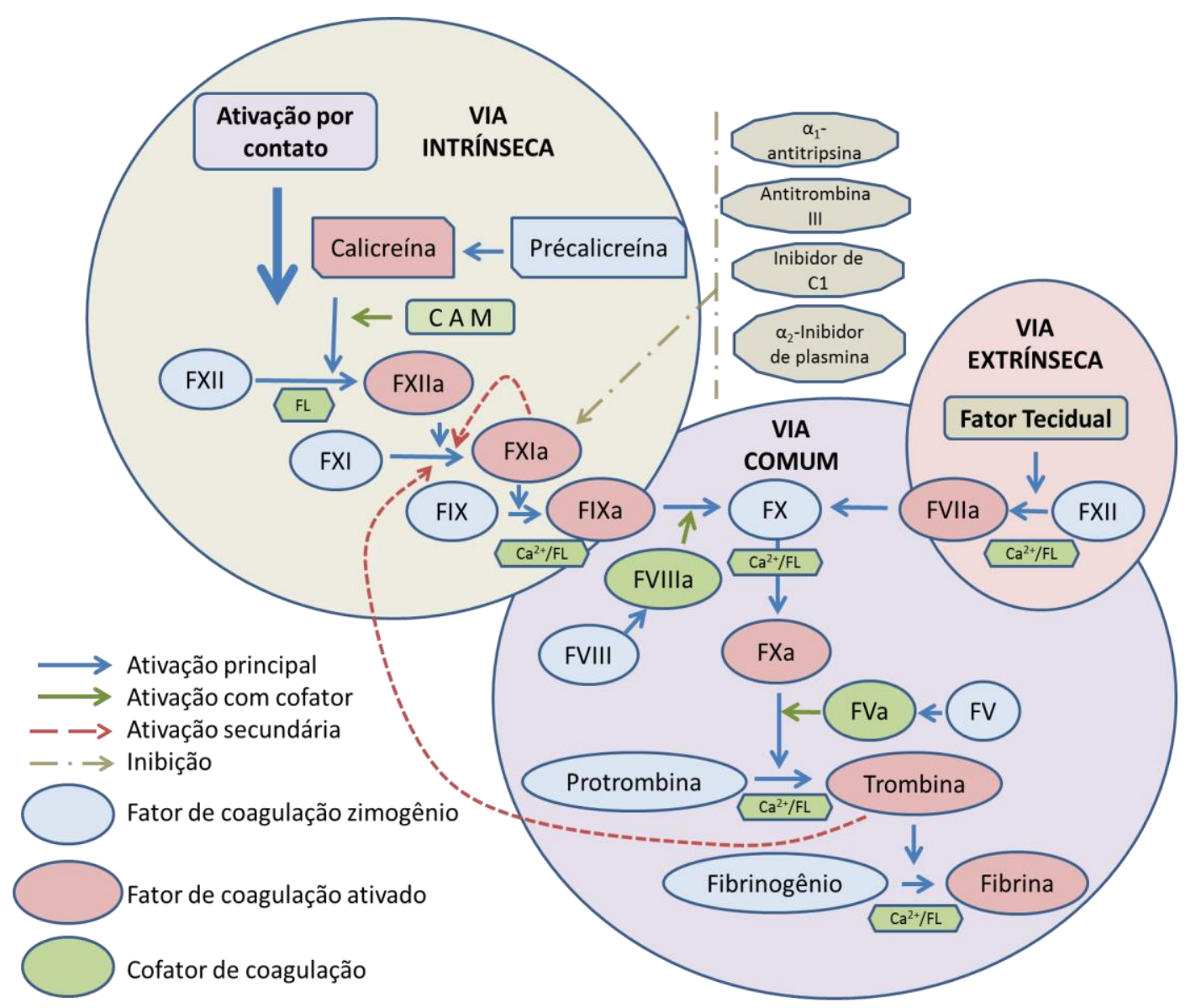

Figura 3 - Reações das proteases na cascata de coagulação do plasma. O esquema mostra o modelo de cascata de coagulação, iniciada pela ativação do FXII (ativação por contato) com a geração de trombina, onde: CAM - Cininogênio de alta massa molecular, $\mathrm{FL}$ - fosfolipídeos. $\mathrm{O}$ início da cascata de coagulação pelo complexo FVlla/fator tecidual até a ativação do FX também é ilustrado. Baseado em SCHALLER et al., 2008.

A proteína FXI é uma glicoproteína homodimérica de cadeias idênticas de 80 kDa com 607 aminoácidos, interligadas por pontes dissulfetos. Cada cadeia contem 4 repetições de 90 aminoácidos chamadas de domínios apple (A1 a A4 a partir do N- 
terminal) e um C-terminal com domínio catalítico trypsin like (Figura 4) (GAILANI; SMITH, 2009).

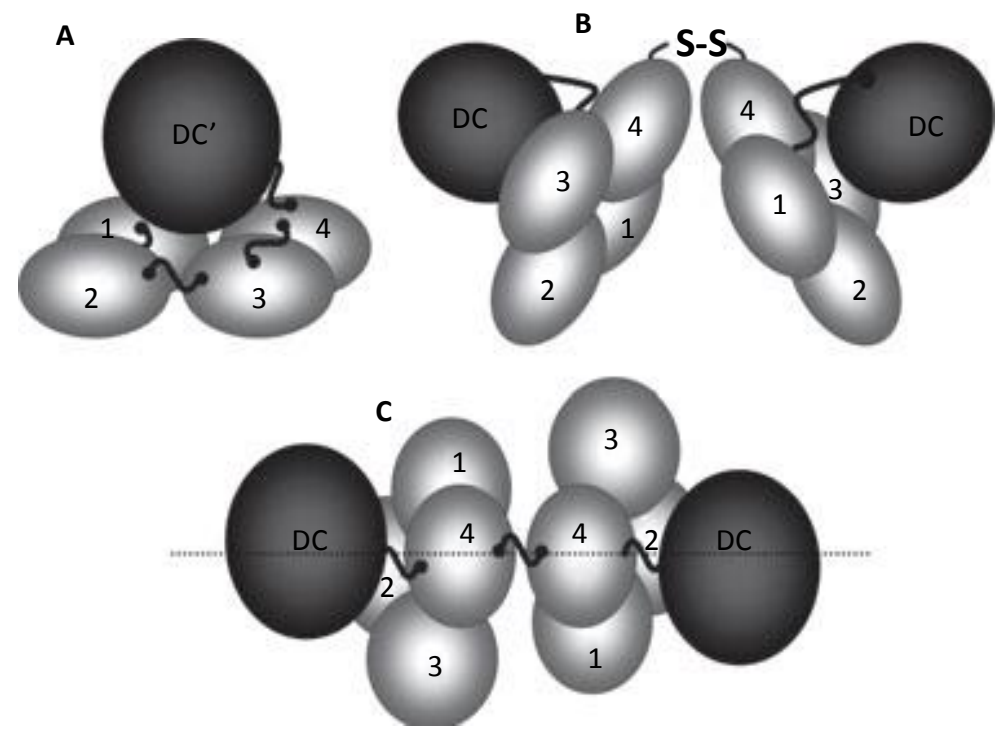

Figura 4 - Estrutura do FXI. A - Subunidade de FXI com 4 domínios Apple (1-4), que formam estrutura planar na qual o domínio catalítico (DC) se aloja. B - FXI, dímero de duas subunidades idênticas, com os domínios Apple formando a interface. C Dímeros do $\mathrm{FXI}$ em vista superior aos domínios A4, os dois domínios A3 podem ser vistos em lados opostos do plano longitudinal. FONTE: Gailani e Smith, 2009.

Novos estudos indicam o FXI como não responsável para a formação de fibrina, baseando-se no fato de que a deficiência de FXI causa sangramento relativamente suave. Admite-se que o FXla faz parte de um "loop" de "feedback" que sustenta a geração de trombina através da ativação de FIX para a consolidação da coagulação. Isto aparentemente é particularmente importante em tecidos com atividade fibrinolítica intensa, como da orofaringe e do trato urinário, que são locais de sangramento comuns em pacientes com deficiência de FXI (EMSLEY; MCEWAN; GAILANI, 2010). A deficiência congênita de FXI é associada com hemorragia de leve a moderada. Deficiência severa ( $<15 \%$ da atividade normal do plasma) é prevalente em população de descendência judaica (EMSLEY; MCEWAN; GAILANI, 2010).

Deficiências congênitas de proteínas dependentes de vitamina $K$ são normalmente associadas com disfunção dessas proteínas, enquanto a maioria dos casos de deficiência de FXI está associada com níveis baixos da proteína FXI no plasma.

Existe um novo interesse em FXI devido a estudos em populações e em modelos animais indicando que esta proteína contribui de maneira importante para trombose 
arterial, trombose venosa, lesão por isquemia e reperfusão no sistema nervoso central e na patologia da sepse. A observação de que a deficiência ou inibição de FXI interfere com o acúmulo de plaquetas no crescimento de trombos levou à reanálise do mecanismo envolvido na ativação do $F X I$ e suas interações com as plaquetas (EMSLEY; MCEWAN; GAILANI, 2010).

À complexa rede de zimogênios e proteases da cascata de coagulação, somamse as proteínas inibidoras do plasma. O FXla é inibido principalmente por alfa1antitripsina, e também por antitrombina III, inibidor de C1 e inibidor de alfa2plasmina (Figura 3).

No trabalho aqui apresentado procuramos rastrear a separação do $F X I$ em frações de plasma separadas pelos diferentes métodos citados, a cromatografia direta de plasma por troca iônica e cromatografia por gel filtração. Para tanto utilizamos diferentes métodos de dosagem de FXI considerando os muitos interferentes do sistema. 


\section{OBJETIVOS}

Neste trabalho propomos detectar a proteína FXI nas frações cromatográficas e no produto final obtidos no processo de purificação de Imunoglobulinas que será usado na planta de fracionamento de plasma do Instituto Butantan.

O FXI também será investigado em frações cromatográficas de um processo de purificação de hemoderivados proposto no laboratório por cromatografia direta de plasma em resina de troca aniônica.

\subsection{Objetivos específicos}

Estabelecer em escala de laboratório o processo de purificação de lgG que será usado na escala industrial;

Avaliar a presença de FXI nas frações cromatográficas por western blot e por atividade enzimática pró-coagulante;

Avaliar uma nova resina de pseudo afinidade ainda não comercializada para purificação de lgs e verificar a qualidade do produto separado em relação à presença de FXI. 


\section{MATERIAIS E MÉTODOS}

Dois processos de fracionamento de plasma humano são descritos.

O "Processo Cromatográfico" refere-se ao processo completo como desenhado para a planta industrial do Instituto Butantan. Descrevemos abaixo o processo em escala piloto e escala de bancada.

A "Cromatografia direta de plasma em Q-Sepharose" refere-se a um processo em desenvolvimento no laboratório.

\subsection{Processo cromatográfico do plasma em escala piloto}

Ao iniciarmos este trabalho, uma planta piloto para o processo cromatográfico de hemoderivados - linha de imunoglobulinas já estava montada. Descrevemos sucintamente as etapas do processo, volumes de coluna e soluções utilizadas nesse processo.

Os procedimentos de purificação foram realizados utilizando o equipamento Akta Pilot (GE-Helthcare), sendo o controle de cromatografias e coleta de dados feita usando o software Unicorn 5.1.

\subsubsection{Preparação do plasma humano}

Bolsas de plasma humano foram cedidas pela fundação Pró-Sangue, Hemocentro de São Paulo e pela Associação Beneficente de coleta de Sangue (Colsan) e foram mantidas em freezer $-80^{\circ} \mathrm{C}$.

Para o fracionamento, bolsas de plasma humano com volume aproximado de 200 $\mathrm{mL}$ foram descongeladas a $27^{\circ} \mathrm{C}$ em banho de água. Os plasmas foram misturados, independentemente dos tipos sanguíneos, para compor o volume necessário, 25 litros para processamento na escala piloto. Heparina (HEPAMAX-S, 5000 U.I./mL, Blaüsiegel) foi adicionada à mistura de plasmas para a concentração de 1000 unidades por litro. A mistura de plasma foi filtrada em algodão hidrofílico e em papel de filtro (Whatman). 
- Coluna: BPG 200/950 com volume de $20 \mathrm{~L}$ de resina Sepharose 4FF;

- Tampão de equilíbrio e eluição: Citrato de sódio $20 \mathrm{mM}$, cloreto de sódio 150 $\mathrm{mM}$, Cloreto de cálcio 2,6 mM, pH 7,0 e condutividade aproximada $17 \mathrm{mS} / \mathrm{cm}$;

- $25 \mathrm{~L}$ de plasma são processados na coluna de $20 \mathrm{~L}$ em 5 ciclos;

- Fluxo linear de $50 \mathrm{~cm} / \mathrm{h}$.

3.1.3 Etapa 2 - Cromatografia da fração F3-4FF por troca aniônica em resina DEAE Sepharose

- Coluna: BPG 140/500 com volume de 1,5 L de resina DEAE Sepharose FF;

- Tampão de equilíbrio 1: ácido cítrico 20 mM, pH 4,5;

- Tampão de equilíbrio 2: citrato de sódio $20 \mathrm{mM}, \mathrm{NaCl} 70 \mathrm{mM}, \mathrm{pH}$ 7,0, condutividade de aproximadamente $10 \mathrm{mS} / \mathrm{cm}$;

- Tampão de lavagem: citrato de sódio $20 \mathrm{mM}, \mathrm{NaCl} 150 \mathrm{mM}, \mathrm{pH}$ 7,0, condutividade de aproximadamente $16 \mathrm{mS} / \mathrm{cm}$;

- Tampão de eluição: citrato de sódio $20 \mathrm{mM}, \mathrm{NaCl} 340 \mathrm{mM}, \mathrm{pH} 7,0$ condutividade de aproximadamente $31 \mathrm{mS} / \mathrm{cm}$;

- 80 litros da fração de eluição da coluna anterior (gel filtração 4FF) são processados na coluna de 1,5 L, em 1 ciclo;

- Fluxo linear de $75 \mathrm{~cm} / \mathrm{h}$.

3.1.4 Etapa 3 - Dessalinização da fração F1-DEAE (flow through) da cromatografia em DEAE por cromatografia em resina sephadex-G25 e ajuste de $\mathrm{pH}$ para precipitação de euglobulinas

- F1-DEAE é concentrada por filtração tangencial em cartucho de fibra oca (GE Healthcare), de corte de $10 \mathrm{kDa}$;

- Coluna: BPG 200/950 com volume de 20 L de resina Sephadex G-25 Medium;

- Tampão de equilíbrio e eluição: Acetato de sódio cond. $5 \mu \mathrm{S} / \mathrm{cm}, \mathrm{pH} 7,0$;

- $25 \mathrm{~L}$ da fração F1-DEAE são processados na coluna Sephadex G25 de $20 \mathrm{~L}$ em 9 ciclos, recuperando-se aproximadamente $56 \mathrm{~L}$ correspondente ao Vo; 
- Fluxo linear $310 \mathrm{~cm} / \mathrm{h}$;

- Ajuste de pH da solução proteica para 5,2 e a amostra é mantida sob agitação branda a $4{ }^{\circ} \mathrm{C}$ por 15 horas para precipitação da euglobulina;

3.1.5 Etapa 4 - Separação do precipitado de euglobulinas por centrifugação contínua

- Centrífuga contínua Alfa Laval LAPX 404;

- O sobrenadante da suspensão de euglobulina é separado por centrifugação continua em vazão de $150 \mathrm{~L} / \mathrm{h}$;

3.1.6 Etapa 5 - Cromatografia do sobrenadante da precipitação de euglobulina em resina de troca aniônica (DEAE2) para separação de albumina

- Coluna BPG 140/500 com 2,5 L de resina DEAE Sepharose FF;

- Tampões de equilíbrio, acetato de sódio: cond. $150 \mu \mathrm{S} / \mathrm{cm}$, pH 4,5 e cond. 25 $\mu \mathrm{S} / \mathrm{cm}, \mathrm{pH} 5,2$;

- Tampões de eluição, acetato de sódio: cond. $20 \mu \mathrm{S} / \mathrm{cm}$, pH 5,2, cond. 25 $\mu \mathrm{S} / \mathrm{cm}, \mathrm{pH} 4,5$ e cond. $150 \mu \mathrm{S} / \mathrm{cm}, \mathrm{pH} 4,0$;

- $57 \mathrm{~L}$ de sobrenadante da centrifugação são processados na coluna de 2,5 L em 10 ciclos;

- Fluxo linear $307 \mathrm{~mL} / \mathrm{min}$.

3.1.7 Etapa 6 - Troca aniônica da fração F1-DEAE2 em Q Sepharose

- Coluna BPG 200/950 com 2,5 L de resina Q Sepharose FF;

- Tampão de equilíbrio: Acetato de sódio cond. $20 \mu \mathrm{S} / \mathrm{cm}, \mathrm{pH}$ 6,5;

- Tampão de eluição: Acetato de sódio cond. 0,5 mS/cm, pH 9,0;

- 27 litros de F1-DEAE2 (flow through) são processados na coluna $Q$ Sepharose em 10 ciclos;

- Fluxo linear de $120 \mathrm{~cm} / \mathrm{h}$. 
3.1.8 Etapa 7 - Inativação viral da fração $F 1-Q$ e Cromatografia de troca cationica em $C M$-Sepharose para eliminação dos agentes do tratamento de inativação

- Fibra oca (GE-Healthcare), corte de 30 kDa para concentração da F1-Q para 5\% de proteína;

- Adição de triton-X100 e tributirilfosfato (TNBP) e manutenção por 15 horas a 30 ${ }^{\circ} \mathrm{C}$ para desinfecção viral;

- Coluna BPG 100/500 com 0,8 L de resina CM-Sepharose FF;

- Tampão de equilíbrio: Acetato de sódio cond. $20 \mu \mathrm{S} / \mathrm{cm}, \mathrm{pH}$ 4,0;

- Tampão de lavagem: Glicina cond. $10 \mu \mathrm{S} / \mathrm{cm}, \mathrm{pH} 7,0$;

- Tampão de eluição: Glicina cond. $100 \mu \mathrm{S} / \mathrm{cm}$ + NaCl 150 mM, pH 9,0;

- 2,5 litros da fração F1-Q (flow through) são processados na coluna CMSepharose de 0,8 L em 2 ciclos;

- Fluxo linear de $120 \mathrm{~cm} / \mathrm{h}$;

- Fibra oca, corte de $30 \mathrm{kDa}$ para concentração da fração F3-CM por ultrafiltração/diafiltração de $8 \mathrm{~L}$ para $2 \mathrm{~L}$ com aproximadamente $5 \%$ de proteína e condutividade $500 \mu \mathrm{S} / \mathrm{cm}$;

- Formulação final de $\lg G 5 \%$ e sacarose como estabilizante (1 g por g de lgG);

- Esterilização por filtração em 0,22 $\mu \mathrm{m}$.

\subsection{Processo cromatográfico do plasma em escala de bancada}

\subsubsection{Preparação de plasma}

Para o fracionamento em escala de bancada, 5 bolsas de plasma humano com volume aproximado de $200 \mathrm{~mL}$ foram descongeladas a $27^{\circ} \mathrm{C}$ em banho de água. Os plasmas foram misturados, independentemente dos tipos sanguíneos, em becker de plástico. Heparina (HEPAMAX-S, 5000 U.I./mL, Blaüsiegel) foi adicionada à mistura para a concentração de 1000 unidades por litro. A mistura de plasma foi filtrada em algodão hidrofílico e em papel de filtro (Whatman). Enquanto na escala piloto processávamos $25 \mathrm{~L}$, na escala de bancada o processo é realizado com $420 \mathrm{~mL}$ de plasma. 
3.2.2 Montagem e manutenção das colunas de cromatografia

- Duas colunas XK 26/40 (GE Healthcare) foram montadas em série e interligadas, formando um único volume de coluna de $320 \mathrm{~mL}$ de resina: Sepharose 4FF (GE Healthcare), altura total de $60,4 \mathrm{~cm}$, diâmetro de $26 \mathrm{~mm}$. Empacotamento com 20 VC utilizando água Milli Rios, fluxo de $8 \mathrm{~mL} / \mathrm{min}$.

- Coluna C 16/20 (GE Healthcare) com resina DEAE Sepharose Fast Flow (GE Healthcare). Vinte e cinco $\mathrm{mL}$ de resina foram empacotados com altura de 12 $\mathrm{cm}$, diâmetro de $16 \mathrm{~mm}$ usando 20 VC de água Milli Rios em fluxo de 5 $\mathrm{mL} / \mathrm{min}$.

- As cromatografias foram processadas usando Cromatógrafo Äkta purifier (GE Healthcare) e os dados adquiridos com o programa Unicorn 5.2. As cromatografias foram acompanhadas por medida de absorbância em UV $280 \mathrm{~nm}$ e as frações foram indicadas nos cromatogramas.

3.2.3 Etapa 1- Separação de proteínas de plasma por gel filtração em resina Sepharose 4FF

\subsubsection{Soluções:}

- Tampão: Citrato de sódio $20 \mathrm{mM}$, cloreto de sódio $150 \mathrm{mM}$, Cloreto de cálcio 2,6 mM, pH 7,0 e condutividade de aproximadamente $17 \mathrm{mS} / \mathrm{cm}$;

\subsubsection{Procedimento}

A coluna foi equilibrada com 3 volumes de coluna do tampão citrato. O fluxo linear utilizado foi de $50 \mathrm{~cm} / \mathrm{h}$, fluxo volumétrico de $4,43 \mathrm{~mL} / \mathrm{min}$. $70 \mathrm{~mL}$ (22\% de volume de coluna) do plasma previamente misturado (item 3.2.1) foi carregado na coluna Sepharose 4FF por 6 ciclos consecutivos com $70 \mathrm{~mL}$ de plasma por ciclo. Após o carregamento de amostra, o mesmo tampão foi utilizado como fase móvel. Quatro frações foram coletadas. 


\subsubsection{Soluções}

- Tampão de equilíbrio 1 - ácido cítrico 20 mM, ph 4,5;

- Tampão de equilíbrio 2 - citrato de sódio $20 \mathrm{mM}, \mathrm{NaCl} 70 \mathrm{mM}, \mathrm{pH}$ 7,0, condutividade de aproximadamente $10 \mathrm{mS} / \mathrm{cm}$;

- Tampão de lavagem - citrato de sódio $20 \mathrm{mM}, \mathrm{NaCl} 150 \mathrm{mM}, \mathrm{pH} \mathrm{7,0}$, condutividade de aproximadamente $16 \mathrm{mS} / \mathrm{cm}$;

- Tampão de eluição - citrato de sódio $20 \mathrm{mM}, \mathrm{NaCl} 340 \mathrm{mM}, \mathrm{pH} 7,0$ condutividade de aproximadamente $31 \mathrm{mS} / \mathrm{cm}$;

\subsubsection{Procedimento}

O processo em resina DEAE Sepharose foi realizado em fluxo linear de $75 \mathrm{~cm} / \mathrm{h}$ e fluxo volumétrico de $2,5 \mathrm{~mL} / \mathrm{min}$.

A coluna foi equilibrada com 1,5 volume de coluna do tampão de equilíbrio 1 e 7 volumes de coluna do tampão de equilíbrio 2.

Aproximadamente $1 \mathrm{~L}$ da fração $\mathrm{F} 3$ coletada na primeira etapa do processo foi carregada na coluna, recolhendo-se o "flow through" como fração F1. Após o carregamento da amostra a coluna foi lavada com 2 VC de tampão de equilíbrio $2 \mathrm{e}$ com 7 VC de tampão de lavagem para eluição de contaminantes não ligados à coluna.

As proteínas dependentes de vitamina $\mathrm{K}$ adsorvidas a coluna são eluídas e a fração F4-DEAE coletada consiste em um concentrado de proteína, determinado pela absorbância maior ou igual a $50 \mathrm{mAU}$.

\subsection{Cromatografia direta de plasma em coluna Q Sepharose}

Um método baseado em "Cromatografia Direta de Plasma em coluna de troca iônica Q Sepharose" está em desenvolvimento no laboratório de Biotecnologia Molecular III no Instituto Butantan. Frações cromatográficas de plasma separadas por esse método foram usadas para verificar a separação do FXI. 
- Coluna pré-empacotada de troca aniônica Q FF HiTrap (GE Healthcare) de 5 $\mathrm{mL}$;

- Cromatógrafo Äkta purifier (GE Healthcare) com programa Unicorn 5.2;

\subsubsection{Preparo do plasma}

- Bolsas de plasma foram descongeladas em banho de $27^{\circ} \mathrm{C}$ e o plasma filtrado em algodão e filtro de papel (Whatman);

- O pH do plasma foi ajustado para 6,0 com ácido cítrico 25 mM;

Observação - Quando indicado, o pH do plasma não foi ajustado, sendo aplicado à cromatografia no $\mathrm{pH}$ original, $~ 7,4$.

\subsubsection{Soluções}

- Tampão de equilíbrio e lavagem: Citrato de sódio $25 \mathrm{~mm}, \mathrm{CaCl}_{2} 5 \mathrm{mM}, \mathrm{NaCl}$ $150 \mathrm{mM} ; \mathrm{pH}$ 6,0;

- Tampão de eluição: Citrato de sódio $25 \mathrm{mM}, \mathrm{CaCl}_{2} 5 \mathrm{mM}, \mathrm{NaCl} 500 \mathrm{mM} ; \mathrm{pH}$ 6,0 .

Observação - Quando o experimento foi realizado com plasma no $\mathrm{pH} \sim 7,4$, foram usados os mesmos tampões, porém em pH 6,4.

\subsubsection{Procedimento}

- A coluna foi equilibrada com 15 VC de tampão de equilíbrio, com fluxo volumétrico de $5 \mathrm{~mL} / \mathrm{min}$;

- $25 \mathrm{~mL}$ de plasma foram carregados na coluna Q-Sepharose, recolhendo-se o "flow through" como fração FT;

- Após o carregamento da amostra, a coluna foi lavada com 5 VC de tampão de equilíbrio para remover proteínas não ligadas à coluna;

- Após a lavagem, foi aplicado 5 VC do tampão de eluição. Os volumes recolhidos como fração de eluição (EL) são indicados nos experimentos; 


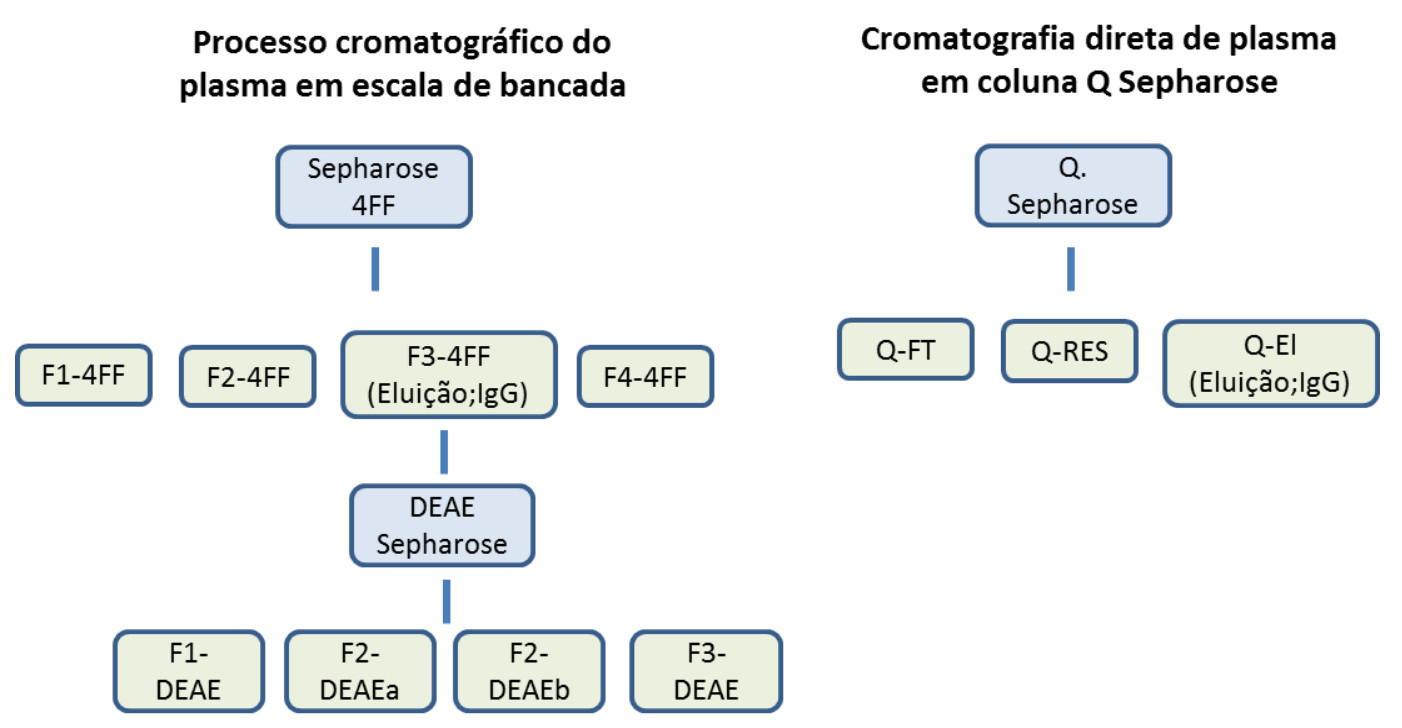

Figura 5 - Fluxograma dos processos cromatográficos do plasma em escala de bancada e cromatografia direta de plasma em coluna Q Sepharose.

\subsection{Métodos analíticos}

3.4.1 Eletroforese em gel de poliacrilamida - SDS-PAGE

3.4.1.1 Materiais e soluções utilizadas

- Marcador molecular (Pierce);

- Acrilamida 30\%: Acrilamida 29\% (Amersham), bis-acrilamida 1\% (Amersham) em $\mathrm{H}_{2} \mathrm{O}$ Milli Q;

- Tampão Tris-HCl: Tampão Tris-HCl (Cal biochem) 1,5 M, SDS (Gibco BRL) $0,1 \%, \mathrm{pH} 8,8$;

- Tampão Tris-HCl pH 6,8: Tampão Tris-HCl 0,5 M, SDS 0,1\%, pH 6,8;

- TEMED (N,N,N',N' Tetrametiletilenodiamina) (Sigma);

- Solução de persulfato de amônio: persulfato de amônio (BRL) 10\%;

- Tampão de corrida: tampão Tris- $\mathrm{HCl}$ (Cal biochem) 0,025 M, glicina (Nuclear) 0,192 M, SDS (Gibco BRL) 0,1\%, pH 8,3;

- Tampão de amostra: Tris-HCl $50 \mathrm{mM} \mathrm{pH} \mathrm{6,8,} \mathrm{SDS} \mathrm{10 \% ,} \mathrm{azul} \mathrm{de} \mathrm{bromofenol}$ 0,1\%, glicerol 10\%, $\beta$-mercaptoetanol $100 \mathrm{mM}$, água MilliQ;

- Cuba para eletroforese Biorad; 
- Fonte para eletroforese: Eletrophoresis Power Supply EP5600 (Pharmacia Biotec).

\subsubsection{Procedimento}

Amostras das purificações foram analisadas por SDS-PAGE. Os géis de poliacrilamida foram preparados segundo metodologia descrita por Laemmli (1970). O gel de separação foi preparado (para um volume de $10 \mathrm{~mL}$ ) com $10 \%$ de poliacrilamida em tampão Tris- $\mathrm{HCl}$ 1,5 M, pH 8,8 e SDS 0,1\%. Foram adicionados 10 $\mu \mathrm{L}$ de TEMED e $100 \mu \mathrm{L}$ de persulfato de amônio para polimerização. $\mathrm{O}$ gel de empacotamento foi preparado (para um volume de $5 \mathrm{~mL}$ ) na concentração $5 \%$ de poliacrilamida em tampão Tris- $\mathrm{HCl} 0,5 \mathrm{M} \mathrm{pH} \mathrm{6,8,} \mathrm{SDS} \mathrm{0,1 \% .} \mathrm{Foram} \mathrm{adicionados} 5$ $\mu \mathrm{L}$ de TEMED e $50 \mu \mathrm{L}$ de persulfato de amônio para polimerização.

As amostras foram preparadas adicionando $5 \mu \mathrm{L}$ de tampão de amostra a $15 \mu \mathrm{L}$ de amostra de purificação e aquecidos à $98{ }^{\circ} \mathrm{C}$ por 5 minutos, $10 \mu \mathrm{L}$ dessa mistura foram aplicados ao gel. As corridas foram realizadas em tampão de corrida (Trisglicina), Aplicando corrente elétrica de $120 \mathrm{~V}$ por aproximadamente 120 minutos.

\subsubsection{Coloração do gel com solução de Coomassie blue}

- Corante Coomassie Blue G-250 - Coomassie Blue G-250 0,12\%, ácido fosfórico $10 \%$, sulfato de amônio $10 \%$, metanol $20 \%$, água MilliQ;

- Descorante - $\mathrm{H}_{2} \mathrm{O}$ Milli Rios;

Os géis foram corados com corante Coomassie Blue G-250 por aproximadamente 16 horas, lavados e descorados com água Milli Rios por 4 horas, com troca de água a cada 30 minutos.

\subsubsection{Western Blot}

A presença de FXI nas frações cromatográficas foi avaliada por western blot. 
3.4.2.1 Materiais e soluções utilizadas

- Membranas de PVDF (Difluoreto de polivinilideno) (Immobilon P, Millipore);

- Solução basal: $\mathrm{NaCl} 150 \mathrm{mM}$, Tris Base $10 \mathrm{mM} \mathrm{pH}$ 7,4 e tween 0,05\%;

- Tampão de transferência: Tris Base 25 mM pH 8,0, glicina 192 mM, SDS $0,02 \%$ e metanol $20 \%$;

- Corante de Ponceau: Ponceau S 0,5\%, ácido acético glacial 10\% e água milli Q;

- Solução de bloqueio: leite desnatado 10\%, BSA 1\% em solução basal;

- Kit de revelação: SuperSignal, West Pico Chemiluminescent Substrate (Thermo Scientific);

- Aparelho foto-documentador: Gel Logic 2200 (Imagine System);

- Programa: Care stream;

- Primeiro anticorpo: IgG anti-FXI (FXI G2, mouse monoclonal lgG1 Santa Cruz);

- Segundo anticorpo: Rabbit anti-mouse (IgG HRP, Santa Cruz);

- Fator XI humano purificado (HTI);

- Fator Xla humano purificado (HTI).

\subsubsection{Procedimento}

Para avaliar a presença de anticorpos específicos nas frações, as proteínas foram separadas por SDS-PAGE e transferidas para membranas de PVDF. A transferência foi realizada pela passagem de corrente elétrica de $300 \mathrm{~mA}$ por aproximadamente 3,5 horas em gelo. O tempo de transferência está diretamente relacionado com o tamanho da proteína, quanto menor a massa molecular mais fácil a proteína é transferida. Para avaliar a qualidade da transferência, as membranas foram coradas com solução de Ponceau $S$ para a visualização das bandas de proteína. As membranas foram lavadas com água e bloqueadas com solução TBS com $10 \%$ de leite em pó desnatado, sendo incubadas por aproximadamente 3 horas com agitação em TA.

Após o bloqueio, as membranas foram incubadas com a mesma solução contendo o primeiro anticorpo, IgG anti-FXI. A diluição do anticorpo, em geral, foi de 1:250 e 1:500. As membranas foram incubadas com a solução de anticorpos por 16 
horas a $4 \stackrel{\circ}{\mathrm{C}} \mathrm{com}$ agitação. As membranas foram lavadas 4 vezes por 10 minutos cada com solução de TBS (solução basal - $\mathrm{NaCl} 150$ mM, Tris Base 10 mM pH 7,4 e tween $0,05 \%$ ). O segundo anticorpo foi adicionado na solução de bloqueio na diluição apropriada sugerida pelo fabricante e as membranas foram incubadas por 2 horas a TA sob agitação.

As membranas foram lavadas 4 vezes por 10 minutos cada, incubadas com a solução de revelação por 5 minutos e expostas até o aparecimento das bandas (10 a 30 minutos).

\subsubsection{Remoção de albumina de frações cromatográficas em resina Star Hypercell}

A resina Hypercell STAR AX (PALL) de troca aniônica é desenhada para captura de albumina em alta concentração de sal (condutividade $6 \mathrm{mS} / \mathrm{cm}$ ). Essa resina foi usada para diminuir a concentração de albumina em amostras de plasma e frações cromatográficas, com o objetivo de diminuir a interferência dessa proteína nos géis e ensaios de western blot para detecção de FXI.

\subsubsection{Preparo da coluna com resina Star Hypercell}

Cinco $\mathrm{mL}$ de resina Star Hypercell foram empacotados em uma coluna XK $10 / 12(\varnothing 1,0 \mathrm{~cm})$ com $6,5 \mathrm{~cm}$ de altura com água purificada em fluxo de $10 \mathrm{~mL} / \mathrm{min}$. A sanitização dessa coluna foi feita com $\mathrm{NaOH} 1 \mathrm{M} \mathrm{em}$ tempo de contato de 1 hora. A coluna foi lavada com água purificada e armazenada com solução $\mathrm{NaOH} 10 \mathrm{mM}$

\subsubsection{Preparo do plasma}

- O plasma com $1 \mathrm{U} / \mathrm{mL}$ de heparina (Hepamax) teve o $\mathrm{pH}$ ajustado para 7,3 com solução de $\mathrm{NaH}_{2} \mathrm{PO}_{4} 1 \mathrm{M}$ e foi diluído lentamente com aproximadamente 1,5 volume de água purificada, até baixar a condutividade para $6 \mathrm{mS} / \mathrm{cm}$ (concentração final 40\%). O plasma diluído foi filtrado em algodão e filtro de papel (Whatman) e alíquotas de $45 \mathrm{~mL}$ foram congeladas. 


\subsubsection{Tampões e fluxos utilizados}

- A coluna foi equilibrada com tampão de equilíbrio - $20 \mathrm{VC}$ de fosfato de sódio $20 \mathrm{mM}, 80 \mathrm{mM} \mathrm{NaCl}, \mathrm{pH}$ 7,4, condutividade $11 \mathrm{mS} / \mathrm{cm}$, em fluxo de $5 \mathrm{~mL} / \mathrm{min}$;

- $50 \mathrm{~mL}$ de plasma diluído foram aplicados em fluxo de 2,5 mL/min. Frações de flow through foram coletadas para analise da capacidade de captura de albumina;

- A coluna foi lavada com $5 \mathrm{CV}$ do mesmo tampão de equilíbrio em fluxo de 5 $\mathrm{mL} / \mathrm{min}$;

- A albumina ligada foi eluída com aproximadamente 10 VC de Tampão de eluição - acetato de sódio $20 \mathrm{mM}, \mathrm{NaCl} 80 \mathrm{mM}, \mathrm{pH}: 4.0$, em fluxo de 5 $\mathrm{mL} / \mathrm{min}$.

Obs. Uma "Nova resina" de pseudo afinidade por IgG, ainda não comercializada, foi testada em caráter preliminar para investigar a presença de FXI em frações cromatográficas por western blot. Alguns resultados são apresentados como amostras que sofreram cromatografia nessa "Nova Resina", embora os procedimentos ainda não sejam descritos.

3.4.4 Dosagem de atividade FXI medindo cinética de formação do coágulo em leitor de ELISA

\subsubsection{Materiais e soluções}

- Placas de ELISA;

- Plasma humano deficiente em FXI (Cryocheck, Precision Biologic);

- Actin, cefalina ativada, cefalina em 0,1 mM de ácido elágico, (Activated Cephaloplastin Reagent, Dade, Siemens);

- Tampão - Tris-HCl 20 mM, NaCl 150 mM, pH 7,4;

- Solução de Cloreto de cálcio 30 mM;

- Amostras de plasma e de frações de cromatografias.

- Aparelho: SPECTRA Max 340PC (Molecular Devices); Esse equipamento permite incubações a $37^{\circ} \mathrm{C}$ e agitação automática da placa. 
- A cinética de reação de formação do coagulo é acompanhada por leitura de absorbância a $405 \mathrm{Nm}$ e os dados coletados utilizando software SoftMax Pro 6.1 ;

\subsubsection{Procedimento}

- Diferentes colunas das placas de ELISA receberam os reagentes, plasma deficiente em FXI, Actin, amostras e solução de cálcio, para possibilitar pipetagem simultânea usando pipeta multicanal;

- Foram adicionados $40 \mu \mathrm{L}$ de Actin aos poços com $40 \mu \mathrm{L}$ de plasma deficiente em FXl;

- Foram adicionados $10 \mu \mathrm{L}$ das amostras;

- A placa foi incubada a $37^{\circ} \mathrm{C}$ por 3 minutos e agitada por 1 segundo a cada 20 segundos;

- Foram adicionados $40 \mu \mathrm{L}$ de solução de $\mathrm{CaCl}_{2}$;

- As leituras foram feitas em $405 \mathrm{~nm}$, com agitação inicial por 5 segundos, e leituras a cada 4 segundos por tempo total de 3 minutos (37 leituras), com agitação de 1 segundo entre cada leitura.

\subsubsection{Cálculos de atividade de FXI por curva padrão com diluições de plasma}

- A cada ensaio, amostras de diferentes diluições do plasma do experimento são usadas para estabelecer uma curva padrão de atividade de FXI;

- Os tempos de coagulação são considerados os tempos na inflexão das curvas cinéticas de coagulação (o valor é dado pelo programa SoftMaxpro, considerando absorbância inicial igual a zero);

- Uma curva de correlação é gerada com os logaritmos dos valores de tempo de formação do coágulo (em segundos) em função dos logaritmos da concentração de plasma;

- Uma equação Logt $=a^{*} \log [$ plasma] + b é estabelecida e os tempos de coagulação das amostras são aplicados à equação e é calculada a atividade de FXI na amostra como concentração relativa de plasma. Além do cálculo de atividade de FXI na amostra, também é calculada a atividade de FXI na 
fração cromatográfica, multiplicando-se a atividade dosada pelo volume da fração.

3.4.5 Dosagem de atividade de FXI por método amidolítico, com substrato cromogênico S-2366

O ensaio amidolítico para dosagem de $\mathrm{FXI}$ foi realizado com algumas modificações feitas no protocolo descrito por Scott et al. (1984).

A dosagem de FXla sofre diversas interferências, uma vez que o fator é inibido por fatores plasmáticos, reguladores da coagulação, sendo o inibidor mais efetivo $\alpha_{1}$-antitripsina, responsável por $68 \%$ da atividade inibitória no plasma (SCOTT et al., 1984). A antitrombina-III, na presença ou ausência de heparina, é responsável por $16 \%$ da inibição do fator Xla e inibidor de $\mathrm{C} 1$ e inibidor de $\alpha_{2^{-}}$ plasmina são responsáveis pelo restante da atividade inibitória.

Além dos inibidores de $\mathrm{FXI}$, a dosagem desse fator sofre interferências de FXII e de calicreina (SCOTT et al., 1984). O FXIla e calicreína sofrem ação de inibidores de tripsina oriundos de plantas, sendo inibidores relativamente específicos o inibidor de tripsina de milho e de soja respectivamente. Esses inibidores não inibem o FXla, substancialmente. Portanto, na dosagem de FXI utilizam-se várias estratégias para bloquear a ação dos inibidores e interferentes.

O substrato S-2366, PyrGlu-Pro-Arg-pNA (chromogenix), embora não específico para FXla, pode ser utilizado no ensaio desde que seja feita a inativação de inibidores de FXla e a inibição de outras enzimas que hidrolisam o mesmo substrato. $O$ tratamento de plasma com clorofórmio para inativação de $\alpha_{1}$ antitripsina, inibidor de $\mathrm{C} 1$ e de outros inibidores de protease são descritos nos próximos tópicos

\subsubsection{Materiais e soluções}

- Placas de ELISA;

- Substrato amidolitico S-2366 (PyrGlu-Pro-Arg-pNA, Chromogenix), liofilizado (6 $\mathrm{mg}$ ). Ressuspendido em 7,2 mL de água purificada (1,54 mM) e alíquotas de 
$1 \mathrm{~mL}$ armazenadas a $-20^{\circ} \mathrm{C}$. No momento de uso, a solução de substrato foi diluída $1: 2$ em água purificada $(0,77 \mathrm{mM})$;

- Salina ( $\mathrm{NaCL}$ 0,9\%);

- Inibidor de tripsina de soja (STI), (Sigma);

- inibidor de tripsina de milho (CTI), $1 \mathrm{mg} / \mathrm{mL}$, diluído em salina para $0,5 \mathrm{mg} / \mathrm{mL}$ (Haematologic Technologies)

- Plasma humano deficiente em FXI (Cryocheck, Precision Biologic);

- Actin, cefalina ativada (Activated Cephaloplastin Reagent, Dade, Siemens);

- Amostras de plasma e de frações de cromatografias.

- Aparelho: SPECTRA Max 340PC (Molecular Devices);

- A cinética de reação de hidrólise de substrato é acompanhada por leitura de absorbância a $405 \mathrm{Nm}$ e os dados coletados utilizando software SoftMax Pro 6.1 ;

\subsubsection{Procedimento}

- $60 \mu \mathrm{L}$ de plasma pobre em $\mathrm{FXI}+15 \mu \mathrm{L}$ amostras em teste em tubo eppendorf de $1,5 \mathrm{~mL}$ receberam $75 \mu \mathrm{L}$ de $\mathrm{CHCl}_{3}$ para inativação de inibores. A mistura foi agitada por inversão durante 1 minuto em temperatura ambiente e então foi centrifugada a $12000 \mathrm{~g}$ por 5 minutos;

- $50 \mu \mathrm{L}$ do plasma tratado (fase superior) foram transferidos para um poço da placa de ELISA contendo $5 \mu \mathrm{L}$ de STI $50 \mu \mathrm{M}$, para inativação de calicreína;

- O FXII foi ativado por adição de $5 \mu \mathrm{L}$ de cefalina/ácido elágico. A amostra foi agitada no leitor de placas por 5 segundos e incubada a $37^{\circ} \mathrm{C}$ por 20 minutos;

- Com auxílio de pipeta multicanal $30 \mu \mathrm{L}$ da mistura de plasma foram transferidos para outra fileira de poços da placa contendo $7,5 \mu \mathrm{L}$ de CTI para inativação do FXIla, impedindo sua ação sobre o substrato;

- Utilizando pipeta multicanal, $10 \mu \mathrm{L}$ da amostra ativada foram adicionados a outro poço da placa de ELISA contendo $120 \mu \mathrm{L}$ do substrato S-2366 diluído aquecido a $37^{\circ} \mathrm{C}$, sendo iniciada a reação amidolítica. As leituras foram feitas em $490 \mathrm{Nm}$ e $405 \mathrm{Nm}$ a cada 5 minutos por 30 minutos. 


\subsubsection{Cálculo da atividade de FXI}

Diferentes diluições de plasma do experimento do dia são usadas para estabelecer uma curva padrão de FXI. A cinética da reação é acompanhada por variação da absorbância com o tempo.

Os coeficientes angulares das curvas cinéticas $(\Delta \mathrm{Abs} / \Delta \mathrm{T})$ são plotados em função da concentração de plasma, estabelecendo-se uma equação linear

$\Delta \mathrm{Abs} / \Delta \mathrm{T}=\mathrm{a}[$ plasma $]+\mathrm{b}$

- O coeficiente angular da curva cinética de cada amostra é inserido na equação para o cálculo da atividade de FXI (atividade relativa a concentração de plasma) na amostra. No computo de atividade de FXI em frações cromatográficas, além do cálculo de atividade do fator na amostra, a atividade de FXI total na fração é calculada multiplicando-se pelo valor da diluição da fração em relação ao volume aplicado na cromatografia. 


\section{RESULTADOS}

\subsection{Purificação de IgG em escala piloto}

O processo cromatográfico desenhado para a planta industrial de fracionamento de plasma foi reproduzido em escala para verificar se o produto Imunoglobulinas (aqui considerado como $\lg G$ ) era isento de FXI. Acompanhado o perfil cromatográfico em cada etapa e o perfil proteico das frações por SDS-PAGE. Os experimentos em escala piloto foi uma colaboração entre a equipe do hemoderivados do Instituto Butantan e a equipe de desenvolvimento de processos da GE-Healthcare. O processo de produção de $\lg G$ em escala piloto (25 $\mathrm{L}$ de plasma) foi realizado de maneira completa ou parcial (Figura 6).

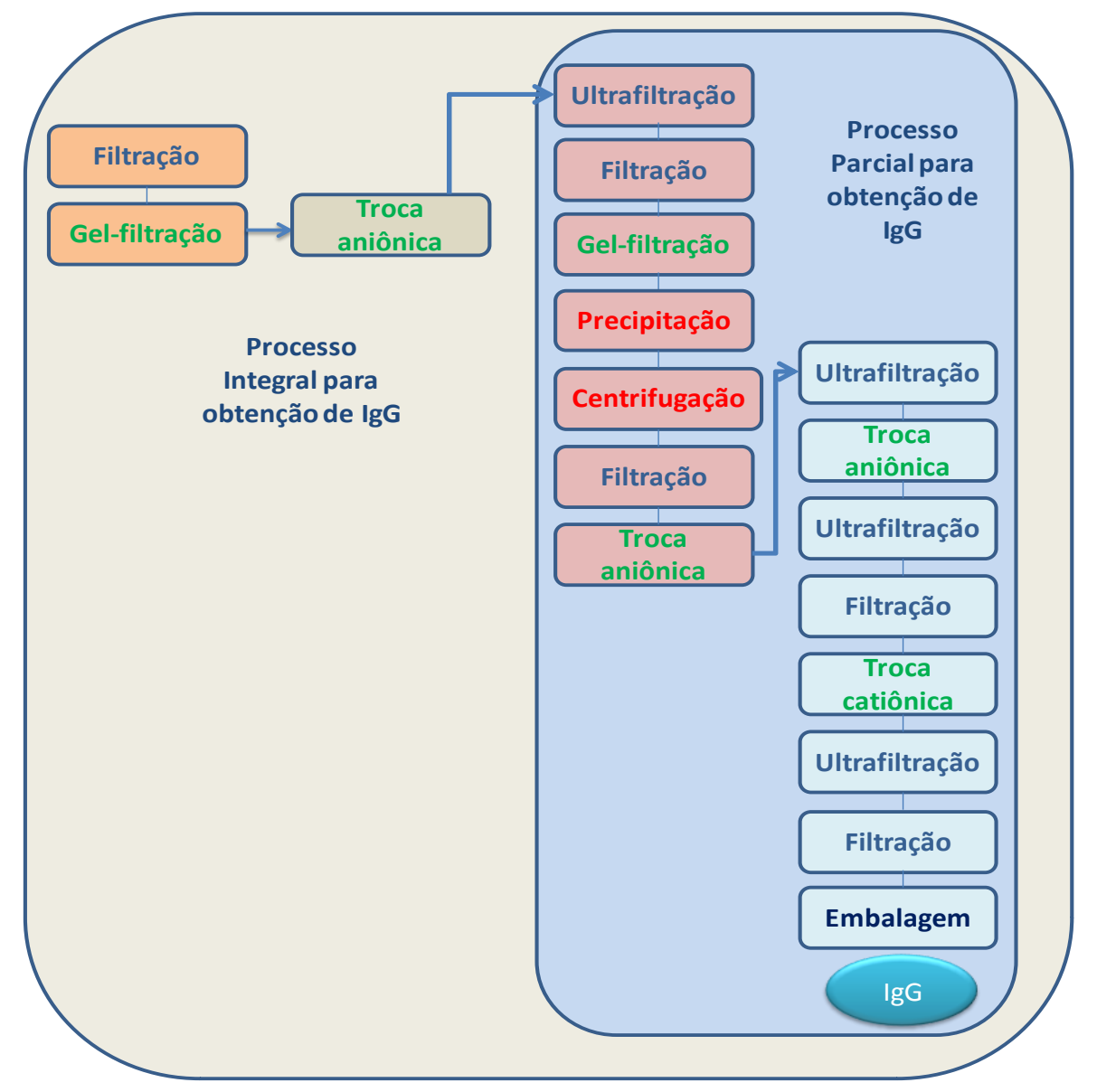

Figura 6 - Esquema do processo cromatográfico Integral e Parcial para purificação de lgG a partir de plasma humano. No processo parcial as duas primeiras cromatografias foram suprimidas. 
O processo completo inclui seis cromatografias, 4 ultrafiltrações e uma centrifugação. No processo parcial as duas cromatografias iniciais, nas quais seriam separados os fatores de coagulação, são eliminadas. O processo parcial será utilizado em purificações de lgG hiperimunes ou a partir de Plasma Comum (não o plasma fresco congelado do qual são separados também os fatores de coagulação).

Apresentamos abaixo uma série de cromatogramas ilustrando a sequência dos processos realizados na planta escala piloto.

\subsubsection{Etapa 1 - Cromatografia de gel filtração de plasma em resina Sepharose 4FF}

O plasma ( $25 \mathrm{~L}$ ) preparado como descrito em materiais e métodos foi aplicado em seis ciclos para gel filtração em coluna de $20 \mathrm{~L}$ de resina Sepharose $4 \mathrm{FF}$, recolhendo-se quatro frações. A primeira fração, F1-4FF, contem os multímeros de von Willebrand e FVIII, entre outros macromultímeros protéicos. Na F2-4FF estão as proteínas de massa molecular intermediária, como $\operatorname{lgM}$, enquanto na F3-4FF são separadas as proteínas majoritárias do plasma, albumina e lgG. Uma quarta fração é separada, considerada pobre nas proteínas de albumina e lgG.

A

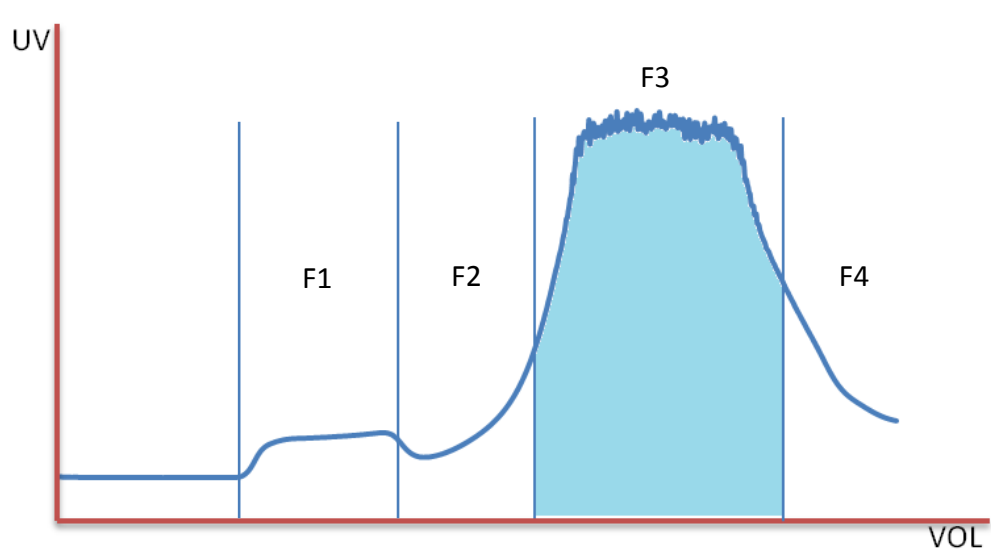

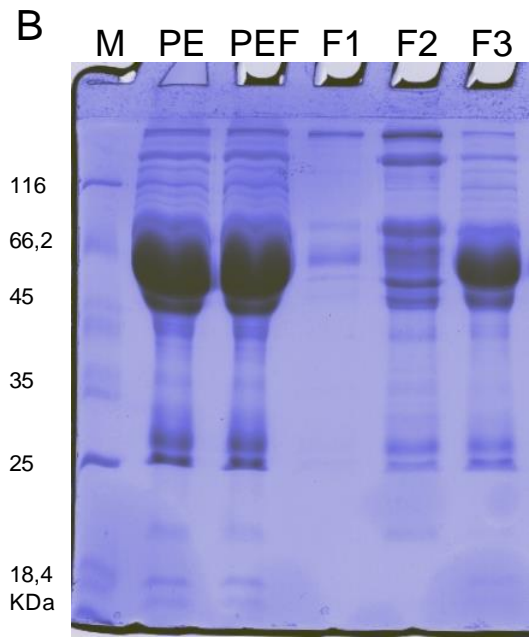

Figura 7 - A -Cromatograma do processo de gel filtração de plasma em resina Sepharose 4FF. A faixa em azul representa a fração que prossegue para purificação de lgG. B - SDS-PAGE (12\%) com amostras P - plasma, PF- plasma de entrada filtrado, e frações F1, F2, F3. 


\subsubsection{Etapa 2 - Cromatografia de troca aniônica}

Em volume aproximado de $80 \mathrm{~L}$, a F3-4FF sofreu ajuste para $\mathrm{pH} 7,0$ e foi aplicada à coluna de DEAE Sepharose, na qual as proteínas majoritárias albumina e IgG são eluidas no "flow through" e recuperadas na fração F1-DEAE, enquanto a maioria das proteínas dependentes de vitamina $\mathrm{K}$ são adsorvidas e eluidas posteriormente na F3-DEAE.
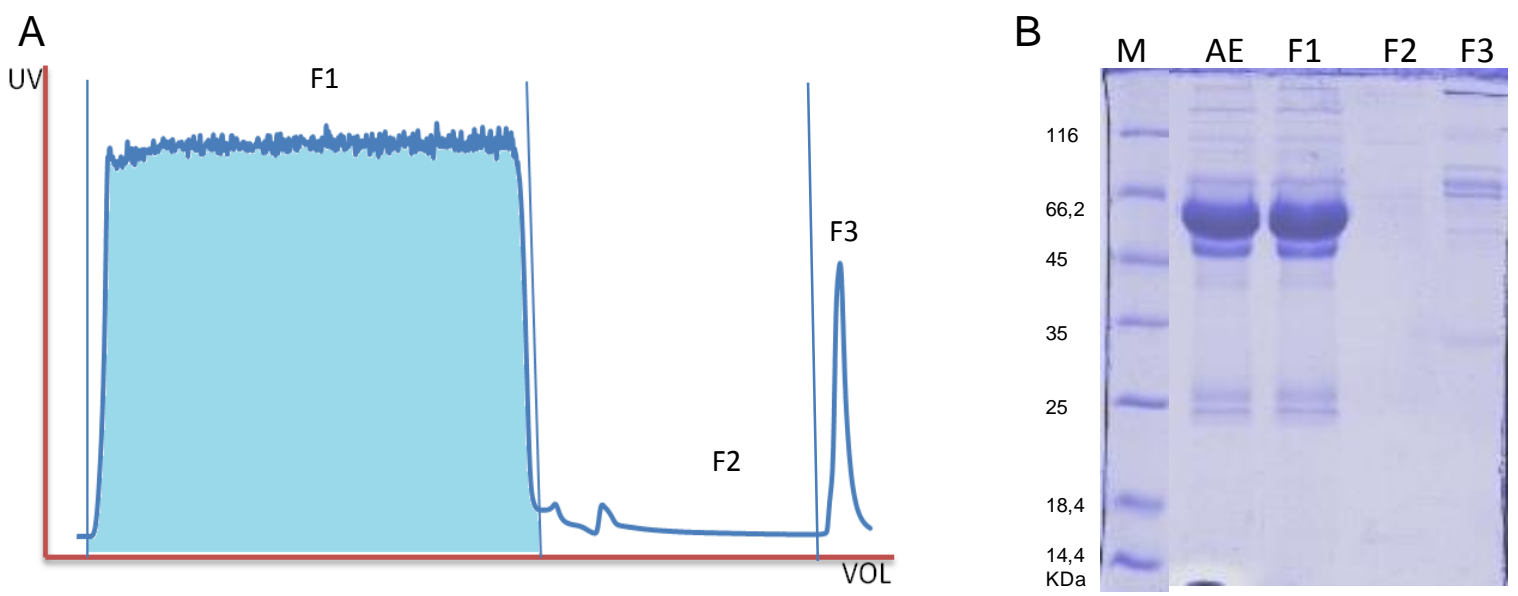

Figura 8 - A -Cromatograma do processo de troca iônica da fração F3-4FF em resina DEAE Sepharose. B - Amostras no SDS-PAGE: M- marcador de peso molecular, $A E$ - amostra de entrada (F3-4FF) e frações coletadas F1 (flow through), F2 (wash), F3 (eluição).

\subsubsection{Etapa 3 - Concentração por ultrafiltração}

A fração $\mathrm{F} 1-\mathrm{DEAE}$, com volume de $84 \mathrm{~L}$, sofre ultrafiltração tangencial em sistema de fibras ocas de $10 \mathrm{KDa}$ para a concentração para $25 \mathrm{~L}$.

4.1.4 Etapa 4 - Dessalinização por Gel Filtração, precipitação e separação de euglobulina

A fração F1-DEAE concentrada foi aplicada para gel filtração em resina Sephadex G-25 (VC = $20 \mathrm{~L}$ ) para remoção de sal, recuperando-se a fração F1-G25 com albumina e $\mathrm{lgG}$ em volume de aproximadamente $56 \mathrm{~L}$. A amostra foi acidificada iniciando a precipitação de euglobulina. A mistura foi mantida a $4^{\circ} \mathrm{C}$ por 4 a 16 horas. 
A euglobulina foi separada por centrifugação contínua, resultando em $24 \mathrm{~g}$ por litro de plasma, recuperando-se o sobrenadante contendo albumina e imunoglobulinas.
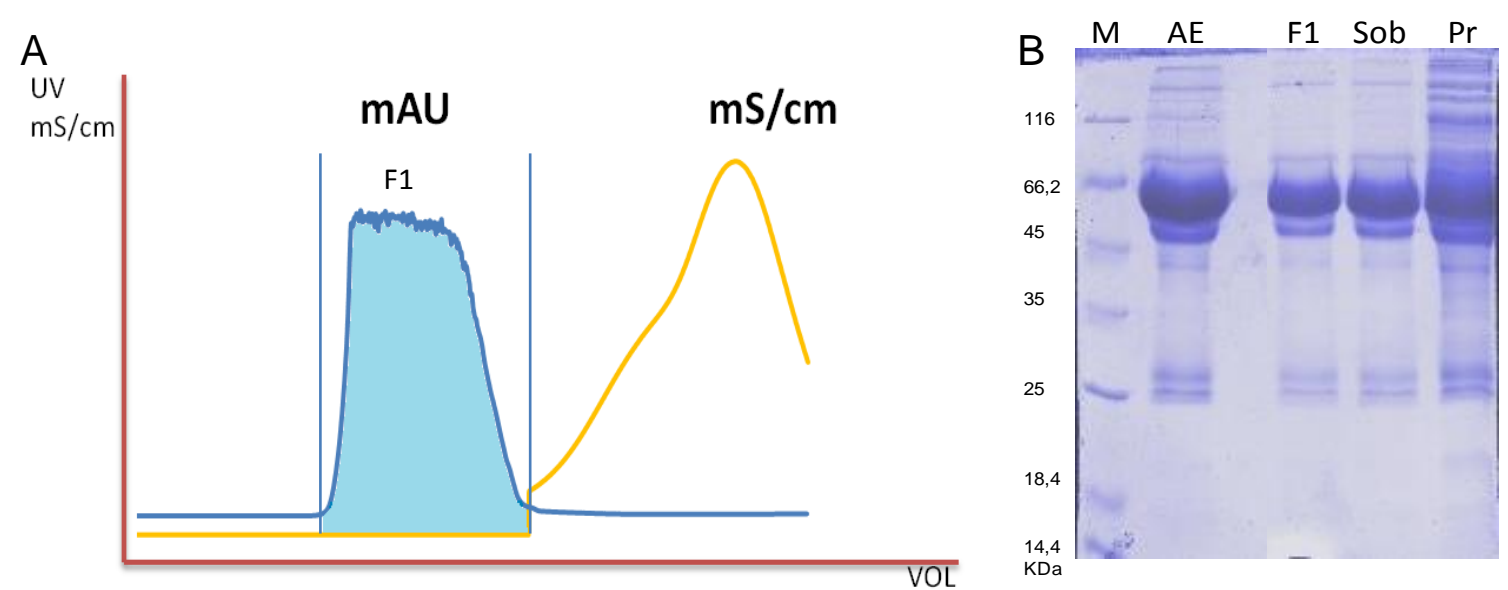

Figura 9 - A - Cromatograma da dessalinização da fração F1-DEAE concentrada, por gel filtração em resina Sephadex G25. B - Amostras no SDS-PAGE: AE- amostra de entrada, F1- fração F1-G25, Sob - Sobrenadante da centrifugação e Prprecipitado de euglobulina.

\subsubsection{Etapa 5 - Cromatografia de troca aniônica para separação de albumina}

O sobrenadante da centrifugação sofreu ajustes de condutividade e volume aproximado de $57 \mathrm{~L}$ foi aplicado em 10 ciclos para a segunda cromatografia de troca aniônica em resina DEAE Sepharose (cromatografia DEAE2). A proteína lgG foi recuperada na F1-DEAE2 ("flow through" + "wash") em aproximadamente 83 L, enquanto a albumina era adsorvida e posteriormente eluida na fração F2-DEAE2.

A

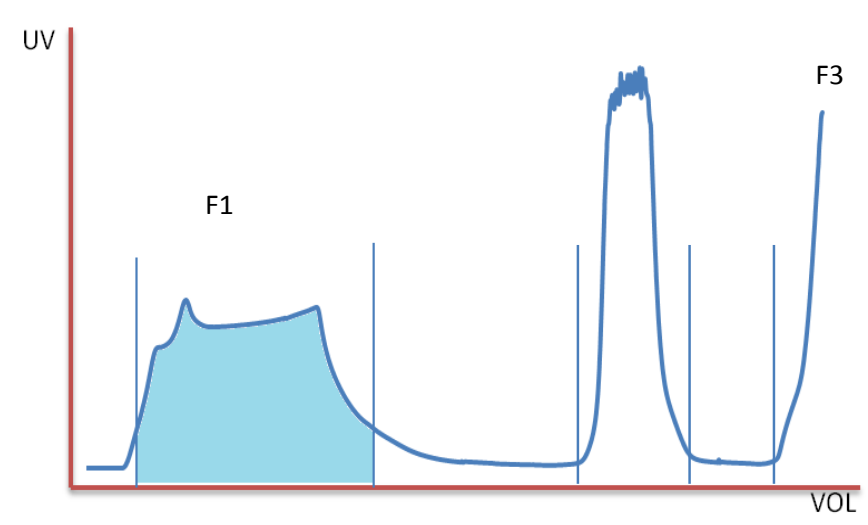

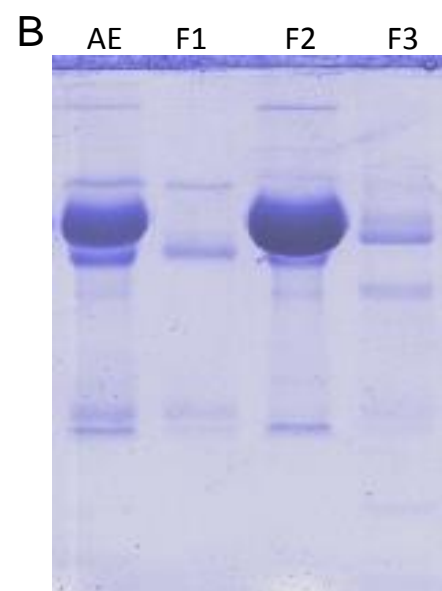

Figura 10 - A - Cromatograma do processo de troca iônica do sobrenadante recuperado da precipitação de euglobulina em resina DEAE Sepharose. B - Amostras no SDSPAGE: AE- amostra de entrada e frações coletadas F1, F2, F3. 


\subsubsection{Etapa 6 - Troca aniônica em Q Sepharose}

A fração $F 1-D E A E 2$, contendo lgG, foi concentrada por ultrafiltração, de $83 \mathrm{~L}$ para $25 \mathrm{~L}$, e aplicada para troca aniônica em resina Q Sepharose. Embora a Q-sepharose tambem seja uma resina de troca aniônica, o trocador aniônico amino quaternário é mais forte que o traçador dietilaminoetil da resina $D E A E$, permitindo uma condição em que a IgG seja eluida no "flow through", enquanto contaminantes fiquem adsorvidos. A IgG foi recuperado na F1-Q em aproximadamente 57 L. A F1-Q foi concentrada de $57 \mathrm{~L}$ para 2,6 para concentração $5 \%$, por ultrafiltração em hollow fiber de $10 \mathrm{kDa}$.
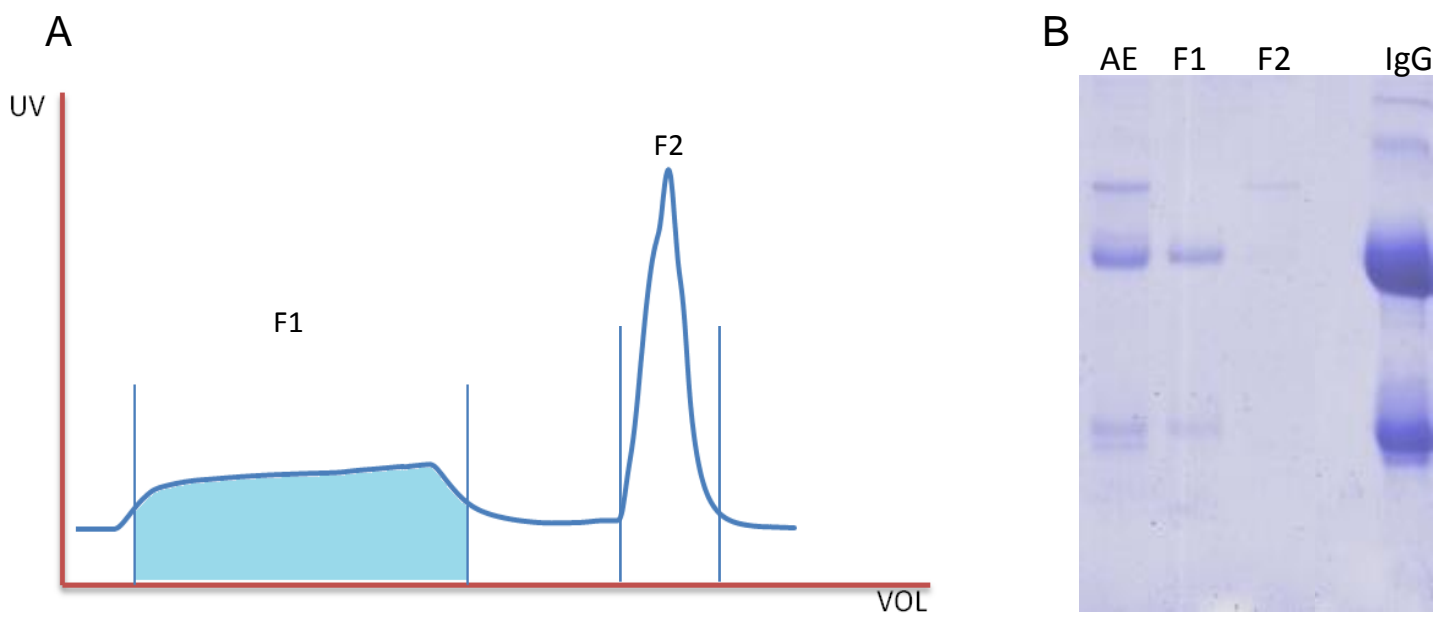

Figura 11 - A - Cromatograma do processo de troca iônica de F1-DEAE2 em resina $Q$ Sepharose. B - Amostras no SDS-PAGE: AE- amostra de entrada; F1 e F2 frações coletadas $F 1-Q, F 2-Q$, IgG - fração $F 1-Q$ concentrada..

\subsubsection{Etapa 7 - Inativação viral e cromatografia de troca catiônica}

A fração $F 1-Q$ concentrada foi adicionada de detergente Triton X-100 e solvente tri-nitro-butil-fosfato (TNBP) para inativação viral. Após 15 horas os reagentes foram removidos por cromatografia de troca catiônica em resina CM Sepharose. Nessa condição de cromatografia o lgG foi adsorvido, sendo eluído na fração F3-CM, em aproximadamente $8 \mathrm{~L}$. 
A

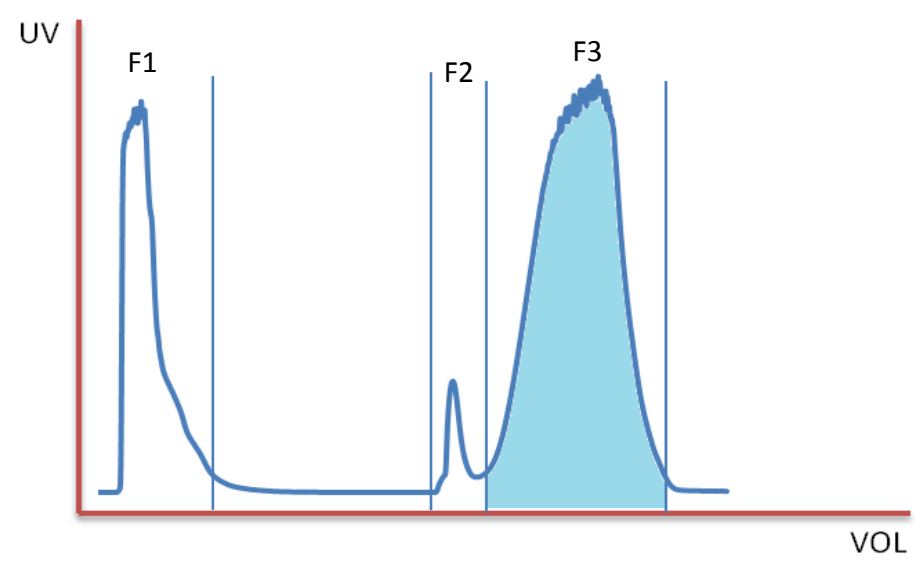

$\mathrm{B}$

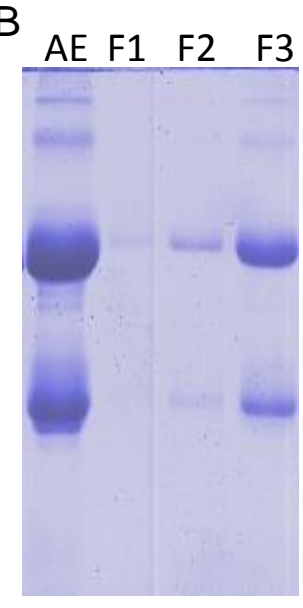

Figura 12 - A - Cromatograma do processo de troca catiônica da fração $F 1-Q$ em resina CM Sepharose, para remoção dos agentes de desinfecção viral. B - Amostras no SDS-PAGE: AE - amostra de entrada e F1, F2, F3 - frações coletadas F1-CM, F2-CM, F3-CM.

$\mathrm{Na}$ última etapa do processo de purificação de $\operatorname{lgG}$, a fração $\mathrm{F} 3-\mathrm{CM}$ foi concentrada por ultrafiltração/diafiltração de 8 para $2 \mathrm{~L}$, resultando em concentração aproximada de $5 \%$ da proteína e condutividade $0,5 \mathrm{mS} / \mathrm{cm}$.

A formulação final, constituída de $5 \%$ de $\operatorname{lgG}$ e $5 \%$ de sacarose como estabilizante, foi esterilizada por filtração em 0,22 $\mu \mathrm{m}$.

\subsubsection{Perfil protéico do lgG purificado}

Foram realizados seis processos na escala piloto, sendo 3 parciais, lotes 1,2 e 3 , e 3 completos, lotes 4,5 e 6 .

A Figura 13 ilustra os perfis protéicos das formulações finais dos lotes 3 e 5 . Como observados no gel, as amostras são consistentes, apresentando as cadeias leve e pesada de aproximadamente 35 e $55 \mathrm{kDa}$ respectivamente.

Os perfis protéicos não denotam diferenças entre as preparações de $\lg G$ obtidas por processo parcial, lote 3 , ou completo, lote 5 . 


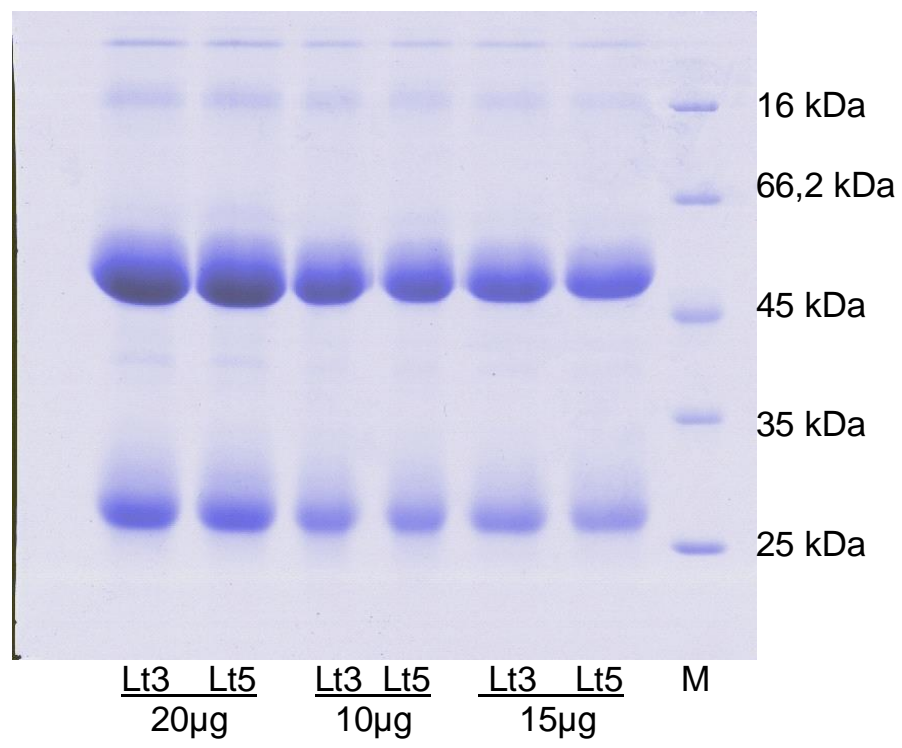

Figura 13 - Perfil proteico de amostras das formulações finais de $\lg G$, lote 3 , processo parcial, e lote 5, processo completo, realizados em escala piloto, com 20, 10 e $15 \mu \mathrm{g}$ de proteína em SDS-PAGE. M - marcador de peso molecular.

Com as recentes notificações de contaminação por FXI em preparações comerciais de lgG (ROEMISCH et al., 2011), sendo o Processo Cromatográfico (como aqui desenhado) um método novo de fracionamento de plasma, entendemos que seria importante avaliar a qualidade do produto final em relação à presença do referido contaminante. Neste contexto, procuramos investigar a atividade de FXI nas formulações finais de lgG obtidas na planta piloto. Além disso, buscamos rastrear, nas primeiras etapas cromatográficas do processo, em quais frações a proteína FXI era separada. Para tanto as primeiras etapas do processo de purificação de $\lg G$ foram montadas em escala de laboratório.

\subsection{Reprodução do processo de purificação de imunoglobulinas de plasma humano em escala de bancada.}

Reproduzimos em escala de bancada as duas etapas iniciais do processo industrial de purificação de $\lg G$, de maneira que o tempo de processo de cada etapa fosse mantido igual ao da escala industrial. 


\subsubsection{Etapa 1 - Cromatografia de gel filtração}

Volume de $420 \mathrm{~mL}$ de plasma, preparado como descrito em materiais e métodos (3.1.2), foi aplicado em coluna de $320 \mathrm{~mL}$ de Sepharose-4FF para gel filtração em 6 ciclos consecutivos de $70 \mathrm{~mL}$. Na Figura 14 está apresentado o cromatograma (UV $280 \mathrm{~nm}$ ) de um dos ciclos. O perfil foi reproduzido em todos os ciclos e foi semelhante aos obtidos na escala piloto.

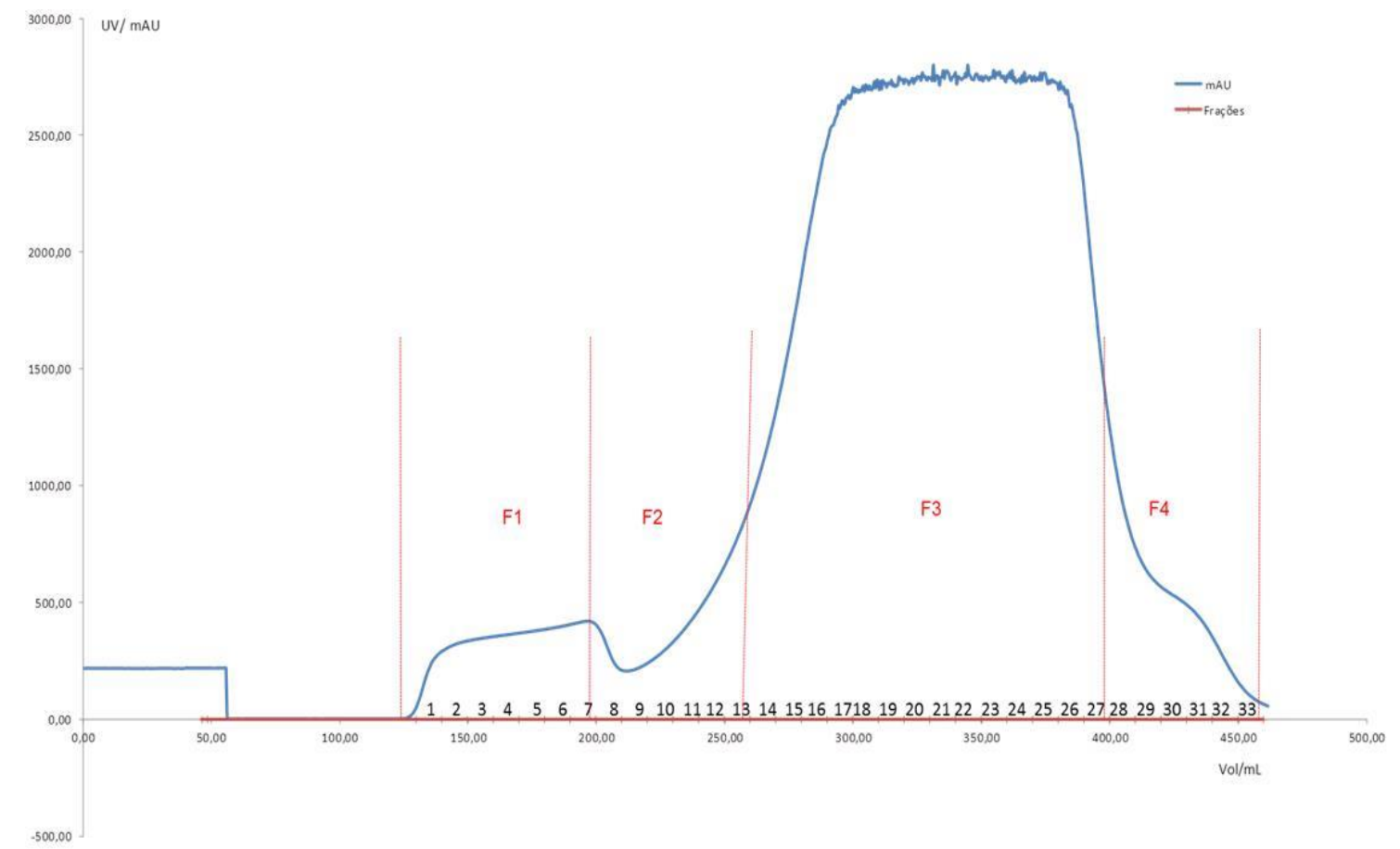

Figura 14 - Cromatograma (UV $280 \mathrm{~nm}$ ) representativo da separação de proteínas de plasma humano em resina Sepharose 4FF. São indicadas as 4 frações normalmente separadas no processo.

As quatro frações cromatográficas indicadas no cromatograma de plasma em resina Sepharose 4-FF (Figura 14) são separadas no processo industrial enriquecidas nas proteínas de interesse.

- Fração F1-4FF é rica em proteínas ou complexos protéicos de alta massa, maior que $10^{6} \mathrm{Da}$, como FVIII plasmático ligado a fator de von Willebrand (FvW), multímeros complexos de FvW, fibrinogênio e fibronectina, além de outras proteínas;

- Fração F2-4FF contém proteína de peso molecular intermediário, como $\operatorname{lgM}$ e complemento; 
- Fração F3-4FF contém a maioria das proteínas plasmáticas, incluindo fatores de coagulação dependentes de vitamina $\mathrm{K}$, IgG, albumina e também contém IgM e vW em concentrações menores (KAERSGAARD; BARINGTON, 1998);

- Fração F4-4FF O perfil cromatográfico reproduz o ombro que indica ou o enriquecimento em proteínas de menor massa, as quais seriam eluídas com atraso, em relação às proteínas majoritárias albumina e lgG. É uma fração descartada no processo, porém de interesse para futuras investigações para identificação de novos produtos potenciais.

4.2.2 Segunda etapa de purificação - Cromatografia da F3-4FF em resina DEAE Sepharose

O volume de $980 \mathrm{~mL}$ de F3-4FF foi aplicado diretamente em $25 \mathrm{~mL}$ de coluna DEAE-Sepharose. A maior parte das proteínas IgG e albumina foi eluída no "Flow through", em volume de $1 \mathrm{~L}$ (F1-DEAE) (Figura 15). A coluna foi lavada com tampão de equilíbrio e as proteínas dependentes de vitamina $\mathrm{K}$ foram eluídas em $24 \mathrm{~mL}$, F3DEAE.

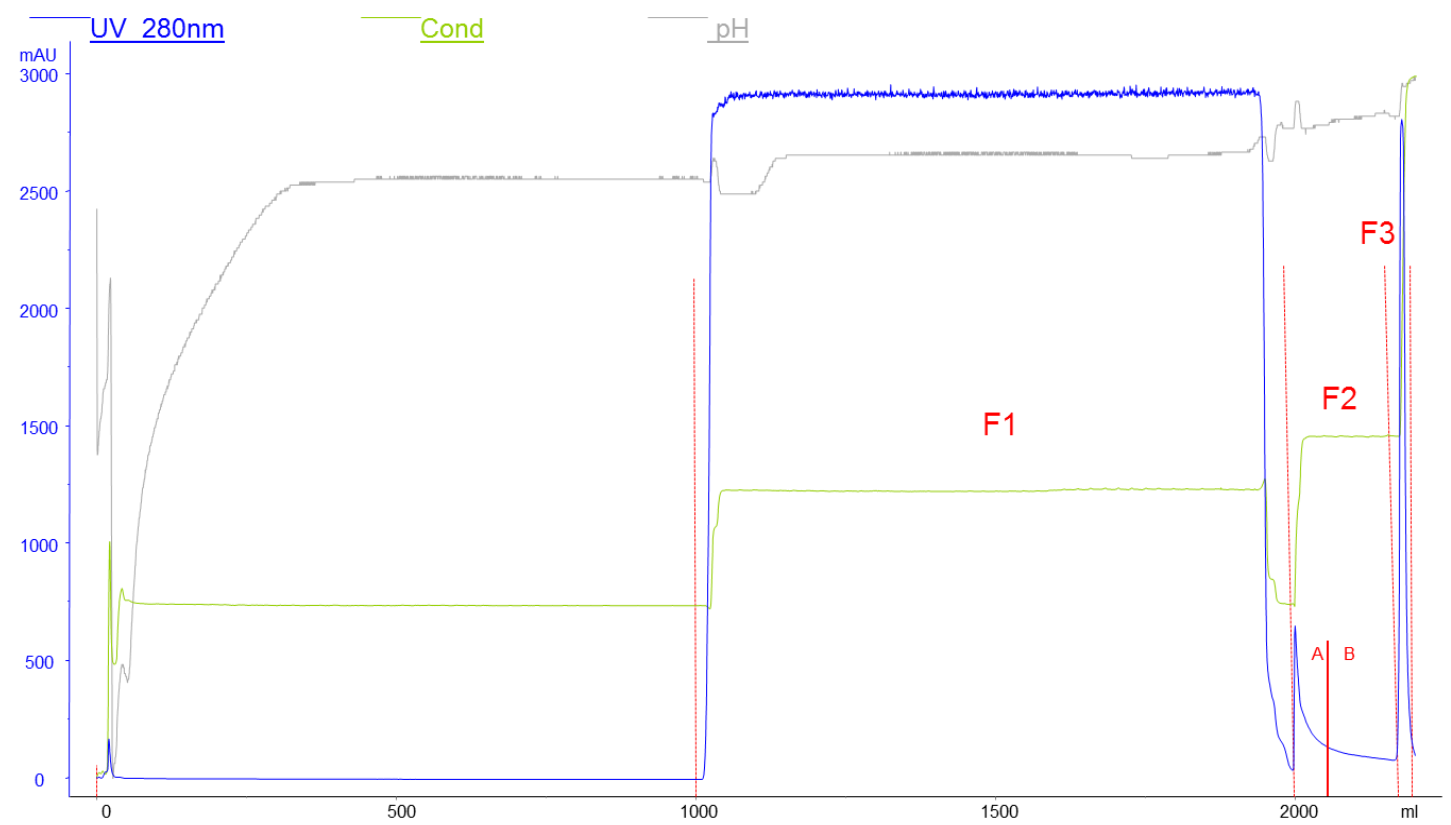

Figura 15 - Cromatograma (UV $280 \mathrm{~nm}$ ) da separação de proteínas da fração F3-4FF em resina DEAE-Sepharose. As frações coletadas estão indicadas, F1, F2a, F2b e F3. 
A Tabela I apresenta algumas características das frações da cromatografia do plasma por gel filtração em Sepharose 4FF e das frações coletadas na segunda cromatografia, fração F3-4FF em resina DEAE.

Tabela I - Volumes das frações das duas cromatografias: plasma em Sepharose 4FF e fração F3-FF em resina DEAE.

\begin{tabular}{|c|c|c|c|c|}
\hline Frações & $\begin{array}{c}\text { Volume } \\
\text { por ciclo } \\
(\mathrm{mL})\end{array}$ & $\begin{array}{l}\text { Volume total } \\
\qquad(\mathrm{mL})\end{array}$ & $\begin{array}{l}\text { Proteínas } \\
\text { separadas }\end{array}$ & $\begin{array}{l}\text { Concentração } \\
\text { relativa** }\end{array}$ \\
\hline Plasma de entrada & 70 & 420 & ----- & $1 x$ \\
\hline F1-4FF & 75 & 450 & FVIII, vW & $0,9 \times$ \\
\hline F2-4FF & 57 & 342 & IgM conc. & $1,2 \times$ \\
\hline F3-4FF & 164 & 984 & $\begin{array}{c}\text { Alb, IgG, } \\
\text { Depen. Vit-K. }\end{array}$ & $0,43 x$ \\
\hline F4-4FF & 38 & 228 & ----------- & --- \\
\hline $\begin{array}{c}\text { F3-4FF } \\
\text { entrada DEAE }\end{array}$ & - & 980 & $\begin{array}{c}\text { Alb, lgG, } \\
\text { Depen-Vit-K }\end{array}$ & 0,43 \\
\hline $\begin{array}{c}\text { F1-DEAE } \\
\text { "Flow Through" }\end{array}$ & - & 1000 & Alb, lgG & 0,42 \\
\hline F2-DEAEa & - & 35 & $?$ & 12 \\
\hline F2-DEAEb & - & 137 & ---------- & 3,1 \\
\hline $\begin{array}{l}\text { F3-DEAE } \\
\text { eluição }\end{array}$ & - & 24 & Depen. Vit-K & 18 \\
\hline
\end{tabular}

* Proteínas esperadas na fração e

** Concentração em relação ao plasma aplicado na cromatografia. 
4.2.3 Análise das frações eluídas da cromatografia em resina DEAE Sepharose por SDS PAGE

Amostras das frações das duas cromatografias foram aplicadas para análise em SDS-PAGE (Figura 16).

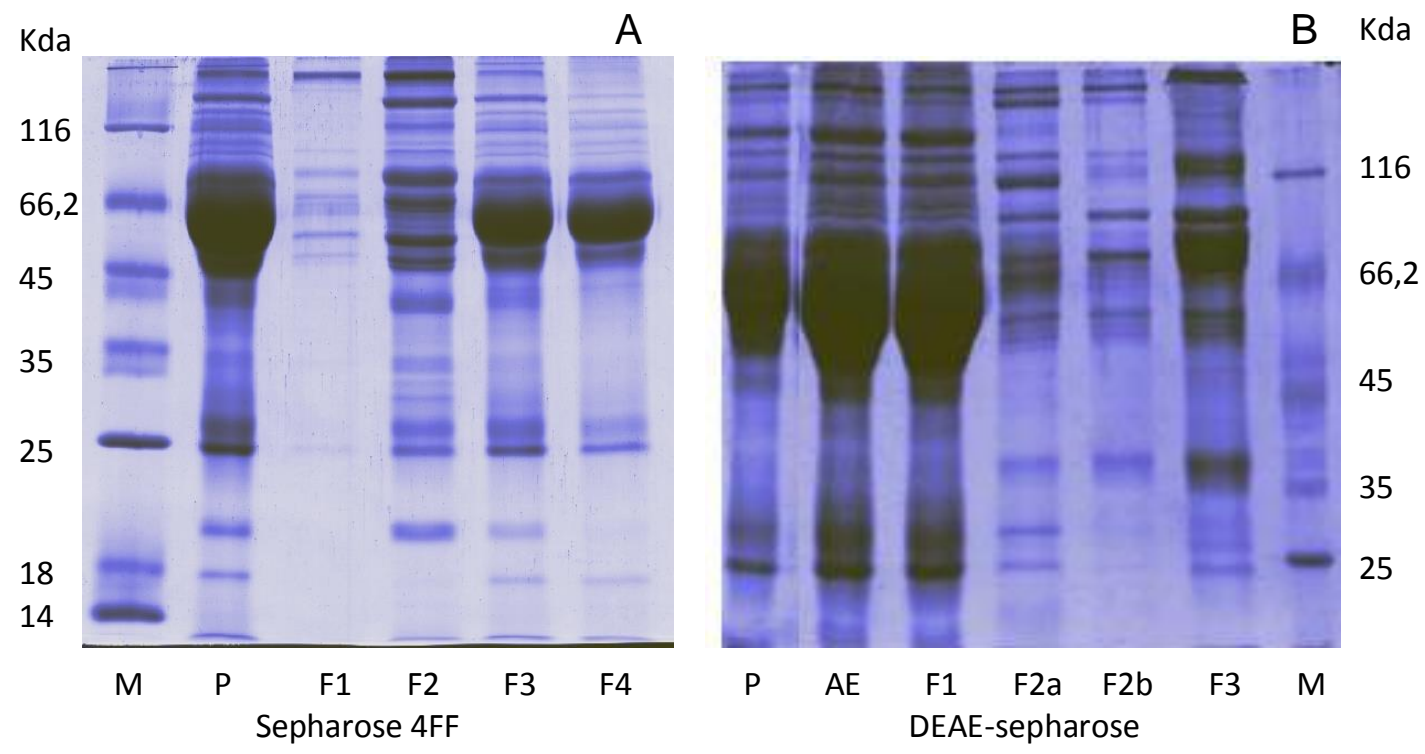

Figura 16 - Análise do perfil proteico das frações das cromatografias de plasma em Sepharose 4FF e de F3-4FF em coluna de DEAE-Sepharose, por SDS-PAGE. A - Amostras das frações de Sepharose 4FF e volumes relativos: $P$ plasma $(0,6$ $\mu \mathrm{L})$; F1-4FF (12 $\mu \mathrm{L})$; F2-4FF $(12 \mu \mathrm{L})$; F3-4FF $(0,6 \mu \mathrm{L})$; F4-4FF $(12 \mu \mathrm{L})$.

B - Amostras de frações da cromatografia em DEAE Sepharose: P-Plasma filtrado inicial $(0,4 \mu \mathrm{l}) ; \mathrm{AE}$ - Amostra de entrada F3-4 FF $(2 \mu \mathrm{l})$; F1-DEAE $(2 \mu \mathrm{l})$; F2a-DEAE $(4 \mu \mathrm{l})$; F2b-DEAE $(4 \mu \mathrm{l})$; F3-DEAE $(2 \mu \mathrm{l})$; M- Marcador $(4 \mu \mathrm{l})$. Coloração por Coomassie blue.

\subsection{Análise da presença de FXI em amostras de IgG produzidas na planta piloto e nas frações das duas cromatografias realizadas em escala de bancada, por Western Blot.}

Amostras das formulações de lgG produzidas na escala piloto, lotes 1, 3, 5 e 6 foram analisadas por western blot quanto à presença de $\mathrm{FXI}$, usando anticorpo monoclonal contra a cadeia pesada de FXI (Figura 17). Amostras das frações coletadas das duas cromatografias realizadas em escala de bancada (plasma em Sepharose 4FF e F3-4FF em DEAE-Sepharose), tambem foram analisadas por western blot (Figura 17). 


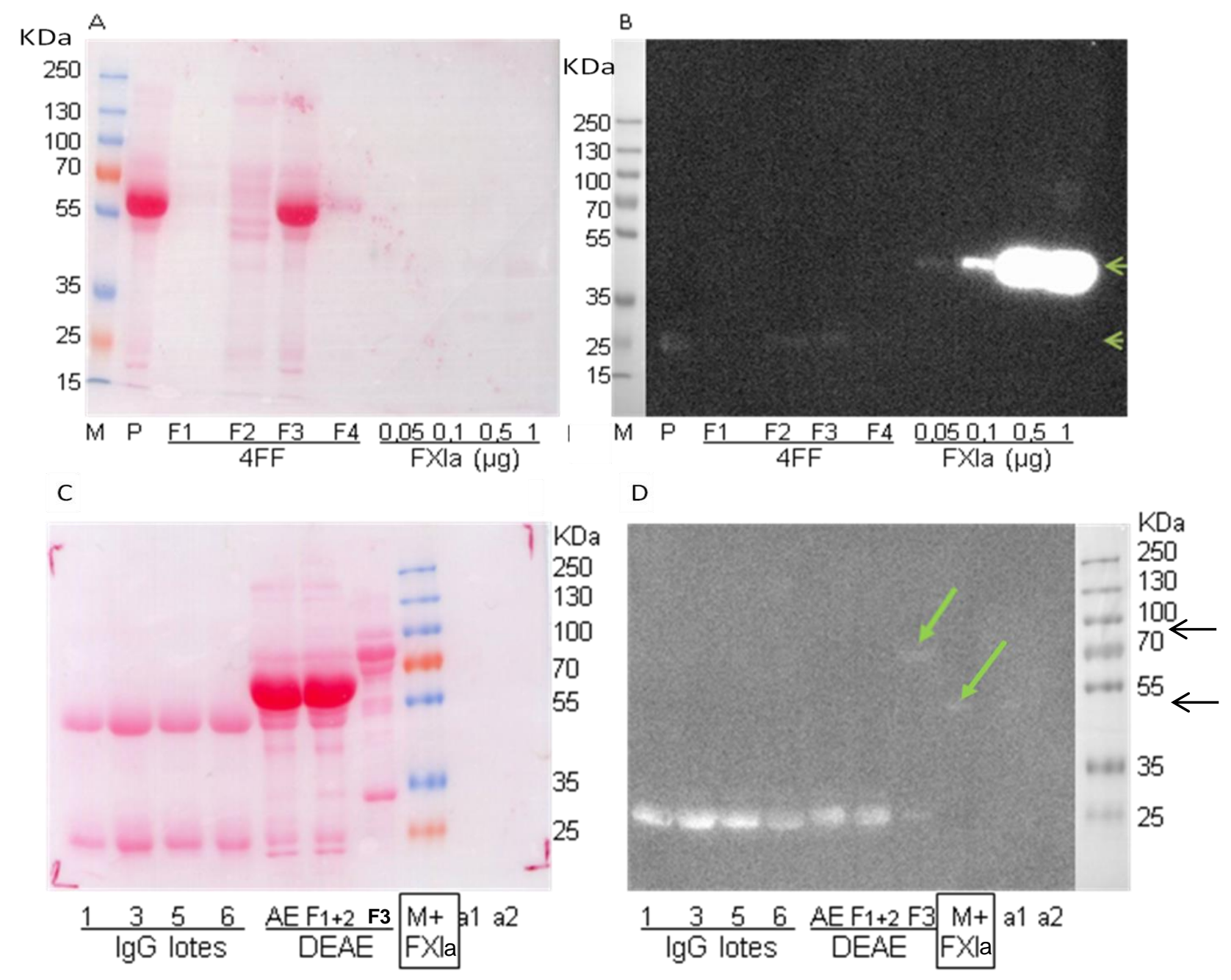

Figura 17 - Análise da presença de FXI em frações de cromatografia por Western blot.

A e B - Amostras das frações da cromatografia de plasma em resina Sepharose 4FF foram separadas por SDS-PAGE e as proteínas transferidas para membranas de PVDF. . C e D - Amostras de lotes de preparações de IgG em escala piloto e amostras de frações da cromatografia de F3-4FF em resina DEAE-Sepharose. A e C- membranas coradas com Ponceau para análise da transferência das proteínas; B e D Reconhecimento de FXI nas membranas reveladas por substrato quimioluminescente. Os volumes equivalentes de amostra aplicados estão indicados entre parênteses. Amostras em A e B: Mmarcador $(3 \mu \mathrm{l})$, P- plasma de entrada $(0,6 \mu \mathrm{l})$, F1-4FF $(30 \mu \mathrm{l})$; F2-4FF $(25 \mu \mathrm{l})$; F3-4FF (1,2 $\mu \mathrm{l})$; F4-4FF (12 $\mu \mathrm{l})$; FXla comercial $(0,05,0,1,0,5$ e $1 \mu \mathrm{g})$. Amostras em C e D: IgG (solução 5\%) da planta piloto, lotes 1, 3, 5, $6(0,5 \mu \mathrm{l}), \mathrm{AE}$ amostra de entrada na DEAE Sepharose (F3-4FF) $(2 \mu \mathrm{l}) ; \mathrm{F}_{1+2^{-}} \mathrm{F} 1$-DEAE $(2 \mu \mathrm{l})+$ F2-DEAE $(8 \mu \mathrm{l})$; El- Eluição F3-DEAE; M- Marcador $(3 \mu \mathrm{l})+0,1 \mu \mathrm{g}$ de FXla comercial. a1 e a2 - FXla comercial (50 ng e $25 \mathrm{ng}$ ). Setas pretas indicam massa molecular de FXI (80 kDa) e FXla (cadeia pesada 50kDa). Setas verdes indicam tênues bandas reveladas (proteína com massa aproximada $65 \mathrm{kDa}$ ) e a cadeia pesada de FXla.

As amostras foram aplicadas em SDS-PAGE e as proteínas transferidas para membranas de PVDF. A transferência das proteínas para as membranas foi avaliada por coloração com Ponceau (Figuras 17 A e 17C). Após o bloqueio, as membranas 
foram expostas ao anticorpo anti-FXI (monoclonal feito em camundongo) e ao anticorpo secundário anti-FC de camundongo conjugado com peroxidase. A ligação dos anticorpos foi detectada por substrato quimioluminescente de peroxidase. Foram utilizadas amostras de FXI comercial como padrão (Figuras 17B e 17D).

Avaliamos que, considerando a baixa concentração de FXI no plasma ( 5 $\mu \mathrm{g} / \mathrm{mL}$ ) e o pequeno volume de amostras de plasma que pode ser aplicado no gel $(1 \mu \mathrm{L})$, estávamos abaixo do limite de detecção da molécula, mesmo utilizando a metodologia sensível de quimiluminescência na revelação do western (ECL). Observa-se na Figura 17B que 50 ng do FXla comercial é revelado como uma banda tênue.

Observa-se na Figura 17B que não houve reconhecimento de FXI em nenhuma das frações cromatográficas e nem mesmo na amostra de plasma, mas somente nas amostras com FXla comercial, revelando-se a banda da cadeia pesada de $50 \mathrm{kDa}$.

Nas amostras de plasma e nas frações F2, F3 e F4 eluídas da cromatografia em Sepharose 4FF observa-se uma banda de massa aproximada de $25 \mathrm{KDa}$, correspondente à cadeia leve de lgG. Questionamos se essa banda seria devida a um reconhecimento espúrio do anti-FXI a um fragmento protéico inespecífico, ou ainda se o anticorpo estaria revelando fragmentos menores da molécula de FXI. Essa hipótese foi testada no laboratório, verificando-se que na ausência do anticorpo primário essa banda não é revelada e que em presença de anticorpos de camundongo específicos contra outros antígenos, a banda é visualizada (dados não mostrados). Esse e outros dados nos levam a crer que ocorre ligação espúria de anticorpos de camundongos com a cadeia leve de lgG.

Amostras de preparações de $\lg G$ e de frações da cromatografia em resina DEAE-Sepharose foram analisadas quanto à presença de FXI por western blot (Figura 17D). No ensaio verificamos novamente o reconhecimento, provavelmente espúrio, do anticorpo primário sobre a banda de $25 \mathrm{Kda}$, provavelmente ligação à cadeia leve de lgG, como observado na Figura 17B.

No western blot (Figura 17D), podemos verificar uma banda tênue na fração F3-DEAE (eluição) enriquecida nas proteínas dependentes de vitamina $\mathrm{K}$.

Nas proteínas dependentes de vitaminas $\mathrm{K}$ existe um domínio GLA, onde ocorrem carboxilações e por isso um acúmulo de cargas negativas que contribuem para ligação à resina DEAE-Sepharose. Essas proteínas são eluidas com aumento da condutividade e são recuperadas na fração de eluição. O FXI não possui domínio 
GLA, mas a banda no western blot sugere que a proteína seja eluída juntamente com as proteínas dependentes de vitamina K. Entretanto a altura dessa banda não é consistente com o tamanho do $\mathrm{FXI}(80 \mathrm{kDa})$, nem com o tamanho da cadeia pesada do FXla (50 kDa) (Figura 17D), mas em torno de $60 \mathrm{kDa}$. Assim, esse ensaio de western blot não foi conclusivo.

\subsection{Dosagem de atividade de FXI nas frações de cromatografia de plasma}

Dosagens de atividade de FXI foram feitas por medida de tempo de coagulação usando plasma deficiente em FXI. O plasma deficiente era complementado com amostras de plasma normal ou com as amostras das frações das cromatografias.

Os tempos de coagulação foram medidos usando coagulômetro ou usando um equipamento leitor de placa de ELISA (Enzyme linked immunosorbent assay) que permite a medida da cinética de coagulação por absorbância.

O ensaio de coagulação em placa de ELISA foi estabelecido e mostrou-se consistente com os dados medidos no coagulômetro (dados não mostrados). Descrevemos aqui os dados coletados usando o leitor de placa de ELISA.

A reação de coagulação medida em placa de ELISA é preparada da mesma maneira que a medida por coagulômetro, resumidamente: as amostras são adicionadas ao plasma deficiente em $\mathrm{FXI}$, a mistura é ativada por cefalina/ácido elágico (Actin), seque a recalcificação do sistema e inicia-se a medida de absorbância para acompanhar a cinética de desenvolvimento do coágulo. Na placa de ELISA a diferença é que se trabalha com metade dos volumes usados no coagulômetro e é possível fazer diversas dosagens simultaneamente. O equipamento leitor de ELISA utilizado permite agitação da placa e sua manutenção a $37{ }^{\circ} \mathrm{C}$. A cinética de coagulação foi acompanhada por leituras de absorbância em $405 \mathrm{~nm}$ a cada 4 segundos.

A Figura 18 mostra as curvas das cinéticas de coagulação do plasma deficiente em FXI adicionado de diferentes diluições de plasma normal.

O tempo de coagulação de cada amostra corresponde ao valor da absorbância média em cada curva, o ponto de inflexão foi calculado usando o programa SoftMax. (De fato o programa retorna o tempo para atingir metade da absorbância, descontando a absorbância inicial). 


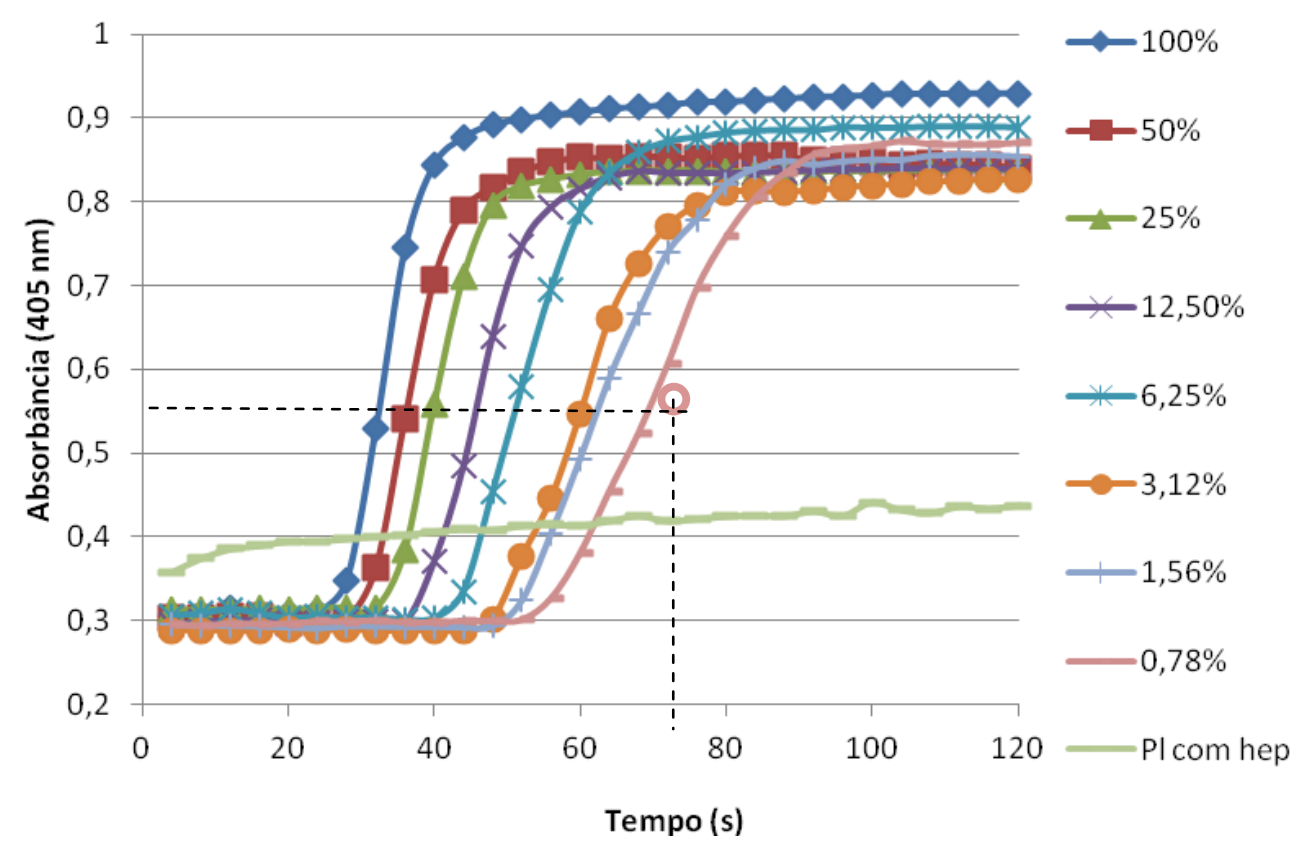

Figura 18 - Dosagem de FXI por tempo de coagulação (aPTT) em amostras de plasma normal em diferentes diluições. As reações em placa de ELISA foram preparadas com as diluições de plasma indicadas na figura. As reações foram iniciadas simultaneamente imediatamente após adição de solução de cálcio. As leituras de absorbância $405 \mathrm{~nm}$ foram feitas automaticamente a cada 4 segundos. PI com hep é plasma com heparina. Não se observa formação de coagulo nessa amostra. $O$ tempo de coagulação foi considerado como o ponto de inflexão de cada curva (tempo da $1 / 2$ da $\triangle A$ Abs) (o circulo e as linhas tracejadas ilustra o ponto tomado por tempo de coagulação para a curva de mais alta diluição). Os tempos são computados com auxilio do programa SoftMax.

Os tempos de coagulação adquiridos para as amostras de plasma estão apresentados na tabela II. A partir dos tempos de coagulação, estabelecemos a curva de Log $t$ ( $t$ = tempo de coagulação) em função do Log da concentração de plasma. Assim os tempos de coagulação são correlacioandos com a concentração de plasma de maneira bilogaritmica para estabelecer uma equação linear e possibilitar o cálculo do valor de atividades nas amostras em teste. 
Tabela II - Tempos de coagulação do plasma humano sem heparina, medidos em leitor de ELISA.

\begin{tabular}{cccc}
\hline$\%$ Plasma & Log (\%PI) & $\begin{array}{c}\text { Tempo } \\
\text { Coagulação (s) }\end{array}$ & Log tempo \\
\hline 100 & 2 & 29,64 & 1,47 \\
\hline 50 & 1,69 & 32,9 & 1,51 \\
\hline 25 & 1,40 & 36,43 & 1,56 \\
\hline 12,5 & 1,10 & 42,15 & 1,62 \\
\hline 6,25 & 0,80 & 48,66 & 1,68 \\
\hline 3,12 & 0,49 & 56,42 & 1,75 \\
\hline 1,56 & 0,19 & 59,44 & 1,77 \\
\hline 0,78 & $-0,109$ & 66,93 & 1,82 \\
\hline
\end{tabular}

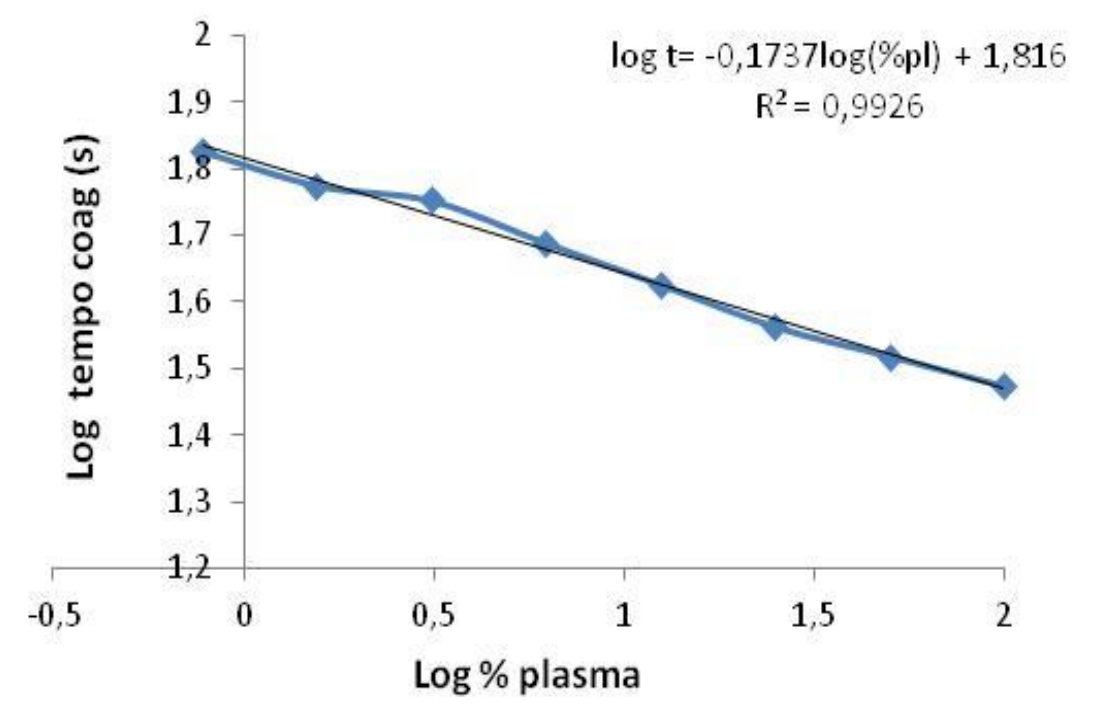

Figura 19 - Relação entre tempo de coagulação e concentração de plasma normal. A curva bilogaritmica permite estabelecer uma relação linear dos dados de diluições do plasma e é usada como uma curva padrão. A equação da reta assim determinada é usada para os cálculos de atividade nas frações cromatográficas.

As atividades de coagulação de cada mistura de plasmas podem variar e por isso, amostras do plasma a ser utilizado em cada experimento eram retiradas antes da adição de heparina para estabelecer a curva padrão daquele experimento. A equação da reta determinada era utilizada para cálculo de concentração de FXI nas amostras cromatográficas.

Os ensaios de dosagem de atividade de FXI nas frações cromatográficas e em amostras de lotes de lgG produzidos na planta piloto foram realizados por 
cinética de coagulação. Os tempos medidos nas cinéticas estão apresentados na tabela III.

Nesse ensaio a equação da curva padrão foi estabelecida como:

$$
Y=a x+b \rightarrow \log t=-0,139 \log (\% p l)+1,9181\left(R^{2}=0,9936\right)
$$

Para o cálculo de atividades nas amostras os valores log de tempo são inseridos na equação e os resultados apresentados como atividade em dada porcentagem de plasma.

O valor de atividade é multiplicado pelo volume da fração, calculando-se a atividade na fração. Calculamos ainda a porcentagem de atividade na fração em relação à atividade na amostra de entrada da cromatografia.

A amostra de entrada foi considerada com $100 \%$ de atividade e as demais são medidas como porcentagem da inicial.

Tabela III - Tempos de coagulação de amostras das frações cromatográficas das preparações de lgG (lotes piloto) medidos em leitor de ELISA.

\begin{tabular}{cccccccc}
\hline Amostras & $\begin{array}{c}\text { Tempo } \\
(\mathbf{s})\end{array}$ & Log T & $\begin{array}{c}\text { Log } \\
\text { (\%plsm) }\end{array}$ & \% Ativ & $\begin{array}{c}\text { Volume } \\
\text { fração }\end{array}$ & $\begin{array}{c}\text { Atividade } \\
\text { fração }\end{array}$ & $\begin{array}{c}\text { \% Atividade } \\
\text { da entrada }\end{array}$ \\
\hline Plasma & 50 & 1,70 & 2,03 & 105,93 & 420 & 44492 & 100,00 \\
\hline F1-4FF & 75 & 1,88 & 0,74 & 5,49 & 450 & 2471 & 5,55 \\
\hline F2-4FF & 71 & 1,85 & 0,91 & 8,19 & 342 & 2802 & 6,30 \\
\hline F3-4FF & 69 & 1,84 & 1,01 & 10,20 & 984 & 10037 & 22,56 \\
\hline F1-DEAE & 48 & 1,68 & 2,19 & 154,04 & 228 & 35121 & 78,94 \\
\hline F2-DEAEa & 68 & 1,83 & 1,05 & 11,23 & 1000 & 11227 & 25,24 \\
\hline F2-DEAEb & 69 & 1,84 & 1,02 & 10,42 & 35 & 364 & 0,82 \\
\hline F3-DEAE & 80 & 1,90 & 0,53 & 3,37 & 137 & 461 & 1,04 \\
\hline
\end{tabular}


O gráfico da Figura 20 ilustra as atividades de FXI nas frações da cromatografia de plasma em Sepharose-4FF e cromatografia da F3-4FF em resina DEAE Sepharose.

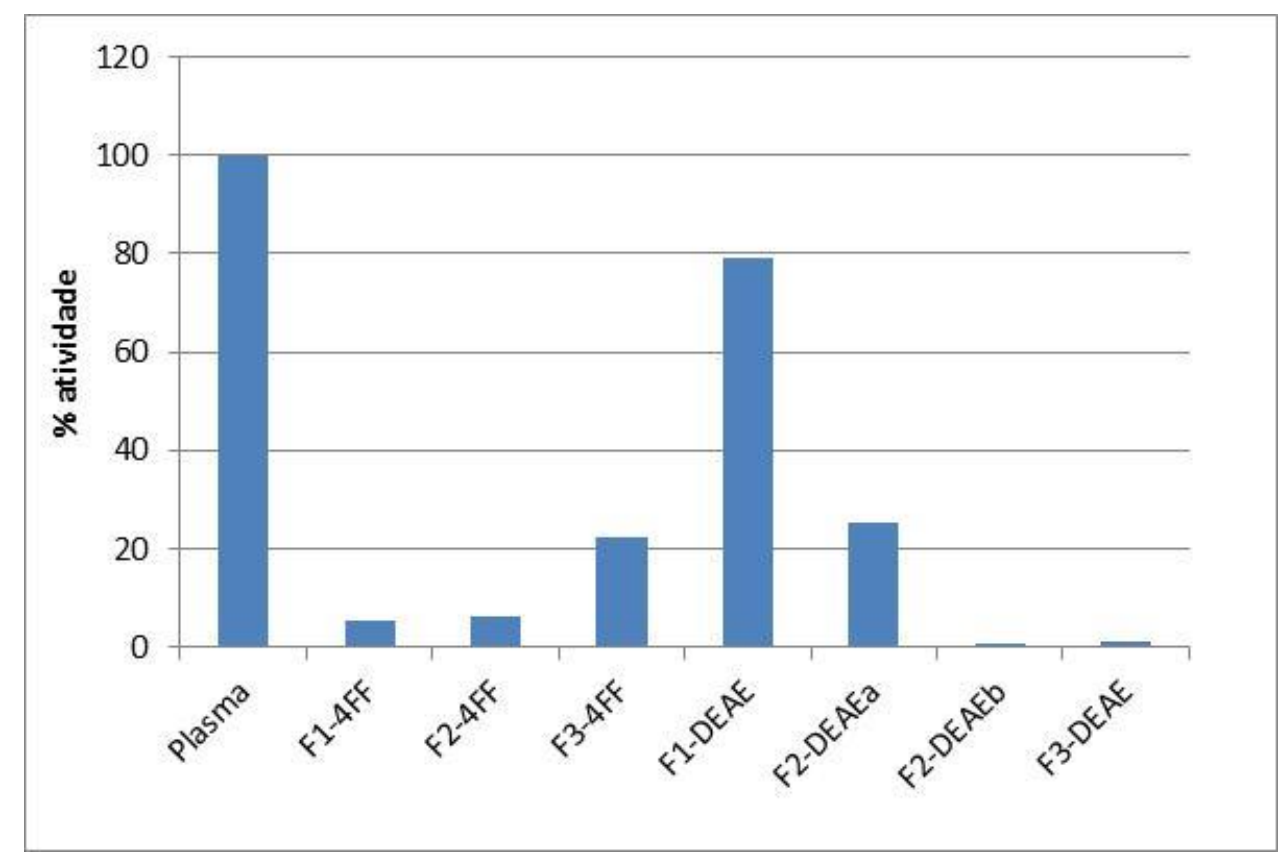

Figura 20 - Atividade de FXI nas frações da cromatografia de plasma em resina Sepharose 4FF e DEAE Sepharose. As dosagens foram feitas por método de coagulação, usando ensaio em placa de ELISA. Os valores foram calculados como descrito acima.

Observa-se que a atividade de FXI não foi encontrada nas frações da primeira cromatografia, porém foi encontrada em frações da segunda cromatografia. Isso certamente está relacionado com a presença de heparina nas frações da Sepharose 4FF. De fato, não é possível medir atividade de FXI em plasma heparinizado pelo método de coagulação (Figura 18). A heparina liga-se em AT-III aumentando a atividade do inibidor em 1000 vezes, impedindo a coagulação.

A fração F1-DEAE apresentou alta atividade de coagulação indicando que o FXI não é adsorvido à resina.

É interessante notar o desaparecimento do efeito da heparina, permitindo recuperar a atividade de FXI na fração da segunda cromatografia. Podemos supor que a heparina, por ter muitas cargas negativas, tenha sido adsorvida na coluna aniônica (DEAE), não mais interferindo na dosagem de FXI. De fato, existem protocolos de purificação de heparina por adsorção em resinas de troca aniônica (SANTOS et al., 2014). 
A atividade de $\mathrm{FXI}$ foi também dosada em amostras de diferentes lotes de lgG $5 \%$ preparados na planta piloto. Nos lotes 1 e 3 o concentrado de $\lg G$ foi preparado usando processo parcial e nos lotes 4,5 e 6 o processo foi completo. Para o calculo das atividades de $\mathrm{FXI}$ nas preparações de $\lg \mathrm{G}$, a curva padrão foi feita com diluições de plasma de $12,5 \%$ até $0,049 \%$ e resultou na equação:

$$
\text { Logt }=-0,09 \log (\% \mathrm{PI})+1,7698 \quad\left(R^{2}=0,9599\right) .
$$

Os cálculos são apresentados na tabela IV.

Tabela IV - Dosagem de FXI, lotes de preparação de IgG no laboratório piloto.

\begin{tabular}{ccccc}
\hline Amostras & Tempo (s) & Log T & Log (\%pls) & $\%$ Ativ \\
\hline IgG Lote 1 & 70,20 & 1,84 & $-0,85$ & 0,14 \\
\hline IgG Lote 3 & 70,25 & 1,84 & $-0,85$ & 0,14 \\
\hline IgG Lote 4 & 63,50 & 1,80 & $-0,36$ & 0,43 \\
\hline IgG Lote 5 & 62,85 & 1,79 & $-0,31$ & 0,48 \\
\hline IgG Lote 6 & 65,70 & 1,81 & $-0,53$ & 0,29 \\
\hline
\end{tabular}

As dosagens de $\mathrm{FXI}$ nas preparações de IgG referem-se à \% de atividade em relação àquela encontrada no plasma normal. Verifica-se que os valores são semelhantes ao encontrado em uma série de amostras comerciais, reportados na literatura (0,68 a <0,01\% plasma) (WOLBERG; KON; MONROE, 2000). Interessante notar que as preparações por processo completo (4, 5 e 6) apresentam maior atividade que as preparações usando processo parcial. $O$ aumento de atividade de FXI em amostras que passaram por separação de proteínas dependentes de vitamina $\mathrm{K}$ por cromatografia de troca aniônica já havia sido comentado por um pesquisador especialista em produção de hemoderivados (comunicação pessoal). Ainda deve-se considerar que existe uma distinção na literatura sobre o risco de atividade pro-coagulante segundo a presença de FXI ou FXla nas preparações (WOLBERG; KON; MONROE, 2000).

São necessárias mais avaliações sobre atividade de FXI nas preparações de $\lg G$ e os ensaios deverão ser reproduzidos, também por método cromogênico, incluindo amostras comerciais de $\lg G$. 


\section{5 - Cromatografia Direta de plasma em Q. Sepharose}

Uma proposta do laboratório é a utilização de cromatografia direta de plasma em resina de Q-Sepharose (CHENG et al., 2010). Nessa cromatografia as proteínas majoritárias do plasma, albumina e lgG, são eluidas no "flow through" (F1-Q), enquanto as proteínas dependentes de vitamina $\mathrm{K}$ são eluĺdas com concentração maior de sal, na fração F3-Q. Estudamos a separação de FXI nesse processo em cromatografias realizadas em $\mathrm{pH} 6$ ou $\mathrm{pH} 7$.

O plasma coletado com anticoagulante (na bolsa) apresenta $\mathrm{pH}$ em torno de $7,4, \mathrm{pH}$ usualmente utilizado no inicio de fracionamento do plasma nos processos industriais.

Nos ensaios descritos de cromatografia direta em resina Q-Separose, o $\mathrm{pH}$ do plasma era baixado para 6,0 com acido cítrico, para estabilizar a proteína de interesse, Fator VIII de coagulação (3.3.2). Decidimos estudar as duas condições de pH para avaliar o efeito na adsorção/eluição de FXI. Nesses ensaios não foi utilizada heparina.

A Figura 21 mostra os cromatogramas do fracionamento de plasma em resina Q-Sepharose utilizando $\mathrm{pH} 6$ ou 7, sendo os tampões equilíbrio feitos com pH 6 ou 6,4 respectivamente. 
A

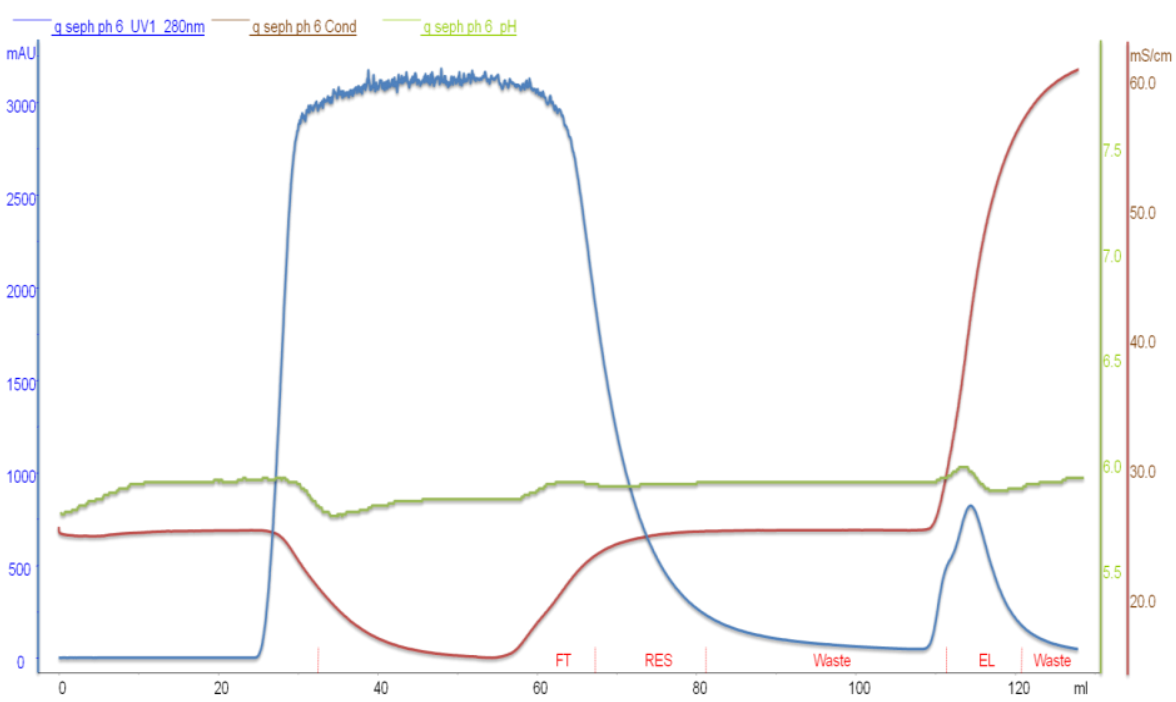

B

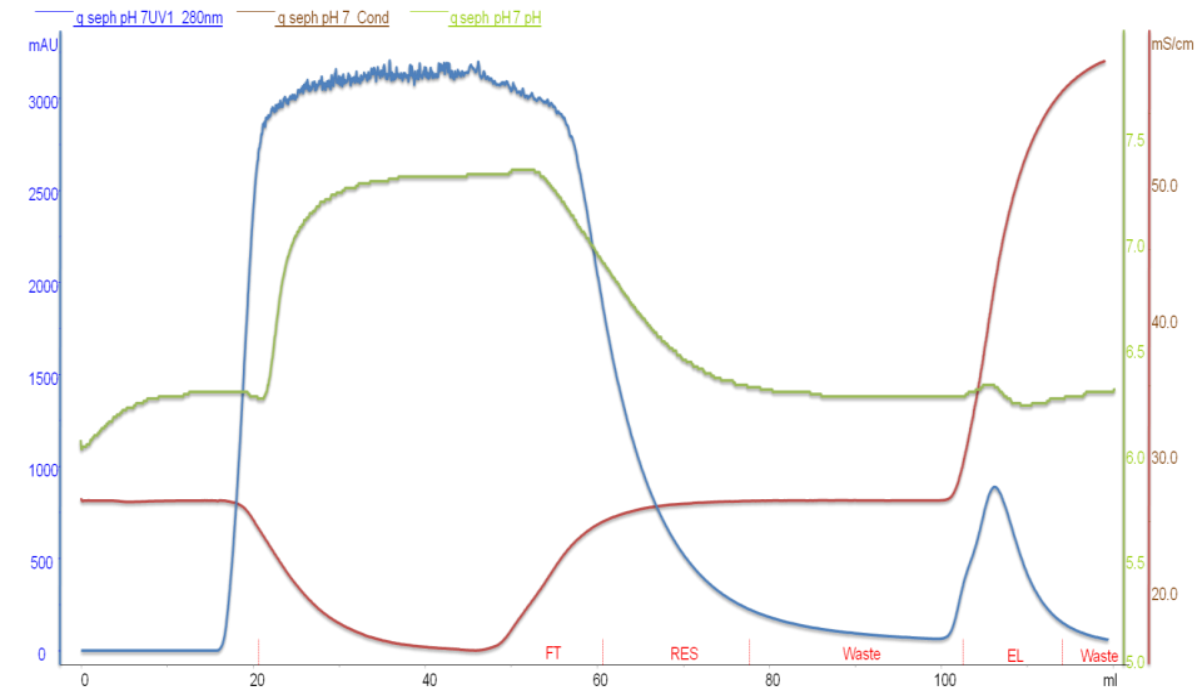

Figura 21 - Cromatogramas da separação de plasma em resina Q Sepharose. Na primeira cromatografia (A) o plasma foi ajustado para $\mathrm{pH} \mathrm{6,0} \mathrm{com} \mathrm{citrato} \mathrm{e} \mathrm{na} \mathrm{segunda}$ (B) o plasma foi utilizado no $\mathrm{pH}$ original, 7,4. Na primeira cromatografia (A) foram aplicados $25 \mathrm{~mL}$ de plasma à coluna Q-Sepharose de $5 \mathrm{~mL}$, sendo recolhido o "flow through" (FT) em $35 \mathrm{~mL}$. Uma fração residual do "flow through" (RES) foi coletada em $14 \mathrm{~mL}$ e a fração eluída com maior concentração de sal (500 mM de $\mathrm{NaCl}$ ) (EL) foi coletada em $10 \mathrm{~mL}$. Na segunda cromatografia (B) $25 \mathrm{~mL}$ de plasma em pH 7,4 foram aplicados à coluna, sendo coletado FT em $40 \mathrm{~mL}$, RES em $17 \mathrm{~mL}$ e a fração EL em $12 \mathrm{~mL}$. 
4.5.1 Dosagem de atividade de FXI em amostras de Q. Sepharose por tempo de coagulação, em placas de ELISA

Para a dosagem de atividade de FXI por tempo de coagulação, foram feitas duas curvas padrão utilizando diluições do plasma em pH 6,0 e diluições do plasma em $\mathrm{pH}$ 7,4 . As equações determinadas estão abaixo.

$$
\begin{array}{ll}
\log T=-0,1271 \log (\% \text { plasma })+1,8162 & \text { para } \mathrm{pH} 6,0 \\
\log T=-0,131 \log (\% \text { plasma })+1,7957 & \text { para } \mathrm{pH} 7,0
\end{array}
$$

Os tempos de coagulação das amostras das frações cromatográficas estão apresentados na Tabela $\mathrm{V}$, bem como os cálculos de atividade.

Tabela V - Atividade de FXI em frações cromatográficas de plasma em Q. Sepharose usando o plasma em $\mathrm{pH} 6 \mathrm{e} \mathrm{pH} 7$.

\begin{tabular}{ccccccccc}
\hline Amostra & $\begin{array}{c}\text { Tempo } \\
\text { (s) }\end{array}$ & $\begin{array}{c}\text { Log } \\
\text { tempo }\end{array}$ & $\begin{array}{c}\text { Log } \\
\text { \%pl }\end{array}$ & $\begin{array}{c}\text { \% at } \\
\text { amostra }\end{array}$ & $\begin{array}{c}\text { Vol } \\
\text { fração }\end{array}$ & $\begin{array}{c}\text { Ativ } \\
\text { Fração }\end{array}$ & $\begin{array}{c}\text { \% ativ } \\
\text { fração }\end{array}$ \\
\hline \multirow{3}{*}{$\mathrm{pH} 6$} & Plasma & 34,8 & 1,54 & 2,0 & 87,1 & 25 & 2176,8 & 100,0 \\
\cline { 2 - 9 } & $\mathrm{FT}$ & 32,0 & 1,5 & 2,2 & 165,2 & 34,7 & 5731,5 & 263,3 \\
\cline { 2 - 9 } & $\mathrm{RES}$ & 52,0 & 1,71 & 0,6 & 4,1 & 13,9 & 56,4 & 2,6 \\
\cline { 2 - 9 } & $\mathrm{EL}$ & 57,3 & 1,75 & 0,3 & 1,9 & 9,5 & 18,4 & 0,8 \\
\hline \multirow{3}{*}{$\mathrm{pH7}$} & Plasma & 37,2 & 1,57 & 1,9 & 85,7 & 25 & 2142,0 & 100,0 \\
\cline { 2 - 9 } & $\mathrm{FT}$ & 36,3 & 1,55 & 2,0 & 103,9 & 39,9 & 4144,2 & 193,5 \\
\cline { 2 - 9 } & $\mathrm{RES}$ & 58,5 & 1,76 & 0,4 & 2,4 & 17 & 41,3 & 1,9 \\
\cline { 2 - 8 } & $\mathrm{EL}$ & 63,2 & 1,8 & 0,1 & 1,3 & 11,5 & 15,2 & 0,7 \\
\hline
\end{tabular}

As atividades de FXI calculadas nas frações estão ilustradas no gráfico da Figura 22.

Observa-se que a atividade de FXI foi recuperada integralmente no "flow through" tanto na cromatografia em $\mathrm{pH} 6$ como em $\mathrm{pH}$ 7,4.

Observa-se tambem que maior atividade é recuperado do que a calculada no plasma de entrada. Possivelmente um agente inibidor de FXI está sendo removido na cromatografia.

$O$ resultado pode ser comparado com a cromatografia em DEAE, na qual o FXI também foi separado no "flow through". 


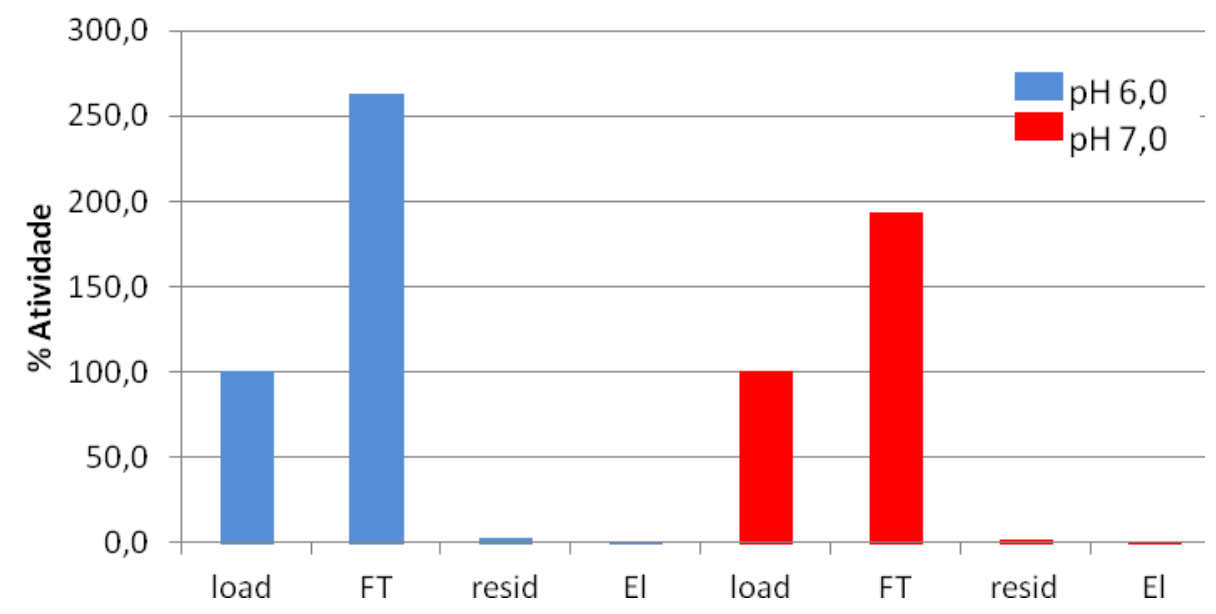

Figura 22 - Atividade de FXI dosada por tempo de coagulação (aPTT) em amostras das frações cromatográficas de e plasma em resina Q.Sepharose. Cromatografias realizadas com plasma em $\mathrm{pH} 6$ e $\mathrm{pH} 7$.

Estabelecemos o ensaio de dosagem de FXI também pelo método cromogênico, usando hidrólise do peptídeo cromogênico S2366. O peptídeo é ligado a p-nitroanilina e quando hidrolisado gera cor que pode ser lida em $405 \mathrm{~nm}$.

\subsubsection{Dosagem de atividade de FXI por hidrólise de peptídeo cromogênico}

O FXI ativado pode ser medido por ensaio amidolítico, por hidrolise de substrato cromogênico S2366. A atividade de FXla pode ser acompanhada por aumento de absorbância $405 \mathrm{~nm}$ gerando curvas cinéticas de variação de absorbância por tempo $(\Delta \mathrm{Abs} / \Delta \mathrm{T})$. Espera-se uma curva de linear de variação de $\Delta \mathrm{Abs} / \Delta \mathrm{T}$ com variação da concentração de FXla.

Entretanto, o plasma possui inibidores de FXla, possivelmente como reguladores do processo de coagulação, que interferem com as dosagens. Foi descrito que os inibidores podem ser removidos por tratamento do plasma com clorofórmio, sem afetar a quantidade ou ativação do FXI (SCOTT et al., 1984). De fato, não foi possível dosar FXI em plasma não tratado por clorofórmio (dados não mostrados). Portanto, em todos os ensaios descritos, o plasma e amostras foram tratados por clorofórmio.

Além dos inibidores plasmáticos, outras interferências devem ser consideradas na dosagem de FXI. Outras enzimas também são capazes de 
hidrolisar o mesmo substrato, incluindo Calicreína e Fator Xlla, que tem estreita relação com a ativação do FXI. Por isso, em certos pontos do ensaio são incluídos os inibidores STI e CTI para eliminar as atividades de Calicreína e FXIla respectivamente.

Para dosagem de FXI por ensaio amidolítico nas frações da cromatografia de plasma em resina $Q$-sepharose, inicialmente foram estabelecidas as curvas cinéticas com diferentes diluições de plasma (Figura 23).

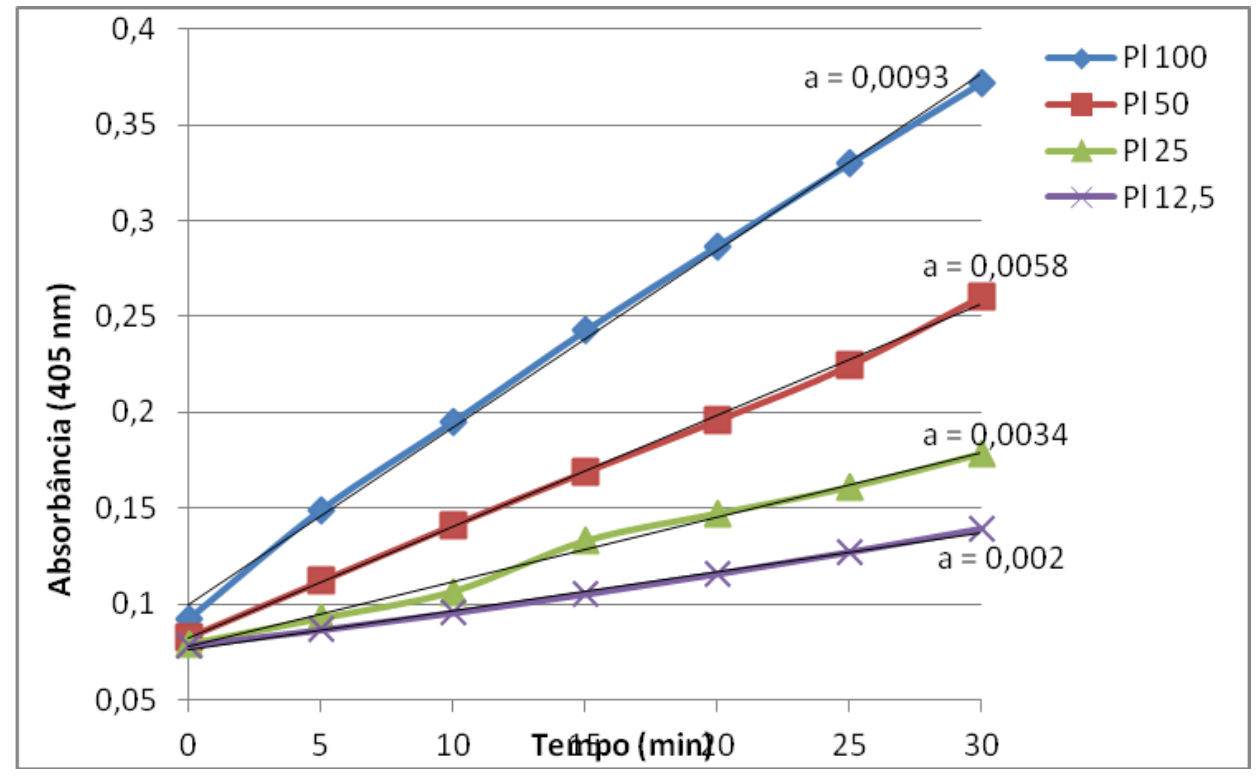

Figura 23 - Dosagem de FXI por método cromogênico. Cinética da hidrólise de peptídeo cromogênico S2366 em plasma deficiente em FXI com amostras de diferentes diluições de plasma normal como indicado na figura. As reações em placa de ELISA foram iniciadas simultaneamente por adição de ativador Actin. As leituras de absorbância $405 \mathrm{~nm}$ foram feitas automaticamente a cada 5 minutos. O coeficiente angular das curvas $(\Delta \mathrm{Abs} / \Delta \mathrm{t})$ mostrados na figura foi calculado usando o programa Exell. .

Os valores de coeficiente angular de cada diluição em função das diluições determinaram uma equação linear, como ilustrado na Figura 24. 


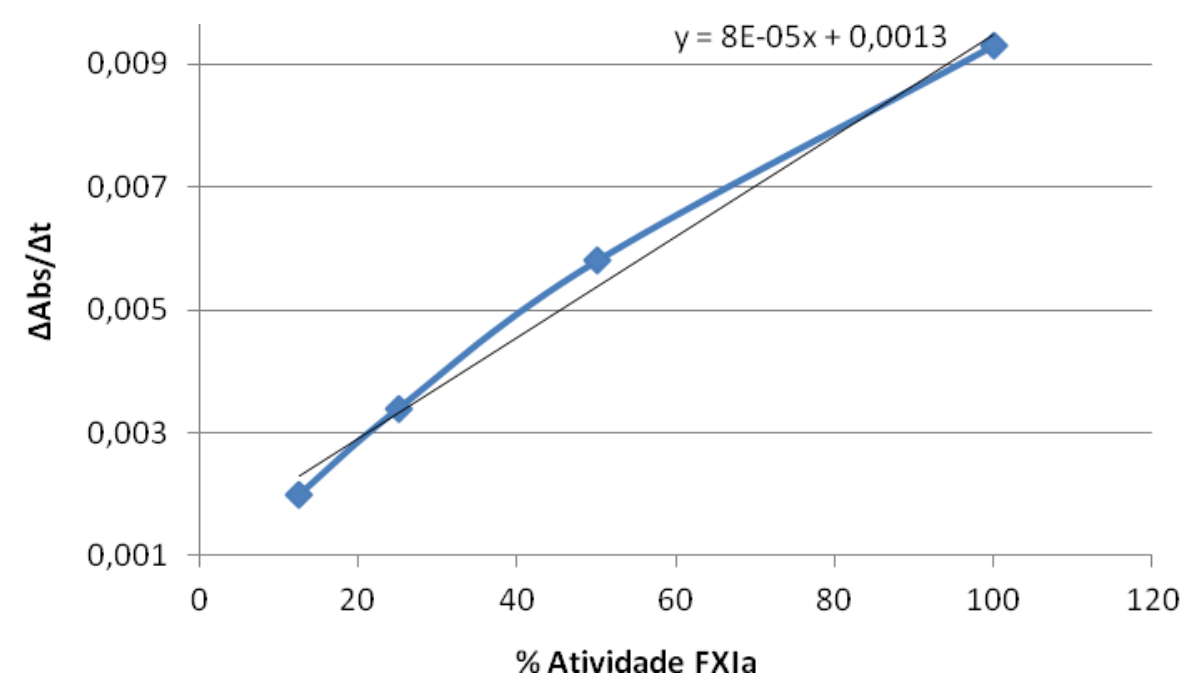

Figura 24 - Curva padrão estabelecida com os coeficientes angulares das curvas de cinética $\Delta \mathrm{Abs} / \Delta \mathrm{t}$ em função da porcentagem de plasma e portanto, da atividade de FXI nas diluições do plasma.

A atividade $\mathrm{FXI}$ nas frações cromatográficas foi dosada pelo método amidolítico. As curvas cinéticas na Figura 25 ilustram o ensaio.

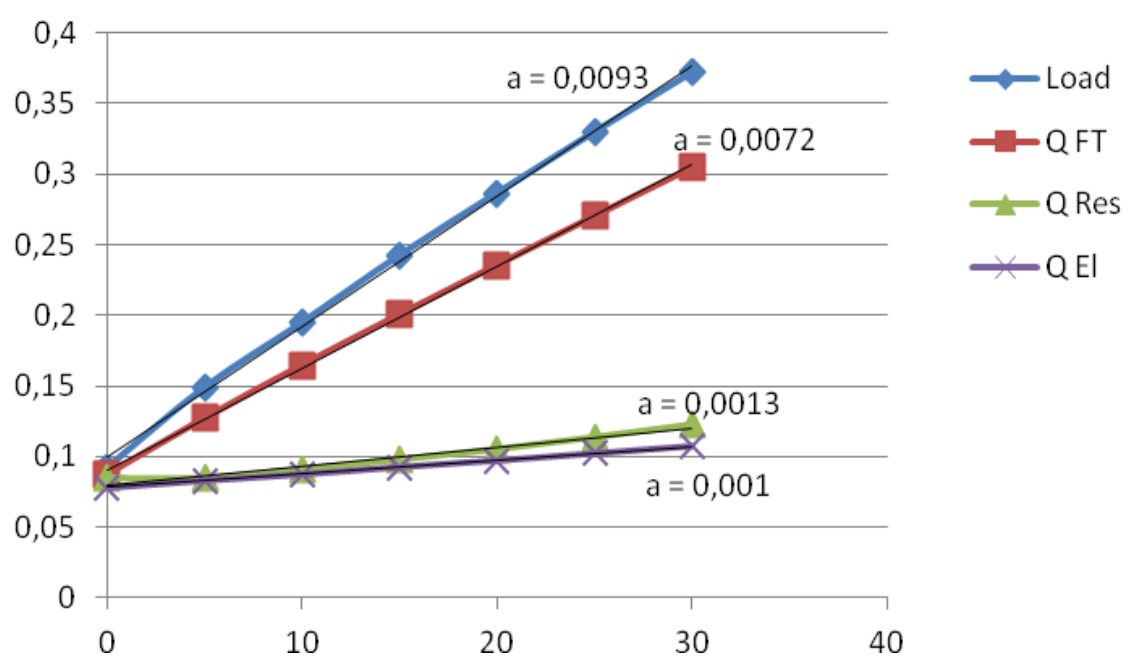

Figura 25 - Dosagem de FXI por método cromogênico em frações da cromatografia de plasma em resina Q-Sepharose. O plasma deficiente em FXI foi adicionado das amostras indicadas. Load (plasma); Q-FT - "flow through"; RES - inicio da lavagem da coluna; Q-EL - eluição. Ara reações foram iniciadas simultaneamente por adição de actin. As leituras de absorbância $405 \mathrm{~nm}$ foram feitas automaticamente a cada 5 minutos iniciando logo após adição das amostras ao substrato cromogenico. Os coeficientes angulares das curvas de cada amostra $(\Delta \mathrm{Abs} / \Delta \mathrm{t})$ foram calculados pelo programa excel e estão indicados no gráfico. 
Os valores de coeficiente angular da cinética de cada amostra foram inseridos na equação

$$
\Delta \mathrm{Abs} / \Delta \mathrm{t}=0,00005[\text { plasma] }+0,0013
$$

determinada na curva padrão obtida com as diluições de plasma (Figura 24). Os valores de coeficiente angular $(\Delta \mathrm{Abs} / \Delta \mathrm{t})$ para cada amostra, cálculo de atividade na amostra em teste (relativo à \% de atividade no plasma), e cálculo de atividade total em cada fração e a porcentagem de atividade recuperada em cada fração estão apresentados na Tabela VI.

Tabela VI - Cálculo da atividade de FXI em amostras da cromatografia de plasma em Q. Sepharose.

\begin{tabular}{cccccc}
\hline Amostra & $\begin{array}{c}\text { Coef. angular } \\
\mathbf{\Delta A b s / \Delta t}\end{array}$ & $\begin{array}{c}\text { \% atividade* } \\
\text { amostra }\end{array}$ & $\begin{array}{c}\text { Volume } \\
\text { fração }\end{array}$ & $\begin{array}{c}\text { Atividade } \\
\text { fração }\end{array}$ & $\begin{array}{c}\text { \% de } \\
\text { atividade }\end{array}$ \\
\hline Load & 0,0093 & 100 & 25 & 2500 & 100 \\
\hline Q. FT & 0,0072 & 73,75 & 34,7 & 2559 & 102,4 \\
\hline Q. Res & 0,0013 & 0 & 13,9 & 0 & 0 \\
\hline Q. El & 0,001 & $-3,25$ & 9,5 & - & - \\
\hline
\end{tabular}

Os dados mostram que a totalidade da FXI aplicado na coluna Q-Sepharose é recuperada na fração de "flow through", como verificado pelo ensaio cromogênico. $O$ resultado mostra também que as proteínas de coagulação FVIII e as dependentes de vitamina $K$ que são recuperadas na fração de eluição não interferem no ensaio de dosagem de FXI.

Alguns ensaios foram realizados para testar a interferência de FXII e calicreína na dosagem de FXI: adicionamos o inibidor de calicreína (STI) após a ativação de FXII com cefalina/ac. elágico (o inibidor é normalmente introduzido antes da ativação de FXII), para testar a atividade de calicreína durante a ativação do FXII . A calicreína interfere positivamente na ativação de FXI por FXIla e também hidrolisa o substrato cromogênico. Em outro ensaio não adicionamos o inibidor CTI para verificar a intensidade da ação de FXlla sobre o substrato. A Figura 26 ilustra o ensaio com variação dos inibidores. 


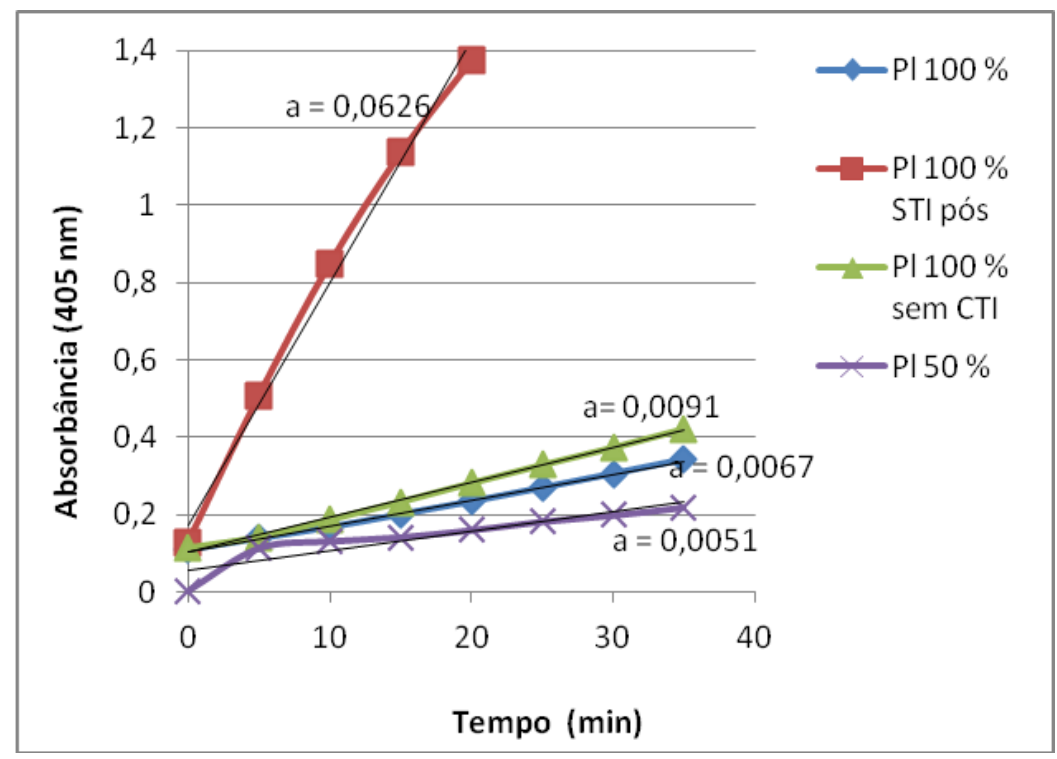

Figura 26 - Dosagem de FXI por método cromogênico. Plasma deficiente em FXI adicionado de amostras de plasma normal foram tratadas com clorofórmio, ativadas por cefalina/ac. elágico (Actin) e adicionadas ao substrato cromogênico para acompanhar as cinéticas de hidrólise. As amostras foram: PI 100\% - plasma sem diluição; PI 100\% STI pós - STI foi adicionado após a ativação por cefalina; PI 100\% sem CTI - não foi adicionado o inibidor CTI ao final da ativação; PI 50\% - plasma diluído 1:2. Após ativação com actin as amostras foram adicionadas ao substrato cromogênicos e as leituras de absorbância $405 \mathrm{~nm}$ iniciadas automaticamente, sendo feitas a cada 5 minutos, com agitações intermediárias. Os coeficientes angulares das curvas $(\Delta \mathrm{Abs} / \Delta \mathrm{t})$ estão indicados para cada amostra.

O ensaio mostrou que ocorre grande interferência na hidrólise do substrato se a calicreína não é inibida antes da ativação do Fator XII por Actin. O Fator XII também ativa a calicreína. Não pudemos precisar se o inibidor STI impede a ativação da calicreína ou se inibe a calicreína no início da ativação, mas ela não pode ser bloqueada se o STI é introduzido após a ativação. O ensaio confirma que o inibidor deve estar presente no momento da ativação como descrito por Scott et al. (1984).

A ausência do inibidor do Fator XII elevou em cerca de $30 \%$ a reação amidolítica.

4.5.3 Avaliação da presença de FXI em frações da cromatografia de plasma em resina Q-Sepharose por western blot.

As dosagens de atividade de FXI por ensaio amidolítico confirmaram que o fator estava sendo recuperado integralmente no "flow through" da cromatografia de 
plasma em resina Q-Sepharose. Decidimos avaliar o reconhecimento do FXI nessa fração por western blot.

O ensaio de western blot com frações plasmáticas é limitado pela alta massa de proteínas nas amostras, o que interfere na eletroforese. Somente pequenos volumes de amostra podem ser aplicados (exemplo: usamos $\sim 1 \mu \mathrm{L}$ de plasma). Para melhorar a condição do western blot, e melhorar o controle do ensaio por deteç̧ão de FXI em amostras controle, utilizamos duas estratégias para remover as proteínas majoritárias:

- A resina Star Hypercell (Pall), descrita como específica para captura de albumina foi usada para diminuir a concentração da proteína em amostras de plasma, permitindo a aplicação de maior volume de amostra e assim ultrapassar o limite de detecção do FXI. Assim, amostra de plasma foi aplicada para cromatografia em resina Star Hypercell e o "flow through", com menor quantidade de albumina, foi usado no western blot;

- Uma resina ainda em desenvolvimento para captura de lgG, aqui chamada de Nova Resina (NR), foi utilizada para remover IgG. Uma amostra de plasma pobre em albumina ("flow through" da Star Hypercell) foi aplicada para cromatografia na NR.

As amostras utilizadas no ensaio de western blot da Figura 27 foram: Fração "flow through" do plasma na da resina Star, (Star-FT); Frações de "Flow through" (NR-FT) e de eluição (NR-EL) de Star-FT aplicada na nova resina; Frações de "Flow through" e de eluição (Q-FT) de plasma em resina Q-Sepharose (Q-FT). 

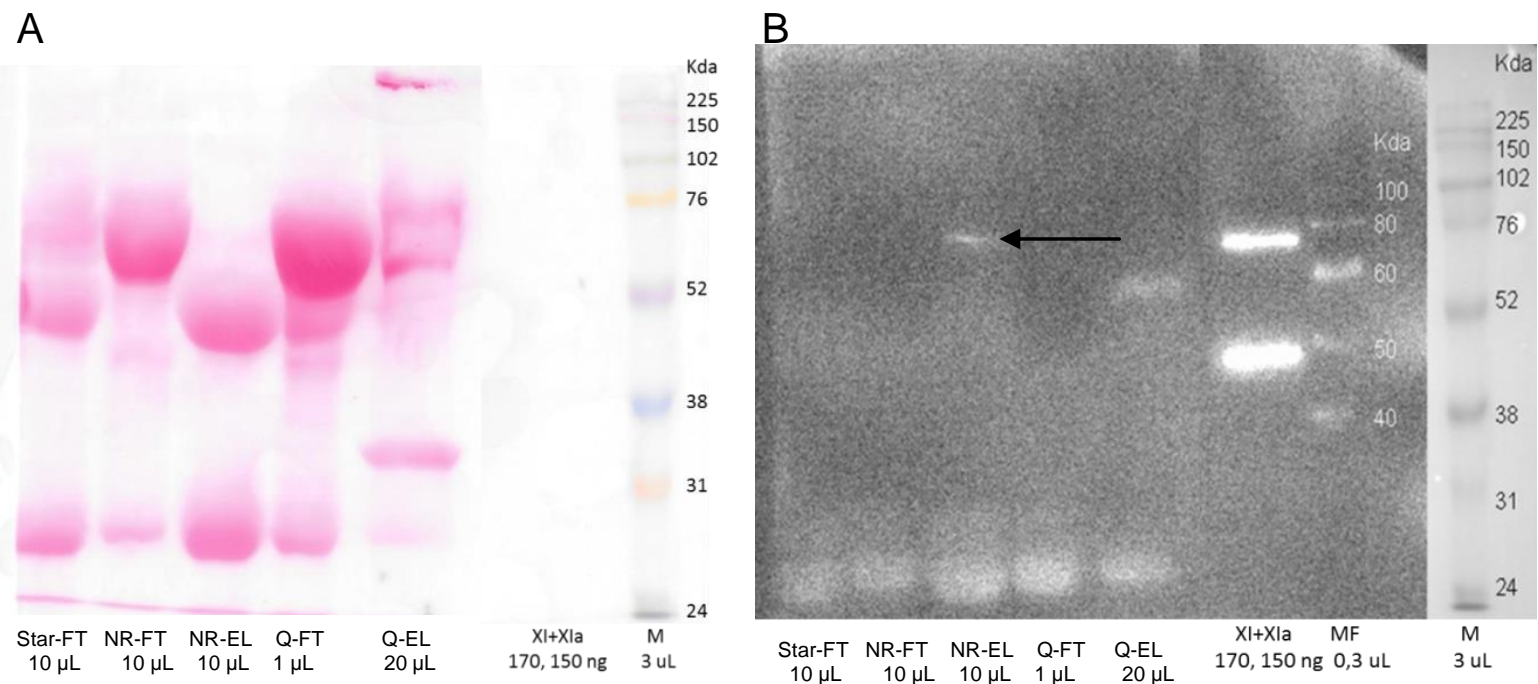

Figura 27. Detecção de FXI em amostras de frações de cromatografia de plasma, por western blot. À esquerda $(\mathbf{A})$ a membrana corada por Ponceau e à direita $(\mathbf{B}) \mathrm{a}$ detecção por anticorpos anti-FXI revelada por ECL. Os volumes das amostras aplicados estão indicados na figura. A concentração das amostras relativa ao volume de plasma está indicada entre parênteses. Amostras Star FT (diminuídas em albumina) (diluído 1,5x); NR-FT "Flow through" da nova resina (diluído 1,5x); NR-EL - eluição da nova resina (concentrado 1,5x); Q-FT (1X), Q-EL (concentrado 1,2x); MF - marcador florescente $(0,3 \mu \mathrm{l})$; e $\mathrm{M}$ - marcador $(3 \mu \mathrm{l})$. Amostras de FXI e FXla comerciais foram usadas como controle.

No western blot verificamos que não foi possível detectar a banda de FXI na amostra de plasma, mesmo tendo aumentado o volume aplicado no gel após depletar a amostra de albumina.

Uma banda foi detectada na posição de FXI (80 kDa) na fração de lgG eluída da nova resina (NR-EL). Interessante que essa resina foi desenhada para captura específica de IgG e possivelmente esteja capturando FXI. Esse evento sugere que essas proteínas têm características semelhantes que fazem com que se separem na mesma fração, o que reforça a necessidade do cuidado especial em verificar a ausência de contaminação de FXI em preparações de lgG.

Uma banda foi determinada na fração de eluição da cromatografia de plasma em resina Q-Sepharose (Q-EL), em posição semelhante àquela banda que verificamos na fração de eluição da DEAE-Sepharose (Figura 17D). As bandas de reconhecimento do $\mathrm{FXI}$ e da cadeia pesada do FXla são nítidas e permitem verificar que a banda na fração Q-EL está na posição em torno de $60 \mathrm{kDa}$. O Fator XI tem identidade com outras proteínas do plasma, inclusive tem $68 \%$ de identidade com um dos domínios de calicreína. Mais investigações em torno da proteína que poderia estar sendo reconhecida pelo anticorpo anti-FXI são necessárias. 


\section{DISCUSSÃO}

A relação entre eventos tromboembólicos (TEEs) em pacientes que receberam infusões de IgIV com contaminações de FXI nos concentrados de Imunoglobulinas foi confirmada (JOSÉ et al., 2013). O principal método utilizado para verificar a contaminação de FXI nas preparações comerciais de IgIV foi o aPTT (WOLBERG; KON; MONROE, 2000).

Temos trabalhado com purificação de proteínas de plasma, sendo um dos objetivos a purificação de imunoglobulinas. Dois métodos principais estão em estudo:

- O processo destinado à planta Industrial do Butantan, Processo Cromatográfico, o qual é iniciado por uma etapa de gel filtração. Esse processo foi realizado em escala piloto e algumas etapas foram realizadas em escala de bancada;

- Uma variante do processo estudada no laboratório é a cromatografia direta de plasma em resinas Q-Sepharose, o que substituiria a etapa inicial do processo industrial, a gel filtração, permitindo a cromatografia mais rápida ( $1 / 5$ de tempo e menores volumes de soluções).

Neste trabalho mostramos etapas de purificação de $\lg G$ pelos dois processos em estudo, em escala piloto e em escala de bancada. Nosso objetivo era verificar se havia FXI no produto IgG obtido pelo Processo Cromatográfico em Escala Piloto e também rastrear o FXI nas etapas iniciais do processamento.

O método aPTT foi usado para rastrear a separação de FXI nas frações cromatográficas. Estabelecemos também o método cromogênico de dosagem e ainda ensaios de western blot usando anticorpo monoclonal anti-FXI.

Através do ensaio de coagulação, verificamos que somente pequena proporção da atividade de FXI ( 20\%) foi encontrada na fração F3-4FF da primeira etapa de cromatografia em gel filtração. Entretanto, a atividade do fator foi recuperada ( $80 \%)$ na fração F1-DEAE da segunda cromatografia. O que ocorre é que o plasma em seu preparo, é adicionado de heparina e esta, além aumentar a 
atividade da antitrombina III em 1000 vezes inibindo a coagulação (Figura 18), pode também inibir diretamente o FXI (ZHAO; ABDEL-RAZEK; SUN,1998). A recuperação de atividade de FXI na fração F1-DEAE ("flow through") está possivelmente relacionada com adsorção da heparina na resina DEAE-Sepharose. De fato, existem métodos de purificação de heparina (uma molécula bastante carregada negativamente) usando cromatografia em resinas de troca aniônica descritos na literatura (SANTOS et al., 2014). Ou seja, em nossos ensaios a heparina pode ter sido adsorvida à resina DEAE Sepharose, ligada ou não a AT-III, possibilitando a dosagem de $\mathrm{FXI}$ nas frações eluídas da coluna.

A atividade de FXI também foi recuperada, no processo de cromatografia direta de plasma em Q. Sepharose, na fração de "flow through", Q-FT, confirmando que nas condições de ensaio o FXI não se liga às resinas de troca aniônica.

Os resultados de eluição de FXI no "flow through" da cromatografia de plasma em Q. Sepharose foi confirmado por ensaio pelo método cromogênico.

Dosagens de FXI em concentrado de IgG obtido na planta piloto indicaram a presença do fator em concentração relativamente alta, na ordem de grandeza encontrada em amostras comerciais referidas como contaminadas.

Comparando-se os métodos de coagulação e cromogênico utilizados para dosagem de atividade do FXI, listamos uma série de prós e contras:

Apesar de ambos os métodos utilizarem cefalina em ácido elágico como ativador de FXII, o método cromogênico utiliza os inibidores CTI e STI que são reagentes caros.

O método cromogênico pode ser considerado mais especifico, já que no tratamento da amostra diferentes inibidores de FXI são eliminados. $O$ ensaio também adiciona inibidores de outras enzimas proteoliticas,e assim restringe a ação sobre o substrato somente a atividade de FXI.

O substrato cromogênico usado pode ser hidrolisado por outras enzimas da cascata de coagulação como o FXIla e calicreina, o que deve ser controlado com o uso de inibidores. Outros substratos também são propostos para dosagem de FXI, porém, para medidas indiretas através de hidrólise por FXa, sendo assim passível de mais interferentes.

O método cromogênico é mais demorado e inclui mais passos de processo em comparação com o método de coagulação, o qual é feito diretamente, sem tratamento de amostras. 
Os dois métodos sofrem interferência por heparina, uma vez que a heparina pode também ligar-se diretamente ao $\mathrm{FXI}$, possivelmente com afinidade menor do que se liga à AT-III (ZHAO; ABDEL-RAZEK; SUN,1998).

Uma desvantagem do método de coagulação é que pode sofrer interferências se eventualmente outros fatores ativados estiverem presentes nas amostras, como FIXa ou FXa (ROEMISCH et al, 2012).

É Importante notar que os dois métodos exigem alta precisão nas manipulações, já que são sensíveis a segundos de diferença nas reações de ativação.

Os ensaios por western blot demonstram bandas nítidas com peso molecular em torno de $60 \mathrm{KDa}$ nas amostras de eluição da coluna DEAE Sepharose (F3$D E A E)$ e da coluna $Q$ Sepharose ( $Q-E L)$. Essa banda proteica não confirma a presença do $\mathrm{FXI}$, que seria de 80 ou $50 \mathrm{KDa}$.

Usando ensaios de western blot, não foi possível detectar FXI ou FXla nas amostras de "flow through" dos processos de purificação descritos, uma vez que são muito concentradas em albumina e lgG e volumes limitados podem ser aplicados ao ensaio.

O FXI foi detectado apenas em amostra de eluição (concentrada) da Resina Nova, com banda em torno de $80 \mathrm{KDa}$. Usando essa resina, a fração de eluição é concentrada em lgG. O FXI foi também concentrado nessa fração, sendo possível, pela primeira vez detectarmos o fator plasmático (figura 27). A eluição do FXI juntamente com IgG na coluna que teoricamente seria específica para imunoglobulina mostra que as duas proteínas tem similaridades, o que requer estudo especial para garantir a separação. 


\section{CONCLUSÃO}

Os resultados mostram que mesmo em diferentes métodos de purificação, o FXI acompanha a $\operatorname{lgG}$ nas etapas iniciais nas trocas aniônicas, com atividade recuperada nas frações de "flow through", como demonstrado pelos métodos de coagulação e cromogênico. Também usando a Nova Resina desenhada para purificação específica de IgG, verificamos por western blot que o $\mathrm{FXI}$ acompanha a imunoglobulina, é possível notar a banda de FXI na fração de eluição da Nova Resina. Também foi verificada a atividade FXla por coagulação nos lotes IgG piloto, com resultados na ordem de grandeza de IgGs comerciais.

Assim, o trabalho apresentado contribui no sentido de estabelecer métodos para o controle de qualidade de concentrados de imunoglobulinas quando a planta industrial de fracionamento de plasma for habilitada.

A produção de hemoderivados é bastante complexa, especialmente frente à grande preocupação com efeitos adversos e com infecções virais. As inovações nessa área são amplas e os protocolos de controle de qualidade são cada vez mais específicos.

O trabalho ora apresentado marca o aspecto de que o grupo de pesquisa se insere no contexto de que, além dos controles impostos pelas agências regulatórias, é necessária a contínua investigação de contaminantes, processos e interferentes que possam vir a apresentar risco no produto. 


\section{PERSPECTIVAS}

Os métodos de dosagem de FXI estabelecidos se complementam e permitiram rastrear a proteína nas frações cromatográficas. Nossa perspectiva é aplicar essas metodologias na identificação do FXI nas frações do processo cromatográfico completo, de forma a avaliar as etapas em que a separação do FXI e IgG possam ser melhoradas para garantia do produto final.

Essas metodologias se inserem no desenvolvimento do programa de controle de qualidade dos produtos hemoderivados. 


\section{REFERÊNCIAS*}

BARANDUN, S.; IMBACH, P.; KINDT, $\mathrm{H}$. et al. Clinical Applications of Immunoglobulin (Gamma Globulin): a review of current findings. Basle, Switzerland: Sandoz Products Ltd., 1982. 87 p.

BARNA, G. A. O. Estudo comparativo "in vitro" entre preparações de imunoglobulina G, para uso intravenoso, obtidas de plasma humano de variadas procedências e processadas por diferentes técnicas de separação. 117 f. Dissertação (Doutorado em Fármaco e Medicamentos) - Universidade de São Paulo, São Paulo, 2001.

BORDIN, J. O.; JÚNIOR, D. M. L.; COVAS. D. T. Hemoterapia: fundamentos e prática. 1.ed. São Paulo: Atheneu, 2007. 632 p.

BURNOUF, T. Modern plasma fractionation. Transfusion Medicine Reviews, v. 21, n. 2, p. 101-117, 2007.

CHENG, E., JINZENJI, D., LORTHIOIS, A., DE CARVALHO, R.R. et al. Purification of coagulation factor VIII using chromatographic methods. Direct chromatography of plasma in anion exchange resins. Biotechnology Letters, v. 32, p. 1207-1214, 2010.

COHN, E. J.; ONCLEY, J. L.; STRONG, L. E.; HUGHES, W. L.; ARMSTRONG, S. H. Chemical, Clinical, and Immunological Studies on the products of Human Plasma Fractionation. I. The characterization of the Protein fractions of Human Plasma. Journal of Clinical Investigation, v. 23, p. 417-432, 1944.

CROSBY, J. R.; MARZEC, U.; REVENKO, A. S. et al. Antithrombotic Effect of Antisense Factor XI Oligonucleotide Treatment in Primates. Arteriosclerosis, Thrombosis, and Vascular Biology, v. 33, p. 1670-1678, 2013.

*De acordo com: ASSOCIAÇÃO brasileira de normas técnicas. NBR 6023: Informação e documentação: referências: elaboração. Rio de Janeiro, 2002. 
EMSLEY, J.; MCEWAN, P. A.; GAILANI, D. Structure and function of factor XI. Blood, v. 115, n. 13, p. 2569-2577, 2010.

ETSCHEID, M.; BREITNER-RUDDOCK, S.; GROSS, S.; HUNFELD, A.; SEITZ, R.; DODT, J. Identification of kallikrein and FXla as impurities in therapeutic immunoglobulins: implications for the safety and control of intravenous blood products. Vox Sanguinis, v. 102, p. 40-46, 2012.

FARRUGIA, A. et al. Plasma fractionation issues. Biologicals, v.37, p. 88-93, 2009.

GAILANI, D.; SMITH, S. B. Structural and functional features of factor XI. Journal of Thrombosis and Haemostasis, v. 7, p. 75-78, 2009.

JOSÉ, M.; MARZO, N.; PONS, B. et al. Flebogamma® DIF (intravenous immunoglobulin) purification process effectively eliminates procoagulant activities. Biologicals (2013). Disponível em: <http://dx.doi.org/10.1016/i.biologicals.2013.08.002 >

KAERSGAARD, P.; BARINGTON, K. A. Isolation of the factor VIII-von Willebrand factor complex directly from plasma by gel filtration. Journal of Chromatography, v. 715, p. 357-367, 1998.

LAEMMLI, U. K. Cleavage of structural proteins during assembly of the head of bacteriophage T4, Nature, v. 227, p. 680-685, 1970.

NILSSON, I. M.; BERNTORP, E.; LETHAGEN, S. et al. Hemophilia. Stockholm, Sweden: Pharmacia plasma products, 1994. 100 p.

PILLEMER, L.; ECKER, E. E.; ONCLEY, J. L.; COHN, E. J.. The preparation and physicochemical characterization of the serum protein components of complement. Journal of Experimental Medicine, v. 74, p. 297-308, 1941. 
PONCZEK, M. B.; GAILANI, D.; DOOLITTLE, R. F. Evolution of the contact phase of vertebrate blood coagulation. Journal of Thrombosis and Haemostasis, v. 6, p. 1876-1883, 2008.

RADOSEVICH. M.; BURNOUF. T. Intravenous immunoglobulin G: trends in production methods, quality control and quality assurance. Journal compilation. International Society of Blood Transfusion, Vox Sanguinis, v. 98. p.12-28, 2009.

ROEMISCH, J. R.; KAAR, W.; ZOECHLING, A. et al. Identification of Activated FXI as the Major Biochemical Root Cause in IVIG Batches Associated with Thromboembolic Events. Analytical and Experimental Approaches Resulting in Corrective and Preventive Measures Implemented into the Octagam® Manufacturing Process. WebmedCentral Immunotherapy, v. 2, n 6, p. WMC002002, 2011.

ROEMISCH, J.; ZAPFL, C.; ZOECHLING, A.; POCK, K.; Comparison of Thrombin Generation Assay (TGA) and Non-Activated Partial Thromboplastin Time (NAPTT) for the Assessment of Enhanced Procoagulant Activity in Immunoglobulin Solutions. WebmedCentral, immunotherapy, v. 3, n. 4, p. WMC003247, 2012.

ROITT, I.; BROSTOFF, J.; MALE, D. Imunologia. 6ª ed. São Paulo: Manole, 2003. $481 \mathrm{p}$.

SANTOS, G. R. et al. Structural and functional analyses of bovine and porcine intestinal heparins confirm they are different drugs. Drug Discovery Today, Jul 2014. ISSN 1878-5832. Disponível em:

< http://www.ncbi.nlm.nih.gov/pubmed/25019497 >.

SCHALLER, J. et al. Human blood plasma proteins: structure and function. England: John Wiley \& Sons Ltd, 2008. 525 p.

SCOTT, C. F.; SCHAPIRA, M.; COLMAN, R.W. Effect of heparin on the inactivation rate of human factor Xla by antithrombin-III. Blood, v. 60, p. 940-947, 1982a. 
SCOTT, C. F.; SCHAPIRA, M.; JAMES, H. L. et al. Inactivation of factor Xla by plasma protease inhibitors: predominant role of alpha 1-protease inhibitor and protective effect of high molecular weight kininogen. Journal of Clinical Investigation, v. 69, p. 844-852, 1982b.

SCOTT, C. F.; SINHA, D.; SEAMAN, F. S.. et al. Amidolytic assay of human factor XI in plasma: comparison with a coagulant assay and a new rapid radioimmunoassay. Blood, v. 63, p. 42-50, 1984.

SOARES. B. M. Política de hemoderivados no brasil: desafios e perspectivas. 90 f. Dissertação (Mestrado em Desenvolvimento Sustentável) - Centro de Desenvolvimento Sustentável, Universidade de Brasília, Brasília, 2002.

STIEHM. E. R.; KELLER. M. A.; VYAS. G. N. Preparation and use of therapeutic antibodies primarily of human origin. Biologicals, v. 36, p 363-374, 2008.

WOlBeRG, A. S.; KON, R. H.; MONROE, D. M. Factor XI Is a Contaminant in Intravenous Immunoglobulin Preparations. American Journal of Hematology, v.65, p. $34-40,2000$.

WU, Y. W.; CHAMPAGNE, J.; TOUEILLE, M.; GANTIER, R.; BURNOUF, T. Dedicated removal of immunoglobulin (Ig)A, IgM, and Factor ( $F)$ XI/activated FXI from human plasma IgG. Transfusion, v. 1, n. 54, p. 169-178, 2014.

ZHAO, M.; ABDEL-RAZEK, T.; SUN, M. et al. Characterization of a Heparin Biding Site on the Heavy Chain of Factor XI. Journal of Biological Chemistry, v. 273, n. 47, p. 31153-31159, 1998.

HEMOBRÁS. Empresa brasileira de Hemoderivados e biotecnologia.Corpo editorial. Disponível em: < http://www.hemobras.gov.br/site/conteudo/index.asp $>$

MARKETING RESEARCH BUREAU. Corpo editorial. Disponível em: $<$ <ttp://marketingresearchbureau.com/> 
World Health Organization. Corpo editorial. Disponível em:

<http://www.who.int/medicines/publications/essentialmedicines/en/index.html> 